\title{
CAPITAL ACCOUNT POLICIES IN EMERGING ASIAN ECONOMIES: ARE THEY EFFECTIVE IN THE 2000s?
}

Juthathip Jongwanich

NO. 578

April 2019
ADB ECONOMICS WORKING PAPER SERIES 


\section{Capital Account Policies in Emerging Asian Economies: Are They Effective in the 2000s?}

Juthathip Jongwanich

No. 578 | April 2019
Juthathip Jongwanich (juthathip@econ.tu.ac.th) is associate professor at the Faculty of Economics, Thammasat University.

The author thanks Joshua Aizenman, Arief Ramayandi, Hsiao Chink Tang, and the participants at the workshop on the Asian Development Outlook 2018 Update theme chapter Maintaining Macroeconomic Stability in the Current Global Environment on 30-31 May 2018 in Manila for their suggestions and comments. The author also thanks Sornsawan Sailamai for excellent research assistance. 
(C) 2019 Asian Development Bank 6 ADB Avenue, Mandaluyong City, 1550 Metro Manila, Philippines

Tel +632632 4444; Fax +6326362444

www.adb.org

Some rights reserved. Published in 2019.

ISSN 2313-6537 (print), 2313-6545 (electronic)

Publication Stock No. WPS190124-2

DOI: http://dx.doi.org/10.22617/WPS190124-2

The views expressed in this publication are those of the authors and do not necessarily reflect the views and policies of the Asian Development Bank (ADB) or its Board of Governors or the governments they represent.

ADB does not guarantee the accuracy of the data included in this publication and accepts no responsibility for any consequence of their use. The mention of specific companies or products of manufacturers does not imply that they are endorsed or recommended by ADB in preference to others of a similar nature that are not mentioned.

By making any designation of or reference to a particular territory or geographic area, or by using the term "country" in this document, $A D B$ does not intend to make any judgments as to the legal or other status of any territory or area.

This work is available under the Creative Commons Attribution 3.0 IGO license (CC BY 3.0 IGO)

https://creativecommons.org/licenses/by/3.o/igo/. By using the content of this publication, you agree to be bound by the terms of this license. For attribution, translations, adaptations, and permissions, please read the provisions and terms of use at https://www.adb.org/terms-use\#openaccess.

This CC license does not apply to non-ADB copyright materials in this publication. If the material is attributed to another source, please contact the copyright owner or publisher of that source for permission to reproduce it. $\mathrm{ADB}$ cannot be held liable for any claims that arise as a result of your use of the material.

Please contact pubsmarketing@adb.org if you have questions or comments with respect to content, or if you wish to obtain copyright permission for your intended use that does not fall within these terms, or for permission to use the ADB logo.

Corrigenda to ADB publications may be found at http://www.adb.org/publications/corrigenda.

Notes:

In this publication, “\$” refers to United States dollars.

ADB recognizes "China" as the People's Republic of China and "Korea" as the Republic of Korea.

The ADB Economics Working Paper Series presents data, information, and/or findings from ongoing research and studies to encourage exchange of ideas and to elicit comment and feedback about development issues in Asia and the Pacific. Since papers in this series are intended for quick and easy dissemination, the content may or may not be fully edited and may later be modified for final publication. 


\section{CONTENTS}

TABLES AND FIGURES

ABSTRACT $v$ V

$\begin{array}{ll}\text { I. INTRODUCTION } & 1\end{array}$

II. LITERATURE REVIEW 2

III. CAPITAL INFLOWS AND THE CAPITAL CONTROL INDEX IN EMERGING ASIA 5

A. $\quad$ Trends and Patterns in Capital Flows 5

B. Capital Account Policies in Emerging Asian Countries since 2000

IV. METHODOLOGY AND ECONOMETRIC PROCEDURE

A. Methodology $\quad 12$

B. Econometric Procedure 23

V. RESULTS 24

A. $\quad$ Effectiveness of Capital Account Policy on Volume of Capital Flows 24

B. Effectiveness of Capital Controls on Composition Changes 39

C. Effectiveness of Capital Controls: Relieving Pressure on Real Exchange Rates 41

D. Effectiveness of Capital Controls: Monetary Policy Independence 44

VI. $\quad$ CONCLUSIONS AND POLICY IMPLICATIONS

$\begin{array}{ll}\text { REFERENCES } & 49\end{array}$ 


\section{TABLES AND FIGURES}

\section{TABLES}

$1 \quad$ Variable Measurements and Data Sources for Generalized Method of Moments Estimators 18

$2 \quad$ Summary of Variables for Generalized Method of Moments Estimators

3 Effectiveness of Capital Controls on Direct Investment Flows 26

4 Effectiveness of Capital Controls on Equity Flows 29

$5 \quad$ Effectiveness of Capital Controls on Debt Security Flows 33

6 Effectiveness of Capital Controls on Other Investment Flows 36

$7 \quad$ Effectiveness of Capital Controls: Composition Changes toward Direct Investment $\quad 40$

8 Effectiveness of Capital Controls: Real Exchange Rate 41

$9 \quad$ Effectiveness of Capital Controls: Monetary Policy Independence 45

\section{FIGURES}

$1 \quad$ Capital Flows to Emerging Asian Economies, 2000-2017

2 Capital Restriction Indices for Emerging Asian Economies, 2000-2016 


\begin{abstract}
This paper examines the effectiveness of capital account policy in terms of its ability to affect the volume and composition of capital flows, relieve pressures on real exchange rates, and foster monetary policy independence. Ten emerging Asian economies are used as case studies to assess the effectiveness of capital account policy during 2000-2015. The results suggest that some types of capital controls are effective in reducing the volume of capital flows and pressure on real exchange rates. The choice of exchange rate regime matters in terms of the effectiveness of capital controls for fostering monetary policy independence. Although some types of capital controls are effective in creating macroeconomic stability, implementing capital account policy needs to be undertaken with caution. This is because substitution or complementarity among capital controls is evident, both within and across countries in the region. It seems that strong economic fundamentals are more important than capital account policy for changing the composition of capital inflows toward more stable and long-term flows.
\end{abstract}

Keywords: capital flows, capital restrictions, emerging Asia

JEL codes: F32, F31, O53 


\section{INTRODUCTION}

The debate on the use of capital account policies as a part of the toolbox to ensure macroeconomic stability has been revived in the new millennium. 'This is not surprising given the 1997-1998 Asian financial crisis and the continuing challenges facing the global economic environment, especially those spawned by the 2008 global financial crisis. An argument for using capital account policies is that welfare gains can be realized if capital is mobile internationally. Another is that greater financial integration allows for diversifying country-specific income risks. Consumption risks can be efficiently shared, and the marginal utility of consumption equalized across countries (Obstfeld 1994). Capitalscarce countries can borrow from abroad at lower rates to invest and consume more-and from the increased income, pay back the interest on international borrowing. Capital-rich countries, meanwhile, can potentially realize the highest returns by lending their savings internationally.

An argument against using capital account policies is that liberalizing trade in financial assets is not the same as liberalizing trade in goods and, more importantly, that the gains from unfettered trade in financial assets are not obvious (Bhagwati 1998). The contingent nature of a financial contract means there is no guarantee that countries borrowing from abroad will be able to repay their loans if, for example, the borrowed funds went primarily into consumption rather than investment, and that no increase in future output was forthcoming. Thus, critics of capital account liberalization argue that countries should have a limited degree of financial openness and integration in global financial markets to shield them from external shocks, including speculation, financial instability, and extreme fluctuations in exchange rates (Krugman 1999, Stiglitz 2002, Rodrik 2006). It is argued that the judicious use of capital controls, either as stand-alone tools or in combination with other macro policy initiatives, can be used to insulate countries from external economic and financial shocks. The International Monetary Fund (IMF) itself now appears to be taking a more nuanced position on capital controls, agreeing that there are indeed conditions under which controls may legitimately be used by policy makers to manage capital inflows, in addition to prudential and macroeconomic policy measures (Ostry et al. 2010, 5).

Critics who question the effectiveness of capital account policies for achieving macroeconomic stability remain vocal. They argue in particular that these policies, especially capital controls, are unlikely to cushion economies against the volatility and unpredictability inherent in capital movements given the difficulties involved in their implementation. A big doubt on the effectiveness of capital controls is the apparently ample scope for avoiding and evading them (Ariyoshi et al. 2000; Engel 2016). The argument here is that the more extensive trade and investment links are, the more difficult and costlier it will be to control capital account transactions, because of the multiplication in the number of arbitrage possibilities that arise during normal business dealings.

Regardless of the arguments on both sides, policy makers in many countries, including in Asia, continue to use capital account policies in one form or another. From 2002, foreign bank flows into Asia turned to net inflows from outflows, and both portfolio equity flows and carry trades accelerated and became more volatile and sensitive to developments in global equity markets. A number of emerging economies experienced large capital inflows and sharp currency appreciation, especially from mid-2006 to mid-2008 and even after the global financial crisis. These developments have reawakened interest in capital controls. For example, in September 2006, restrictions were imposed on the ability of foreign bank branches in the People's Republic of China (PRC) to borrow United States

\footnotetext{
Note that since the global financial crisis, the term capital flow management measures is often used to refer to capital controls and capital account policies (for example, Forbes, Fratzscher, and Straub 2015; and IMF 2017).
} 
(US) dollars abroad to fund dollar assets in the country. The PRC then raised bank reserve requirements with dollar deposits at the People's Bank of China, the central bank. An unremunerated reserve requirement on fixed income flows was introduced in Thailand in September 2006 after unsuccessful measures to limit the buildup of nonresident holdings of baht accounts implemented in 2003. In the Republic of Korea, a so-called macroprudential stability levy policy was implemented in 2011 on the nondeposit foreign liabilities of financial institutions. As well as capital inflow policies, policy makers in Asia have, since 2002, responded to large capital inflows by liberalizing capital outflows. These efforts have been stepped up in India, the PRC, the Philippines, the Republic of Korea, and Thailand (McCauley 2008, Jongwanich 2017). Interestingly, the PRC, in 2017, introduced capital outflow restrictions to prevent huge outflows from residents and to conserve foreign exchange reserves.

A number of studies examine the effectiveness of capital account policies, but their findings are mixed and vary according to the countries and periods covered (see, for example, Van der Laan, Cunha, and Lélis 2017; You, Kim, and Ren 2014; Kim and Yang 2012; and Edwards 2007). Despite the mixed empirical evidence, capital account policies are still being used worldwide. It is against this backdrop that this paper systematically examines the effectiveness of capital account policies in emerging Asia during 2000-2015. ${ }^{2}$ Their effectiveness is examined from four perspectives: (i) their ability to affect the volume of capital flows, (ii) their ability to affect the composition of capital inflows toward direct investment inflows, (iii) their ability to redress pressure on real exchange rate appreciation, and (iv) their ability to foster increased monetary independence. To clearly examine the effectiveness of capital account policies, this paper disaggregates capital flows and capital account policies by type of asset class, and between inflows and outflows. Asymmetric effects, in which the effect of tightening capital controls may be different from loosening them, is examined along with the possibility of a substitution or complementarity effect among capital controls within and across countries in emerging Asia. The latter possibility is called capital flow deflection in Forbes et al. (2016) and Giordani et al. (2017).

\section{LITERATURE REVIEW}

Capital account policy is normally used to achieve the following objectives: (i) to change the volume and composition of capital flows, (ii) to relieve pressure on rising real exchange rates and their fluctuations, (ii) to foster increased monetary independence, and (iv) as a tool to help prevent financial crises (Magud, Reinhart, and Rogoff 2011; Magud and Reinhart 2007).

Capital controls that involve restrictions imposed on cross-border capital flows can be broadly classified as either administrative or market-based controls (Ariyoshi et al. 2000). ${ }^{3}$ Administrative controls curb capital movements through outright prohibition, using an approval procedure and imposing explicit quantitative restrictions. Most administrative control measures try to directly affect the volume of cross-border financial transactions. Market-based controls restrict capital by introducing additional costs associated with cross-border financial transactions. Several forms of capital controls belong to this category, including explicit taxes on cross-border financial flows (Tobin tax); implicit taxation in the form of noninterest-bearing compulsory reserve requirements (that is,

2 Emerging Asia comprises Hong Kong, China; India; Indonesia; Malaysia; the Philippines; the PRC; the Republic of Korea; Singapore; Thailand; and Viet Nam.

3 Capital controls can also be classified as direct and indirect (Ariyoshi et al. 2000). In some studies-for example, Neely (1999) - control measures are classified by quantity and price. The variables in this classification seem to be comparable since most administrative controls are direct and quantity based, while market-based measures are mostly indirect and price based. 
unremunerated reserve requirements); and two-tier or multiple exchange rate systems or other indirect prudential regulations (for example, reporting requirements for specific transactions). Depending on the type of market-based controls, these measures can affect only the price of capital or both price and volume. Capital flow management refers to measures designed to limit capital flows; they encompass measures that discriminate on the basis of residency and those that do not (IMF 2017). When a capital flow management measure is designed to limit capital inflows to address systemic financial risk stemming from these flows, it is also considered to be a macroprudential measure.

Capital controls can be introduced to restrict inflows and outflows-or both simultaneously. The justification behind imposing controls on these forms of capital is slightly different, however. Controls on inflows are mostly introduced during booms to restrict excessive and volatile capital movements. Controls on outflows are mostly imposed during bust cycles to limit downward pressure on domestic currencies, and to mitigate any depletion of foreign exchange reserves. During normal times, controls are mainly done to preserve savings for domestic investment. Instead of imposing controls on capital inflows, easing restrictions on outflows can be another way to help redress the adverse impact of "speculative" capital inflows.

Evidence in the literature is mixed in terms of the effectiveness of capital account policies. Some empirical studies show the efficacy of capital controls in helping reach some of the objectives of introducing capital controls. Cardoso and Goldfajn (1998), examining the effectiveness of capital control policies in Brazil during 1988-1995 using a vector autoregression (VAR) model, showed these restrictions had only a temporary impact on changing the level and composition of capital flows, but led to no sustained impact in the long term. Van der Laan, Cunha, and Lélis (2017), using univariate structural models, examined the impact of Brazil's tax on external capital flows using monthly data over 2007-2017 and found it was effective in reducing capital inflows. You, Kim, and Ren (2014) examined the effectiveness of capital controls in fostering monetary independence using a panel dataset for 88 countries during 1995-2010. The results show that capital controls help foster monetary policy independence. Not all types of capital controls are effective. Restrictions on equity, collective investment, and direct investment seem to be more powerful than those on bonds and financial credit. And as You, Kim, and Ren (2014) found, constraints on inflows appear to be more powerful than those on outflows. The choice of exchange rate regime also matters for the effectiveness of capital controls. A pegged exchange rate regime with capital mobility reduces monetary independence, but when capital controls are used, a country gains more monetary policy independence. Tamirisa (1999), applying an error correction model on capital flow data for Malaysia during the 1990s, showed that the effectiveness of capital account policies varied among asset classes. Controls on portfolio inflows helped Malaysia to raise interest rates, but restrictions on outflows caused interest rates to decline. Restrictions on international ringgit transactions had an insignificant impact on interest rates. All capital control policies imposed did not have any significant effect on exchange rate movements in Malaysia.

While some studies hold that capital controls can be effective, others argue the opposite. Some of the latter studies argue that capital controls tend to be ineffective in achieving the objectives just described. Edwards (1999), reviewing the effectiveness of capital controls in Chile, found that those introduced from 1991 to 1998 had a negligible impact on interest rates. The author found that while capital controls helped to reduce the instability of Chile's stock market, they were unable to reduce financial instability. Capital controls were particularly powerless in protecting the country from the effects of the Asian financial crisis. Edwards (2007), using a large multicountry dataset for 19702004 , showed that capital controls played only a small role in reducing the probability of an abrupt contraction of net capital inflows. Instead, macroeconomic stability and strong banking supervision 
tended to be more effective in avoiding abrupt shifts in capital currents. Jittrapanun and Prasartset (2009) found an insignificant relationship between the capital control policy introduced in Thailand during the 2000s and the volume of capital inflows, though the controls tended to engender progress in the right direction in effecting capital inflows, especially portfolio investments.

Edison and Reinhart (2001), examining capital control policy in Brazil, Malaysia, and Thailand in the late 1990s using the principal component analysis of VAR models, found that capital controls were ineffective in Brazil and Thailand but not in Malaysia. Their explanation for the different outcomes involved the role of country-specific factors and the particular capital control measures imposed. Kim and Yang (2012) found that capital account policies introduced during 1990-2010 in the Republic of Korea were ineffective in influencing the amount of capital flows. But they did show that capital controls were effective in changing the composition of these flows. They also found that the volatility of capital flows and exchange rates in the Republic of Korea were higher during the period of liberalized capital accounts, especially in the 1990s.

Critics of capital controls argue that they are unlikely to cushion economies against the volatility and unpredictability inherent in capital flows, given the difficulties in implementing these restrictions. A major doubt on the effectiveness of capital controls relates to the presumably ample scope for avoidance and evasion, which can negate the expected monetary policy autonomy (Hale 1998; Edwards 1999). The general argument here is that the more extensive trade and investment links are, the harder and costlier it is to control capital account transactions. This is because of the multiple number of arbitrage possibilities arising in the course of normal business dealings.

Interestingly, recent studies on the effectiveness of capital account restrictions raise the concept of capital deflection. Here, capital inflow controls imposed by one country can deflect capital to other countries and markets, and may induce a policy response by affected countries or induce spillover impacts on other countries. The idea of capital flow deflection reflects the same concept of trade deflection in Bown and Crowley (2007). Forbes et al. (2016) examined the impact of Brazil's tax on portfolio inflows into the country, and the indirect effects of these controls on other countries during 2006-2013. For this, they used the dataset on international portfolio flows and holdings compiled by the Emerging Portfolio Fund Research; this has data on daily, weekly, and monthly flows for more than 16,000 equity and 8,000 bond funds. The results show that Brazil's tax on foreign investment in bonds caused a significant decline in their portfolio allocations to the country in both bonds and equities. A similar decline is also evident in countries that are viewed as more likely to impose capital controls. By contrast, flows increase to other countries, especially those with large exposures to the PRC, and these include other East Asian countries. The authors argue that much of the effect of capital controls on portfolio allocation appears to occur through signaling, rather than through the direct cost of the controls.

Giordani et al. (2017) built a two-period model for capital controls to show flow deflection. The model was tested on 78 less industrialized countries and emerging markets during 1995-2009, and a dynamic panel data model was applied. A de jure restrictiveness index of capital flows, as used by Schindler (2009), was applied. The results show strong evidence of capital flow deflection, especially to countries with similar economic characteristics. But they do not find policy responses from these countries. All in all, evidence from the studies in this literature review shows that the effectiveness of capital account policies is mixed, though many countries use capital controls as part of their macroprudential policies. Even the IMF acknowledges that there are conditions under which capital controls may legitimately be used by policy makers to manage capital inflows, in addition to both prudential and macroeconomic policy measures (Ostry et al. 2010). 


\section{CAPITAL INFLOWS AND THE CAPITAL CONTROL INDEX IN EMERGING ASIA}

\section{A. Trends and Patterns in Capital Flows}

After the Asian financial crisis, capital inflows rose again in Asia from 2002 until the subprime mortgage crisis of late 2008. The rise in these inflows was faster than it had been in the early 1990s (Figure 1). Foreign direct investment (FDI) is still a major part of capital channeling into Asia, accounting for over $40 \%$ of the region's total capital inflows. Asia's recovery from the financial crisis and improvements in the investment climate helped attract increased FDI into the region. The cross-border dispersion of component production and assembly within vertically integrated production processes (so-called, international product fragmentation) also became an important feature of the structural interdependence of the world economy. However, service links, especially accessibility to other Asian countries, tend to promote vertical FDI into Asia, particularly in East Asia.

For emerging Asia as a whole, portfolio investment increased from 2002 to 2007, with the biggest contribution coming from equity investments. Liberalized participation for nonresident investors, and the broadening and deepening of financial markets in the countries of the Association of Southeast Asian Nations, helped attract portfolio investments. Stock prices and market capitalization across emerging Asia rose substantially during this period. The smaller contribution of debt securities in the region was because of still underdeveloped local currency bond markets, where market capitalization (both public and private) was far lower than in industrialized countries (Jongwanich 2017). But policy initiatives developed and implemented to promote local currency bond markets have resulted in increased inflows of debt securities. Other investment inflows, mostly bank loans, were highly volatile and accelerated again during 2006-2007, especially in India, the PRC, the Republic of Korea, and Singapore in response to positive interest rate differentials and expected exchange rate appreciation.

FDI and non-FDI capital outflows became increasingly important for the region during 20022007, and other investment outflows (bank loans) increased substantially in this period. Hong Kong, China; the PRC; and Thailand were the key overseas investors operating within the realm of this type of capital outflow. Portfolio investment, especially equity investments, also grew rapidly, especially during 2006-2007. Apart from Hong Kong, China; the Republic of Korea; and Singapore, equity outflows increased substantially in the PRC and Thailand during these years. Economic recovery, the recycling of huge foreign exchange reserves, and the liberalization of capital outflows were the main factors supporting portfolio and bank loan outflows.

Capital inflows in emerging Asia were interrupted again in 2008 by the global financial crisis triggering a drop in capital flows that was more dramatic than during the Asian financial crisis. Portfolio and other investment inflows contributed substantially to this decline and became outflows during the global financial crisis. Although FDI inflows and outflows declined in all emerging Asian countries, they were nevertheless more resilient to the global slowdown than other forms of capital flows. Capital inflows rose again in the region after 2009 and this continued into 2013. Over this period, FDI still dominated the movement of capital inflows to the region - that is, about $40 \%$ of total capital inflows, the same proportion during 2002-2007-followed by portfolio and other investments. FDI dominated capital inflows in Indonesia, the Philippines, the PRC, Thailand, and Viet Nam. In the Philippines, in 2010, other investment inflows and debt security inflows tended to have a higher proportion in total

inflows than other types of capital, but FDI inflows dominated after 2013. In Hong Kong, China; 
Malaysia; and the Republic of Korea, portfolio investments, especially equity investments, were the biggest component of capital inflows. The rise in capital inflows during 2009-2013 was because of a series of monetary policy easing measures in advanced economies and the global rebalancing of portfolio flows. In addition, interest rates in many emerging markets were still relatively high, while resilience to the global financial crisis attracted capital flows into emerging Asian markets.

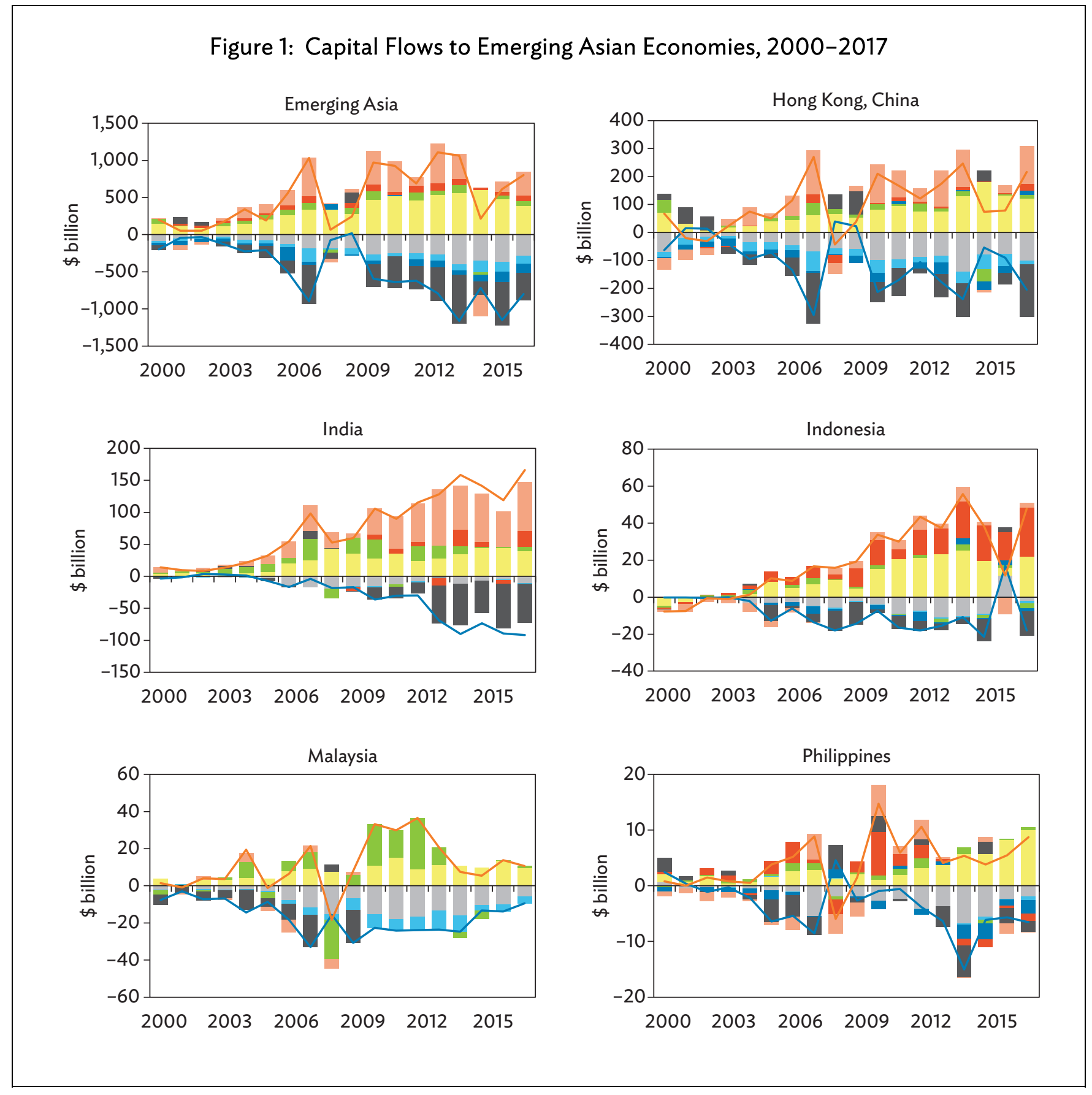


Figure 1 continued

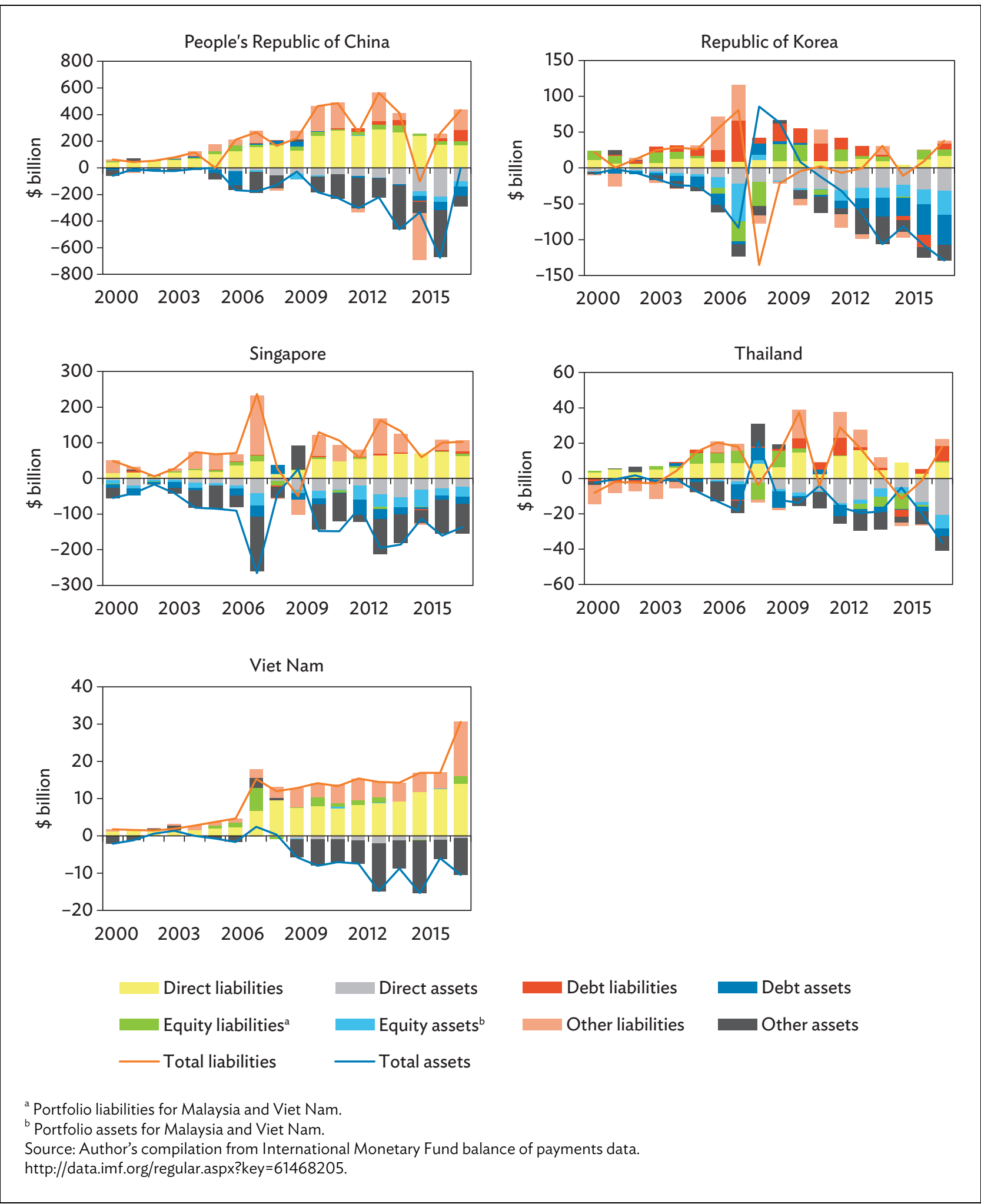


Capital inflows to the region declined during 2013-2015, mostly from other investments and portfolio flows, both in equity and debt securities. The Philippines and Viet Nam were the two exceptions: capital inflows were fairly stable in these countries because of a continued rise in FDI. The decline in capital inflows elsewhere in the region might have been caused by worries over rising interest rates; protectionist rhetoric in developed countries, particularly in the US; and concerns over the economic slowdown in the PRC. In Thailand and some other countries, heightened political uncertainty resulted in declining capital inflows. The PRC, however, continued on a moderate growth path, causing capital inflows, especially other investment inflows, to rebound across the region during 2016-2017. Interestingly, while capital outflows from residents in other countries continued to increase, along with the recovery in capital inflows, outflows from the PRC in 2017 declined sharply (Figure 1). This may have been because of capital outflow restrictions, especially on other investment outflows, imposed to prevent a huge drain from residents and to conserve forex reserves.

\section{B. Capital Account Policies in Emerging Asian Countries since 2000}

Capital account policies in emerging Asian economies since 2000 have been heterogeneous. Singapore and Hong Kong, China have practically liberalized their capital accounts in keeping with their financial center status. India and the PRC have maintained a high degree of capital account restrictions, compared with other countries in the region. Many emerging Asian economies tightened capital inflow restrictions and liberalized capital outflows after the global financial crisis and in the early 2000s when capital inflows surged into Asia. From 2013, amid worries over interest rates starting to rise, capital outflow restrictions were introduced in some countries in the region.

India's first policy response to rising capital inflows after the Asian financial crisis was to intervene in the foreign exchange market and, instead of capital restrictions, conduct sterilization. After 2006, restrictions on inflows were tightened and those on outflows were eased to curb a surge in capital inflows. Interest rate ceilings on foreign borrowing in India were reduced in 2006-2007 to discourage foreigners from lending to nonresident Indians and for external commercial borrowing. Companies taking out more than $\$ 20$ million in external commercial borrowings were stopped from remitting funds in 2007. In the same year, however, Indian firms were permitted to invest in overseas joint ventures or in wholly owned subsidiaries up to $400 \%$ of their net worth, and the aggregate ceiling for overseas investment by mutual funds was increased. In 2014, the Reserve Bank of India tightened capital outflow restrictions to help staunch capital outflows and because of the rupee's plunge. The central bank, among other actions, cut the amount that firms could invest overseas from $400 \%$ to only $100 \%$ of their net worth.

After the PRC joined the World Trade Organization in 2001, its focus on capital liberalization was on balancing inflows and outflows to achieve a stability of the country's external position. The resulting Go Out policy was launched in 2001 to encourage FDI outflows and promote FDI inflows. A year later the qualified foreign institutional investor (QFII) scheme was launched to allow these investors to buy renminbi-denominated domestic securities. From 2004, measures to discourage capital inflows were introduced to curb speculative non-FDI inflows. Among these measures were limits on the overseas borrowing of domestic banks and PRC-based foreign companies introduced in 2004, a restriction on foreigners buying real estate in the PRC in 2006, and upper limits on the maturity of import finance being shortened from 120 days to 90 days in 2009.

During 2013-2015, liberalization resumed in the PRC for capital inflows and outflows. For example, the overall investment limit for QFIls was increased to $\$ 150$ billion from $\$ 80$ billion over this period. Residents were able to make outward direct investments without approval by the relevant 
authorities as long as these investments were registered with the authorities. The exception was for investments involving sensitive countries, regions, and industries. Before this, external direct investments were subject to registration or approval by the relevant authorities. It should be noted that in the PRC, capital account transactions still require the approval of the State Administration of Foreign Exchange. Capital outflow restrictions were tightened in 2015 to prevent outflows from residents and to conserve foreign exchange reserves. As part of these measures, individuals were allowed in 2017 to withdraw only a maximum of CNY100,000 a year from a single account. Before 2017, an annual limit of CNY100,000 on overseas withdrawals was set for a single bank card.

In the Republic of Korea, in response to a rapid increase in capital inflows, the Bank of Korea liberalized its capital outflow policies during 2000-2009 (Kim and Yang 2012). For example, residents were allowed to buy real estate overseas, and 3-year tax exemptions were applied on capital gains from overseas equity investments. In 2009, in response to concerns about the lack of domestic foreign exchange liquidity, tax exemptions of $14 \%$ were granted on capital gains and $20 \%$ on interest income on foreign investors' bond investments. During 2010-2014, however, capital flow policy was tightened. In 2010, limits were put on the foreign exchange derivative positions of banks in which the derivativesposition ratio was $50 \%$ of the equity capital of local banks and $250 \%$ for foreign banks. The ratio was reduced for local banks to $40 \%$ in 2011 and 30\% in 2013, and to 200\% and 150\% for foreign banks in the same period. A macroprudential stability levy policy was implemented on nondeposit foreign liabilities of financial institutions in 2011. A tax on capital gains and interest income from foreign investors' bond investments was revived in 2011. After 2015, the government started to loosen capital restrictions. In 2016, the foreign exchange derivatives-position ratio of local banks was raised to $40 \%$ and to $200 \%$ for foreign banks.

In Thailand, capital inflow restrictions were introduced in 2003 that principally concerned the continued influx of debt securities and other investment inflows. Because of short-term capital inflows and a noticeable appreciation in the baht in 2006, additional restrictions were put on capital inflows, including unremunerated reserve requirements. These were gradually relaxed in 2007 and the unremunerated reserve requirements were lifted in 2008. Several policy measures relaxing restrictions on capital outflows were taken after 2003; these applied to FDI and portfolio investments to offer investment opportunities for residents. In 2012, the Bank of Thailand, the central bank, announced its Capital Account Liberalization Master Plan to encourage residents to diversify their investments abroad; the plan also relaxed measures aimed at preventing speculation in the baht by nonresidents. The relaxation measures continued in 2017. Among the measures was a provision aimed at removing the limit on direct investments by residents, and one that expanded the outstanding limit of domestic financial institutions. The latter measure provided baht liquidity to and borrowing from nonresidents for transactions done without underlying trade and investment to B500 million in 2012 and then to B600 million in 2017.

In Malaysia, substantial progress on capital account liberalization for inflows and outflows has been made since 2000. This is especially so after 2005 when the ringgit peg to the US dollar was abolished in favor of a managed floating exchange rate system; this expanded both investment limits and bases. In 2007, residents were free to invest abroad using foreign currency funds sourced from overseas. Residents with ringgit borrowings converted to foreign currency were free to invest abroad up to the equivalent of RM50 million and up to RM1 million for resident individuals. From 2013, nonresidents were allowed to issue foreign currency-denominated securities. But nonresidents needed approval from the central bank to issue ringgit-denominated securities or offer shares for sale in Malaysia. 
In the Philippines, capital outflow restrictions on nonresidents to reduce capital inflows and liberalize outflows for residents were implemented by the Philippine Central Bank for the period 2002-2007 during a surge in capital inflows (Gonzalez 2008). The measures included raising the amount of dollars that domestic banks could hold overnight (the dollar overbought position) to $20 \%$ of unimpaired capital with an absolute limit of $\$ 50$ million. Before these measures, domestic banks were allowed to hold dollars up to an equivalent of $2.5 \%$ of their unimpaired capital. The central bank imposed a cap under which local banks could sell dollars against the peso (the oversold position) at a rate of up to $20 \%$ of unimpaired capital; there was hitherto no cap. The central bank also expanded the amount that residents could invest overseas without its approval from $\$ 6$ million to $\$ 12$ million, and increased the amount of foreign exchange that residents could buy without documentation to $\$ 10,000$ from $\$ 5,000$. In 2016, capital outflow restrictions were further liberalized, with the amount of dollars that residents and companies could buy for legitimate transactions from banks raised from $\$ 120,000$ to $\$ 500,000$, and to $\$ 1$ million, respectively.

Viet Nam has seen a new wave of market-oriented reforms since 2000 after these virtually stalled during the Asian financial crisis. The country's FDI law was amended in 2000 to allow foreigninvested enterprises and parties to enter business cooperation contracts to change their mode of investment, and to split and merge freely. The withholding tax on profit transfers was also reduced (Menon 2009). In 2007, legislation was passed to allow mergers and acquisitions to be a channel of FDI in Viet Nam. For this purpose, two securities trading centers were set up: the Ho Chi Minh City Securities Trading Center in 2000 and Hanoi Securities Trading Center in 2005. The equity shares of listed companies that foreign investors can hold was increased from 20\% in 2000 to 30\% in 2003 and to $49 \%$ in 2005 . Further liberalization in the banking sector included permitting foreign credit institutions to set up a commercial presence in Viet Nam, including banks with 100\% foreign-owned capital. The global financial crisis, however, caused the government to tighten its supervision of risks in the financial sector. It imposed a 3\% cap on bank lending on securities at the end of 2007. In 2009, taxes on securities transactions were imposed at $0.1 \%$ on the value of each transaction (or $20 \%$ on the value of transactions at the end of a year). Quotas on the amount of investments in Viet Nam that foreign investors could make were also imposed. From 2011, under the country's World Trade Organization commitments, capital account liberalization was gradually resumed. This included allowing 100\% foreign-owned securities firms to set up branches in Viet Nam.

Indonesia veered from the trend of capital account liberalization seen in other countries in the region from the early 2000s by tightening capital restriction policies to curb capital outflows and speculation against the rupiah. In 2001, foreigners were prohibited from rupiah transactions, and forward currency transactions were reduced to $\$ 3$ million from $\$ 5$ million. ${ }^{4}$ In 2003 , Bank Indonesia, the central bank, announced that banks would have to maintain a net foreign currency position up to a maximum of $20 \%$ of their capital. In 2008 , to dampen currency speculation, buying foreign currency against rupiahs by residents and foreign investors exceeding $\$ 100,000$ had to be based on underlying transactions. Along with other Asian countries, Indonesia tightened capital inflow policies in 2009 to dampen short-term capital inflows. The central bank introduced a 1-month holding period for shortterm Bank Indonesia certificates regardless of whether they were purchased in the primary or secondary markets by domestic or foreign investors. Bank Indonesia also changed the maturity structure of these certificates from 1- to 3- and 6-month tenures, and increased the maturity range of its debt instruments to 9-12 months. Auctions for these certificates were changed from once a week to once a month.

4 Because of the very low foreign currency spreads in Singapore, some speculators who had substantial rupiah deposits could benefit from forward swaps against small day-to-day movements in the rupiah. 
Figure 2: Capital Restriction Indices for Emerging Asian Economies, 2000-2016
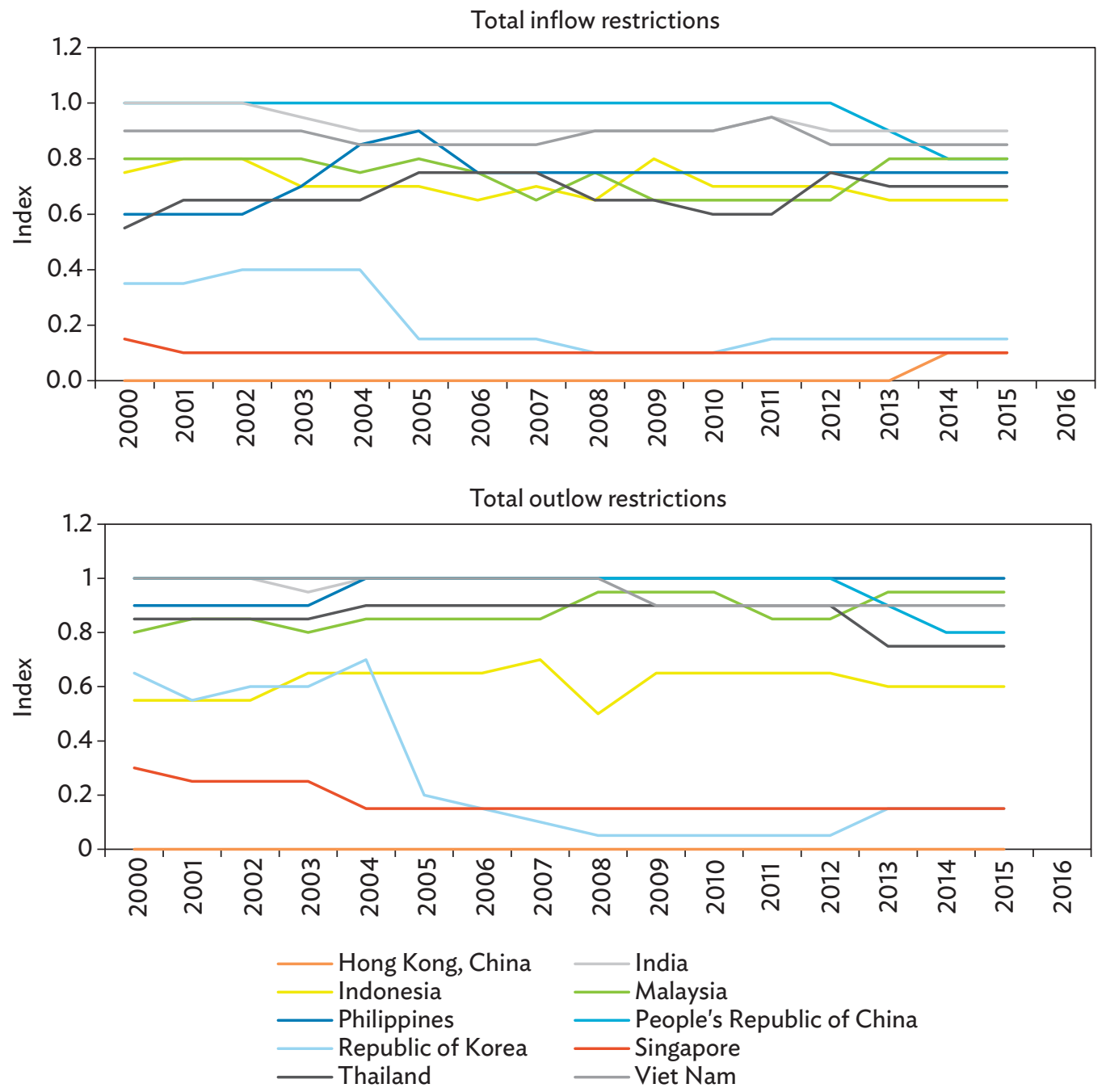

Sources: International Monetary Fund. 2000-2015. Annual Report on Exchange Arrangements and Exchange Restrictions. Washington, DC; Fernández, Andrés, Michael W. Klein, Alessandro Rebucci, Martin Schindler, and Martin Uribe. 2016. "Capital Control Measures: A New Dataset." IMF Economic Review 64 (3): 548-74.

In this paper, de jure capital account restrictions are derived from the IMF's Annual Report on Exchange Arrangements and Exchange Restrictions (Fernández et al. 2016). Capital restrictions are divided by asset category (direct investment, portfolio equity, portfolio debt, and other investment flows) and by the direction of flows (inflows and outflows). The indices are more finely gradated. For example, by using the IMF's binary capital controls dummy, which has been used in numerous studies. The indices lie between 0 and 1, from least to most regulated. Figure 2 shows the total inflow and outflow restrictions in emerging Asian economies. Consistent with their liberalization policies, Singapore and Hong Kong, China have practically liberalized their capital accounts; that is, their indices 
lie close to 0 . India and the PRC, however, have maintained a relatively high degree of capital account restrictions, and the indices to some extent reflect the direction of capital account policies in these countries. For example, the decline in capital control indices in the PRC during 2013-2015 reflects the liberalization policies discussed earlier. The increase in capital inflow indices in Thailand during 20062008 and 2011 reflects more capital restrictions on inflows, and in Viet Nam they reflect tighter capital inflow policies during 2008-2011. ${ }^{5}$

\section{METHODOLOGY AND ECONOMETRIC PROCEDURE}

\section{A. Methodology}

This section provides a baseline regression equation to examine the effectiveness of capital account policy to (i) change the volume of capital flows, (ii) change the composition of capital inflows toward direct investment, (iii) relieve pressure on rising real exchange rates, and (iv) foster increased monetary independence.

\section{Effectiveness of Capital Controls: Reducing the Volume of Capital Flows}

To clearly examine the effects of de jure restrictions on the volume of capital flows, these flows are disaggregated into inflows and outflows. ${ }^{6}$ In the balance of payments data, net purchases (capital inflows) or sales (capital outflows) by nonresidents of domestic assets are included on the liability side, and net purchases (capital outflows) or sales (capital inflows) of foreign assets by residents are on the asset side. Thus, both liabilities and assets in the balance of payments can take negative values. The negative value of liability (assets) can be considered as outflows (inflows). To derive total capital inflows and outflows in each period, the following formulation is used:

$$
\begin{aligned}
& \text { Inflows }=-\min (\text { derived flow assets }, 0)+\max (\text { derived flow liabilities, } 0) \text {, } \\
& \text { Outflows }=\max (\text { derived flow assets }, 0)-\min (\text { derived flow liabilities }, 0) .
\end{aligned}
$$

To examine the effect of de jure restrictions on the volume of capital inflows and outflows, the following baseline regression equation, using only inflows as an example, is estimated:

$$
\begin{aligned}
& \left(\frac{C F I_{k}}{G D P}\right)_{i t}=\alpha_{o, i t}+\alpha_{1, i t} C R I_{k, i t}+X_{i t} \theta+\eta_{i}+\varepsilon_{i t}, \\
& \left(\frac{C F O_{k}}{G D P}\right)_{i t}=\alpha_{o, i t}+\alpha_{1, i t} C R O_{k, i t}+X_{i t} \theta+\eta_{i}+\varepsilon_{i t},
\end{aligned}
$$

where $\left(\mathrm{CFI}_{k} / \mathrm{GDP}\right)_{\text {it }}$ is capital inflows type $k\left(\mathrm{CFI}_{k}\right)$ to gross domestic product (GDP) in country $i$ at time $t$ (type $k$ refers to capital flows and in particular asset categories, including direct investment inflows $\left(C K I_{\text {direct }}\right)$, equity $\left(C K l_{\text {equity }}\right)$, debt securities $\left(C K I_{\text {debt }}\right)$, other inflows (including loans) $\left(C K I_{\text {other }}\right)$, and $\left(C F O_{k} / G D P\right)_{i t}$ is capital outflows type $k$.

5 There are limitations, however, to using information from the IMF's Annual Report on Exchange Arrangements and Exchange Restrictions. Because the information is rather aggregated, it fails to adequately capture changes in the frequency of either the usage or degree of changes in restrictiveness across a year.

6 This is because no significant effect is found when net inflows-both total and each type of asset-are used as dependent variables. The results are available from the author at juthathip@econ.tu.ac.th. 
$C R I_{k, t}$ and $C R O_{k, t}$ are the capital inflow and outflow restriction index for type $k$ in country $i$ at time $t$, respectively. Capital restrictions are divided by asset category (direct investment, portfolio equity, portfolio debt, and other investment flows) and by the direction of flows (inflows and outflows). The indices lie between 0 and 1, from least to most regulated.

$X_{i t}$ is a vector of control variables, chosen on the basis of an idea of external and internal factors (or push and pull factors) (Calvo, Leiderman, and Reinhart 1993; Fernandez-Arias 1996; Filer 2004). ${ }^{7}$ The control variables include (i) the growth of real GDP per capita in country $i$ ( $g d p_{\text {_ppercapita_ }} g_{i}$ ), (ii) the real interest rate differential between country $i$ and the US (r_in_diff_us $s_{i}$, (iii) nominal and real effective exchange rates (ex $x_{i}$ and reer $_{i}$ ), (iv) the ratio of domestic credit to the private sector $\left(d c_{-} g d p_{i}\right)$, and $(v)$ the ratio of stock market trade to GDP (stocktrade_gdpi ). These variables are used as proxies for (i) an economy's level of financial development; (ii) the ratio of trade to GDP as a measure of an economy's openness to trade (trade_gdp $)_{i}$; (iii) the ratio of a country's natural resource endowment $\left(n r_{i}\right)$; (iv) the Volatility Index $(V I X)$ as a proxy for external risks; and ( $v$ ) good governance in country $i$, which is proxied by data from the PRS Group's International Country Risk Guide $\left(P R S_{i}\right){ }^{8}$

$\eta_{i}$ is an unobserved country-specific fixed effect and $\varepsilon_{i t}$ the error term. Note that equation (2) is also applied for capital outflows.

Interestingly, there is a possibility of asymmetric effects if capital restrictions are imposed, whereby the effects of tighter controls may be different from those of loosening controls. To test this possibility, equation (2) is modified according to Gochoco-Bautista, Jongwanich, and Lee (2012) as follows:

$$
\begin{aligned}
& \left(\frac{C F I_{k}}{G D P}\right)_{i t}=\alpha_{o, i t}+\alpha_{1, i t} C R I_{k, i t}+\alpha_{2, i t}\left(C R I_{k, i t} \cdot D^{\text {tight }}\right)+\alpha_{3, i t}\left(C R I_{k, i t} \cdot D^{\text {loosen }}\right)+X_{i t} \theta+\eta_{i}+\varepsilon_{i t}, \\
& \left(\frac{C F O_{k}}{G D P}\right)_{i t}=\alpha_{o, i t}+\alpha_{1, i t} C R O_{k, i t}+\alpha_{2, i t}\left(C R O_{k, i t} \cdot D^{\text {tight }}\right)+\alpha_{3, i t}\left(C R O_{k, i t} \cdot D^{\text {loosen }}\right)+X_{i t} \theta+\eta_{i}+\varepsilon_{i t},
\end{aligned}
$$

where $D^{\text {tight }}$ is a dummy variable that takes on the value of 1 when capital controls are tightened from the previous period and 0 otherwise, and $D^{\text {loosen }}$ is a dummy variable that takes on the value of 1 when capital controls are loosened from the previous period and 0 otherwise. Asymmetric effects occur when either $\alpha_{2, i t}$ or $\alpha_{3, i t}$ or both are statistically significant.

\footnotetext{
7 External factors refer to economic fundamentals in capital-sending countries; internal factors are represented by the evolution of economic fundamentals in capital-receiving nations.

8 The Volatility Index is based on the S\&P 500 Index, the core index for US equities.
} 
For examining asymmetric effects, equation (1) can also be modified, as in equation (4), to show whether capital inflow (outflow) restrictions imposed on nonresidents or residents are effective. ${ }^{9}$

$$
\begin{aligned}
& \left(\frac{C F I_{k}}{G D P}\right)_{i t}=\alpha_{o, i t}+\alpha_{1, i t} C R N I_{k, i t}+\alpha_{2, i t} C R R I_{k, i t}+X_{i t} \theta+\eta_{i}+\varepsilon_{i t}, \\
& \left(\frac{C F O_{k}}{G D P}\right)_{i t}=\alpha_{o, i t}+\alpha_{1, i t} C R N O_{k, i t}+\alpha_{2, i t} C R R O_{k, i t}+X_{i t} \theta+\eta_{i}+\varepsilon_{i t},
\end{aligned}
$$

where $C R N I_{k, i t}$ and $C R N O_{k, i t}$ refer to capital inflow and outflow restrictions imposed on nonresidents, and $C R R I_{k, i t}$ and $C R R O_{k, i t}$ refer to capital inflow and outflow restrictions imposed on residents.

It is possible to have (i) effects between capital inflow and outflow controls on each asset type, (ii) substitution effects in capital account policies on each type of capital flows, and (iii) effects of capital policy imposed by other countries. Equation (2) is modified to include effects. Equation (2) is then modified in terms of specifically capital inflows to examine the three possible effects as follows:

$$
\begin{aligned}
& \left(\frac{C F I_{k}}{G D P}\right)_{i t}=\alpha_{o, i t}+\alpha_{1, i t} C R I_{k, i t}+\alpha_{2, i t} C R O_{k, i t}+X_{i t} \theta+\eta_{i}+\varepsilon_{i t}, \\
& \left(\frac{C F I_{k}}{G D P}\right)_{i t}=\alpha_{o, i t}+\alpha_{1, i t} C R I_{k, i t}+\alpha_{2, i t} C R I_{j \neq k, i t}+X_{i t} \theta+\eta_{i}+\varepsilon_{i t}, \\
& \left(\frac{C F I_{k}}{G D P}\right)_{i t}=\alpha_{o, i t}+\alpha_{1, i t} C R I_{k, i t}+\alpha_{2, i t} C R I_{k,(j \neq i) t}+X_{i t} \theta+\eta_{i}+\varepsilon_{i t},
\end{aligned}
$$

where $C R O_{k, i t}$ in equation (5) represents the capital outflow restrictions imposed on asset type $k$ of country $i$ at time $t$. $C R I_{j \neq k, i t}$ in equation (6) is capital inflow restrictions on asset type $j$ of country $i$ at time $t$. This means that for direct investment inflows, $C R I_{k, i t}$ are direct investment inflow restrictions. $C R I_{j \neq k, i t}$ are restrictions on other asset types, including equity inflow restrictions, bond inflow restrictions, and commercial and financial credit restrictions. $C R I_{k,(j \neq i) t}$ in equation (7) are capital inflows restrictions on asset type $k$ imposed by other countries. Note that equations (5), (6), and (7) are also applied on capital outflows because of possible substitution among capital outflow restrictions.

\section{Effectiveness of Capital Controls: The Changing Composition of Capital Inflows toward Direct Investment Inflows}

Because substitution effects among capital inflow controls are possible, ${ }^{10}$ examining only the effects of capital controls on the volume of each type of capital inflow would clearly prevent conclusions being drawn on the effectiveness of capital controls in changing the composition of inflows toward longerterm capital, such as FDI. To test this effectiveness, equation (2) is modified as follows:

9 Note that for direct investment and other investment flows, most restrictions on capital inflows are imposed only on nonresidents, while those for outflows are imposed only on residents. Thus, there is no separation between capital inflow and outflow restrictions on nonresidents and residents as in other type of capital flows.

10 An example of the substitution effect is that direct investment inflow restrictions could reduce equity inflows and vice versa. 


$$
\left(\frac{C F I_{\text {direct }}}{\text { Total inflows }}\right)_{\text {it }}=\alpha_{o, i t}+\alpha_{1, i t} C R I_{\text {direct, it }}+\alpha_{2, i t} C R I_{j \neq d \text { direct }, i t}+X_{i t} \theta+\eta_{i}+\varepsilon_{i t} \text {, }
$$

where $\mathrm{CFI}_{\text {direct }} /$ Total inflows is the ratio of direct investment inflows to the total inflows of country $i$ at time $t . C R I_{j \neq d i r e c t, i t}$ in equation (8) represents capital inflow restrictions by asset type other than direct investment inflow restrictions of country $i$ at time $t . X_{i t}$ is a vector of control variables, which are the same set of variables as those in equation (2).

As in the case of volume of capital inflows, the capital policies imposed by other countries may affect the composition of capital inflows. To examine this possible effect, equation (8) is modified as follows:

$$
\left(\frac{C F I_{\text {direct }}}{\text { Total inflows }}\right)_{\text {it }}=\alpha_{0, i t}+\alpha_{1, i t} C R I_{\text {direct }, i t}+\alpha_{2, i t} C R I_{\text {direct, }(j \neq i) t}+X_{i t} \theta+\eta_{i}+\varepsilon_{i t} \text {, }
$$

where $C R I_{\text {direct, }(j \neq i) t}$ is direct investment inflow restrictions of country $j$ at time $t$.

\section{Effectiveness of Capital Controls: Relieving Pressure on Real Exchange Rates}

An internal and external balance approach is used as a framework for determining real exchange rates (Edward 1989; Hinkle and Montiel 1999; Baffes, Elbadawi, and O'Connell 1999). Internal balance is a situation in which the demand for and supply of nontradable goods is equal. External balance implies reaching a steady state of change in total net foreign assets within an economy. On the basis of this framework, the determinants of the real exchange rate are as follows: ${ }^{11}$

$$
R E R_{i t}=\alpha_{\mathrm{o}}+\alpha_{1}(\mathrm{CFI} / \mathrm{GDP})_{k, i t}+\alpha_{2}(\mathrm{CFO} / \mathrm{GDP})_{k, i t}+X_{i t} \theta+\eta_{i}+\varepsilon_{i t}
$$

where $R E R_{i t}$ is the real exchange rate. Here, where an increase in this variable refers to a depreciation trend $C F I_{k, i t}$ (and $C F O_{k, i t}$ ) are capital inflows (outflows) of asset type $k$ of country $i$ at time $t$.

The control variable $\left(X_{i t}\right)$ is composed of government spending (govcon_gdp $p_{i t}$ ), productivity differentials $\left(P R O D_{i t}\right.$ ), terms of trade (tot $t_{i t}$ ), and trade policy (trade_gdp $p_{i t}$ ). Because government spending tends to be more intensive for nontradable goods, an increase in govcon_GDP induces an increase in the demand for these goods. This puts pressure on the prices of nontradable goods, resulting in an appreciation in the real exchange rate (RER), which is necessary to restore internal equilibrium. According to the Harrod-Balassa-Samuelson hypothesis, an increase in productivity differentials (that is, an improvement in the tradable sector compared with other countries), (PROD) will raise the demand for labor in the tradable sector. Under full employment conditions, labor must be drawn from the nontradable sector toward the tradable sector, and when this happens, this puts pressure on wage rates in the nontradable sector. This, in turn, causes $R E R$ to appreciate to restore the internal and external balance.

1 Jongwanich (2017) gives details of the internal and external balance approach, and real exchange rate determinants. 
Terms of trade (TOT), the ratio of export to import prices, is included to capture exogenous changes in world prices that will affect RER. TOT improvement generates an income effect, which increases domestic demand. To restore the internal and external equilibriums, nontradable prices have to increase relative to tradable ( $R E R$ appreciation) to switch demand from nontradable toward tradable goods. This effect could, however, be counterbalanced by a substitution effect. Here, demand for tradable goods increases in light of relatively lower import prices, and this leads to an overall real depreciation in the exchange rate. So in theory, the relationship between RER and TOT is ambiguous. ${ }^{12}$

A shift in a country's trade policy toward greater liberalization (OPEN) leads to an increase in demand for tradable goods. The RER is required to depreciate to switch demand from tradable goods toward nontradable goods to restore equilibrium. Hence, $R E R$ is positively related to the degree of trade liberalization.

To test the effectiveness of capital controls in relieving pressures on real exchange rate changes, equation (10) is modified as follows:

$$
\begin{aligned}
R E R_{i t} & =\alpha_{\mathrm{o}}+\alpha_{1}\left(\frac{\mathrm{CFI}}{\mathrm{GDP}}\right)_{k, i t}+\alpha_{2}\left(\frac{\mathrm{CFI}}{\mathrm{GDP}}\right)_{k, i t} \cdot \mathrm{CRI_{k,it }}+\alpha_{3}\left(\frac{\mathrm{CFO}}{\mathrm{GDP}}\right)_{k, i t}+\alpha_{4}\left(\frac{\mathrm{CFO}}{\mathrm{GDP}}\right)_{k, i t} \cdot \mathrm{CRO}_{k, i t} \\
& +X_{i t} \theta+\eta_{i}+\varepsilon_{i t}
\end{aligned}
$$

where $C R I_{k, i t}$ (and $C R O_{k, i t}$ ) are restrictions on capital inflows (outflows) of asset type $k$ of country $i$ at time $t$. The effectiveness of capital restrictions is detected when either $\alpha_{2}$ is positive and statistically significant (that is, capital inflow restrictions help to reduce pressure on real exchange rate appreciation) or $\alpha_{4}$ is negative and statistically significant (that is, capital outflow restrictions reduce pressure on RER depreciation) or both are statistically significant.

\section{Effectiveness of Capital Controls: Monetary Policy Independence}

Monetary policy independence refers to the ability of a country to set its own monetary policy independent of external influences. To test the effectiveness of capital controls in fostering monetary policy independence, the baseline equation is as follows:

$$
\mathrm{MI}_{i t}=\alpha_{\mathrm{o}}+\alpha_{1} \mathrm{CRI} I_{i t}+\alpha_{2} \mathrm{CRO}_{i t}+\alpha_{3} \mathrm{Peg}_{i t}+\alpha_{4} \mathrm{CRI} \cdot \mathrm{Peg}_{i t}+\alpha_{5} \mathrm{CRO}_{i t} \cdot \mathrm{Peg}_{i t}+X_{i t} \theta+\eta_{i}+\varepsilon_{i t},
$$

where $\mathrm{MI}_{i t}$ reflects the monetary policy independence of country $i$ at time $t$. Because monetary policy is usually conducted through interest rate manipulation, monetary policy independence here refers to the difference in interest rates between home country and base country.

$$
C R I_{i t} \text { and } C R O_{i t} \text { are total capital inflow and outflow restrictions of country } i \text { at time } t \text {. }
$$

12 Note that a body of work in the empirical literature stresses that in developing countries an improvement in terms of trade (TOT) tends to cause an appreciation in real exchange rates because the income effect generally overwhelms the substitution effect (Edwards 1989; Baffes, Elbadawi, and O'Connell 1999). 
$\mathrm{Peg}_{i \mathrm{it}}$ is the de facto fixed exchange rate regime, which includes hard and soft peg regime measures. $^{13}$

$X_{i t}$ represents control variables, which are composed of inflation (inflation), financial development (stocktrade_gdp and $d c \_g d p$ ), trade openness (trade_gdp), income (GDP per capita), degree of sterilization (bm_reserves), exchange rate (ex), and exchange rate volatility (exvolatility).

When inflation is high, central banks tend to loosen monetary independence because of domestic pressure. A loosening might also occur when a country is trying to tie its currency to lowinflation countries to tackle inflation pressures. A negative relationship between inflation and monetary independence is found in Alesina and Summers (1993); Cukierman, Webb, and Neyapti (1992); and You, Kim, and Ren 2014. Generally, a mature financial market implies effective financial integration into the world market. Thus, a country with mature financial development tends to be more exposed to international financial market shocks, thereby reducing its monetary independence. A high degree of trade openness is likely to increase exposure to foreign shocks, so that monetary independence tends to be lower.

The effects of income on monetary independence are ambiguous. On the one hand, more advanced economies are likely to adopt a flexible exchange rate regime and try to exercise their own monetary policy initiatives. On the other hand, trade and financial integration tends to be higher in more advanced economies, so that exposure to shocks may reduce monetary independence. This paper also includes degree of sterilization (bm_reserves) as another control variable, since sterilization can allow a central bank to gain more monetary independence. The exchange rate is included to control for the possibility that depreciation may induce more inflation pressure, thereby reducing monetary independence. Exchange rate volatility is also included as a control variable since monetary independence is in place when a country allows the exchange rate to be one of the variables absorbing shocks. Thus, if a country has some degree of real exchange rate fluctuation, monetary independence would be strengthened.

To examine whether capital restrictions (inflows and outflows) are more effective in fostering monetary independence in a fixed exchange rate regime, interaction terms between capital restrictions and a fixed exchange rate regime are included in equation (12). The presence of more effective capital controls with a fixed exchange rate is detected when either $\alpha_{4}$ or $\alpha_{5}$ or both are positive and significant.

The effectiveness of using capital account policy is estimated for Hong Kong, China; India; Indonesia; Malaysia; the Philippines; the PRC; the Republic of Korea; Singapore; Thailand; and Viet Nam during 2000-2015. ${ }^{14}$ Table 1 gives details on the definition and sources of the data used to estimate equations (2)-(12); Table 2 shows summary statistics of the data collected.

13 A soft peg according to the IMF's definition includes a conventional peg, stabilized arrangements, a crawling peg, crawllike arrangements, and pegged exchange rates within horizontal bands and other managed arrangements. For example, in 2016, four of the 10 emerging Asian economies covered in this paper have de facto fixed exchange rate regimes: Hong Kong, China; the PRC; Singapore; and Viet Nam.

14 Because of data availability, especially for the capital restriction data, the effectiveness of capital account policy is analyzed only until 2015. 


\section{Table 1: Variable Measurements and Data Sources for Generalized Method of Moments Estimators}

\begin{tabular}{|c|c|c|c|}
\hline Variables & & Measurements & Data Source \\
\hline$C F I / G D P$ & $\begin{array}{l}\text { Total capital inflows to gross } \\
\text { domestic product (GDP) }\end{array}$ & $\begin{array}{l}\text { Total Inflows }=-\min (\text { derived flow assets }, 0) \\
+\max (\text { derived flow liabilities }, 0)\end{array}$ & $\begin{array}{l}\text { International Monetary } \\
\text { Fund (IMF) balance of } \\
\text { payments data }\end{array}$ \\
\hline$C F I_{\text {direct }} / G D P$ & $\begin{array}{l}\text { Direct investment inflows } \\
\text { to GDP }\end{array}$ & Same as total inflows & $\begin{array}{l}\text { IMF balance of } \\
\text { payments data }\end{array}$ \\
\hline$C F I_{\text {equity }} / \mathrm{GDP}$ & Equity inflows to GDP & Same as total inflows & $\begin{array}{l}\text { IMF balance of } \\
\text { payments data }\end{array}$ \\
\hline$C F I_{\text {debt }} / G D P$ & Debt security inflows to GDP & Same as total inflows & $\begin{array}{l}\text { IMF balance of } \\
\text { payments data }\end{array}$ \\
\hline$C F I_{\text {other }} / G D P$ & $\begin{array}{l}\text { Other investment, including } \\
\text { loans, to GDP }\end{array}$ & Same as total inflows & $\begin{array}{l}\text { IMF balance of } \\
\text { payments data }\end{array}$ \\
\hline CFO/GDP & Total capital outflows to GDP & $\begin{array}{r}\text { Outflows }=\max (\text { derived flow assets }, 0) \\
-\min (\text { derived flow liabilities }, 0)\end{array}$ & $\begin{array}{l}\text { IMF balance of } \\
\text { payments data }\end{array}$ \\
\hline $\mathrm{CFO}_{\text {direct }} / \mathrm{GDP}$ & $\begin{array}{l}\text { Direct investment outflows } \\
\text { to GDP }\end{array}$ & Same as total outflows & $\begin{array}{l}\text { IMF balance of } \\
\text { payments data }\end{array}$ \\
\hline $\mathrm{CFO}_{\text {equity }} / \mathrm{GDP}$ & Equity outflows to GDP & Same as total outflows & $\begin{array}{l}\text { IMF balance of } \\
\text { payments data }\end{array}$ \\
\hline $\mathrm{CFO}_{\text {debt }} / \mathrm{GDP}$ & Debt security outflows to GDP & Same as total outflows & $\begin{array}{l}\text { IMF balance of } \\
\text { payments data }\end{array}$ \\
\hline $\mathrm{CFO}_{\text {other }} / \mathrm{GDP}$ & $\begin{array}{l}\text { Other investment outflows to } \\
\text { GDP }\end{array}$ & Same as total outflows & $\begin{array}{l}\text { IMF balance of } \\
\text { payments data }\end{array}$ \\
\hline$C R I$ & Overall inflow restrictions index & $\begin{array}{l}\text { Average of all inflow restrictions } \\
\text { (value lies between } 0 \text { to } 1 \text {, from least to } \\
\text { most regulated) }\end{array}$ & Fernández et al. (2016) \\
\hline$C R I_{\text {direct }, \text { it }}$ & $\begin{array}{l}\text { Direct investment inflow } \\
\text { restrictions }\end{array}$ & $\begin{array}{l}\text { Value lies between } 0 \text { to } 1 \text {, from least to } \\
\text { most regulated }\end{array}$ & Fernández et al. (2016) \\
\hline$C R I_{\text {equity it }}$ & Equity inflow restrictions & $\begin{array}{l}\text { Value lies between } 0 \text { to } 1 \text {, from least to } \\
\text { most regulated }\end{array}$ & Fernández et al. (2016) \\
\hline$C R N I_{\text {equity it }}$ & $\begin{array}{l}\text { Restrictions on purchasing } \\
\text { equity locally by nonresidents }\end{array}$ & $\begin{array}{l}\text { Value lies between } 0 \text { to } 1 \text {, from least to } \\
\text { most regulated }\end{array}$ & Fernández et al. (2016) \\
\hline$C R R I_{\text {equity }, \text { it }}$ & $\begin{array}{l}\text { Restrictions on equity sales or } \\
\text { issues abroad by residents }\end{array}$ & $\begin{array}{l}\text { Value lies between } 0 \text { to } 1 \text {, from least to } \\
\text { most regulated }\end{array}$ & Fernández et al. (2016) \\
\hline$C R I_{d e b t, i t}$ & $\begin{array}{l}\text { Bond and money market inflow } \\
\text { restrictions }\end{array}$ & $\begin{array}{l}\text { Value lies between } 0 \text { to } 1 \text {, from least to } \\
\text { most regulated }\end{array}$ & Fernández et al. (2016) \\
\hline$C R N I_{d e b t, i t}$ & $\begin{array}{l}\text { Restrictions on bond and } \\
\text { money market instrument } \\
\text { purchases locally by } \\
\text { nonresidents }\end{array}$ & $\begin{array}{l}\text { Value lies between } 0 \text { to } 1 \text {, from least to } \\
\text { most regulated }\end{array}$ & Fernández et al. (2016) \\
\hline$C R R I_{d e b t, i t}$ & $\begin{array}{l}\text { Restrictions on the sale or issue } \\
\text { of bond and money market } \\
\text { instruments abroad by residents }\end{array}$ & $\begin{array}{l}\text { Value lies between } 0 \text { to } 1 \text {, from least to } \\
\text { most regulated }\end{array}$ & Fernández et al. (2016) \\
\hline$C R I_{\text {other }, \text { it }}$ & $\begin{array}{l}\text { Commercial and financial credit } \\
\text { inflow restrictions }\end{array}$ & $\begin{array}{l}\text { Value lies between } 0 \text { to } 1 \text {, from least to } \\
\text { most regulated }\end{array}$ & Fernández et al. (2016) \\
\hline
\end{tabular}


Table 1 continued

\begin{tabular}{|c|c|c|c|}
\hline Variables & & Measurements & Data Source \\
\hline$C R I_{k,(j \neq i) t}$ & $\begin{array}{l}\text { Capital inflow restrictions type } k \\
\text { asset imposed by other } \\
\text { countries }\end{array}$ & $\begin{array}{l}\text { Weighted average of capital inflows } \\
\text { restrictions of other countries for type } k \\
\text { asset. Weight by GDP per capita of each } \\
\text { country. Alternative weight is the share of its } \\
\text { importance as a trade partner. Value lies } \\
\text { between } 0 \text { to 1, from least to most regulated. }\end{array}$ & $\begin{array}{l}\text { Fernández et al. (2016); } \\
\text { World Bank, World } \\
\text { Development } \\
\text { Indicators; United } \\
\text { Nations (UN) } \\
\text { Comtrade data, } \\
\text { calculated by the } \\
\text { author }\end{array}$ \\
\hline CRO & $\begin{array}{l}\text { Overall outflow restrictions } \\
\text { index }\end{array}$ & $\begin{array}{l}\text { Average of all inflow restrictions (value lies } \\
\text { between } 0 \text { to } 1 \text {, from least to most } \\
\text { regulated) }\end{array}$ & Fernández et al. (2016) \\
\hline $\mathrm{CRO}_{\text {direct, }, \text { it }}$ & $\begin{array}{l}\text { Direct investment outflow } \\
\text { restrictions }\end{array}$ & $\begin{array}{l}\text { Value lies between } 0 \text { to } 1 \text {, from least to most } \\
\text { regulated }\end{array}$ & Fernández et al. (2016) \\
\hline $\mathrm{CRO}_{\text {equity }, \text { it }}$ & Equity outflow restrictions & $\begin{array}{l}\text { Value lies between } 0 \text { to } 1 \text {, from least to most } \\
\text { regulated }\end{array}$ & Fernández et al. (2016) \\
\hline$C R N O_{\text {equity it }}$ & $\begin{array}{l}\text { Restrictions on equity sales or } \\
\text { issues by nonresidents }\end{array}$ & $\begin{array}{l}\text { Value lies between } 0 \text { to } 1 \text {, from least to most } \\
\text { regulated }\end{array}$ & Fernández et al. (2016) \\
\hline$C R R O_{\text {equity }, \text { it }}$ & $\begin{array}{l}\text { Restrictions equity purchases } \\
\text { abroad by residents }\end{array}$ & $\begin{array}{l}\text { Value lies between } 0 \text { to } 1 \text {, from least to most } \\
\text { regulated }\end{array}$ & Fernández et al. (2016) \\
\hline$C R O_{\text {debt }, i t}$ & $\begin{array}{l}\text { Bond and money market } \\
\text { outflow restrictions }\end{array}$ & $\begin{array}{l}\text { Value lies between } 0 \text { to } 1 \text {, from least to most } \\
\text { regulated }\end{array}$ & Fernández et al. (2016) \\
\hline $\mathrm{CRNO}_{\text {debt }, i t}$ & $\begin{array}{l}\text { Restrictions on the sale or issue } \\
\text { of bond and money market } \\
\text { instruments locally by } \\
\text { nonresidents }\end{array}$ & $\begin{array}{l}\text { Value lies between } 0 \text { to } 1 \text {, from least to most } \\
\text { regulated }\end{array}$ & Fernández et al. (2016) \\
\hline$C R R O_{\text {debt,it }}$ & $\begin{array}{l}\text { Restrictions on the purchase of } \\
\text { bond and money market } \\
\text { instruments abroad by residents }\end{array}$ & $\begin{array}{l}\text { Value lies between } 0 \text { to } 1 \text {, from least to most } \\
\text { regulated }\end{array}$ & Fernández et al. (2016) \\
\hline$C R O_{\text {other }, i t}$ & $\begin{array}{l}\text { Commercial and financial credit } \\
\text { outflow restriction }\end{array}$ & $\begin{array}{l}\text { Value lies between } 0 \text { to } 1 \text {, from least to most } \\
\text { regulated }\end{array}$ & Fernández et al. (2016) \\
\hline$C R O_{k,(j \neq i) t}$ & $\begin{array}{l}\text { Capital outflow on type } k \text { asset } \\
\text { imposed by other countries }\end{array}$ & $\begin{array}{l}\text { Weighted average of capital outflows } \\
\text { restrictions of other countries for type } k \\
\text { asset. Weight by GDP per capita of each } \\
\text { country. Alternative weight is the share of } \\
\text { its importance as a trade partner. Value lies } \\
\text { between } 0 \text { to } 1 \text {, from least to most regulated. }\end{array}$ & $\begin{array}{l}\text { Fernández et al. (2016); } \\
\text { World Bank, World } \\
\text { Development } \\
\text { Indicators; UN } \\
\text { Comtrade data, } \\
\text { calculated by the } \\
\text { author. }\end{array}$ \\
\hline$g d p \_p e r c a p i t a \_g_{i}$ & $\begin{array}{l}\text { Growth of real GDP per capita } \\
\text { in country }(\%)\end{array}$ & $\begin{array}{l}\text { Derived using GDP per capita (constant } \\
2010 \text { United States [US] dollars) }\end{array}$ & $\begin{array}{l}\text { World Bank, World } \\
\text { Development } \\
\text { Indicators }\end{array}$ \\
\hline$r \_i n \_d i f f \_u s^{i}$ & $\begin{array}{l}\text { Real interest rate differential } \\
\text { between country } i \text { and the US } \\
(\%)\end{array}$ & $\begin{array}{l}\text { Domestic real interest rate (lending interest } \\
\text { rate) minus the US real interest rate }\end{array}$ & $\begin{array}{l}\text { World Bank, World } \\
\text { Development } \\
\text { Indicators }\end{array}$ \\
\hline$e x_{i}$ & Nominal exchange rate & $\begin{array}{l}\text { Bilateral exchange rate (domestic currency } \\
\text { per US dollar) }\end{array}$ & $\begin{array}{l}\text { IMF International } \\
\text { Financial Statistics (IFS) }\end{array}$ \\
\hline
\end{tabular}


Table 1 continued

\begin{tabular}{|c|c|c|c|}
\hline Variables & & Measurements & Data Source \\
\hline reer $_{i}$ & Real effective exchange rate & $\begin{array}{l}\prod_{i=1}^{m}\left[E_{i} P_{i}^{w}\right]^{\omega_{i}} \\
P^{d} \\
\text { where } E \text { denotes the nominal exchange rate } \\
\text { (measured as domestic currency per foreign } \\
\text { currency), } P^{w} \text { is an index of foreign prices } \\
\text { (proxied by the consumer price index), } P^{d} \text { is } \\
\text { an index of domestic prices (proxied by the } \\
\text { consumer price index), and } m \text { is the number } \\
\text { of trading partner countries. The geometric } \\
\text { averaging method is used where } \omega_{i} \text { is the } \\
\text { appropriate weight for each ith foreign } \\
\text { country, and the sum of weights must equal } \\
\text { one or } \sum \omega_{l}=1 \text {. }\end{array}$ & $\begin{array}{l}\text { Author's calculation } \\
\text { using IMF IFS and UN } \\
\text { Comtrade data }\end{array}$ \\
\hline$d c \_g d p_{i}$ & $\begin{array}{l}\text { The ratio of domestic credit to } \\
\text { the private sector to gross } \\
\text { domestic product }\end{array}$ & $\%$ of GDP & $\begin{array}{l}\text { World Bank, World } \\
\text { Development } \\
\text { Indicators }\end{array}$ \\
\hline stocktrade_gdpi & $\begin{array}{l}\text { The ratio of stock market trade } \\
\text { to GDP }\end{array}$ & $\%$ of GDP & $\begin{array}{l}\text { World Bank, World } \\
\text { Development } \\
\text { Indicators }\end{array}$ \\
\hline trade_gdp & Trade openness & Ratio of trade to GDP (\% of GDP) & $\begin{array}{l}\text { World Bank, World } \\
\text { Development } \\
\text { Indicators }\end{array}$ \\
\hline$n r_{i}$ & $\begin{array}{l}\text { The ratio of natural resource } \\
\text { endowment of a country }\end{array}$ & $\begin{array}{l}\text { Sum of agriculture raw materials exports, } \\
\text { fuel exports, and ores and metals exports } \\
\text { (\% of merchandise exports) }\end{array}$ & $\begin{array}{l}\text { World Bank, World } \\
\text { Development } \\
\text { Indicators }\end{array}$ \\
\hline VIX & Volatility Index & $\begin{array}{l}\text { The S\&P } 500 \text { Index and estimates of } \\
\text { expected volatility by averaging the } \\
\text { weighted prices of the index's puts and } \\
\text { calls over a wide range of strike prices. }\end{array}$ & $\begin{array}{l}\text { Volatility Index } \\
\text { historical data from the } \\
\text { Chicago Board Options } \\
\text { Exchange }\end{array}$ \\
\hline$P R S_{i}$ & Good governance & $\begin{array}{l}\text { Political Risk Index (between } 0 \text { to } 1 \text {, } \\
\text { from highest to lowest) }\end{array}$ & PRS Group \\
\hline govcon_gdp $p_{i t}$ & $\begin{array}{l}\text { The ratio of government } \\
\text { consumption spending to GDP }\end{array}$ & $\%$ of GDP & $\begin{array}{l}\text { World Bank, World } \\
\text { Development } \\
\text { Indicators }\end{array}$ \\
\hline$P R O D_{i t}$ & Productivity differentials & $\begin{array}{l}\text { Ratio of a country's real GDP per capita } \\
\text { (\$ prices) to the US }\end{array}$ & $\begin{array}{l}\text { World Bank, World } \\
\text { Development } \\
\text { Indicators }\end{array}$ \\
\hline tot $_{i t}$ & Terms of trade & Ratio of export prices to import prices & $\begin{array}{l}\text { World Bank, World } \\
\text { Development } \\
\text { Indicators }\end{array}$ \\
\hline$M I_{i t}$ & Monetary policy independence & $\begin{array}{l}M I_{i t}=1-\frac{\operatorname{cor}\left(r_{i}, r_{u s}\right)+1}{2} \text { where } \operatorname{cor}\left(r_{i}, r_{u s}\right) \\
\text { measures the correlation of the monthly } \\
\text { interest rates between the home country } \\
\text { and the US. Interest rates are proxied by the } \\
\text { lending rate. The value lies between } 0 \text { and } 1 \text {, } \\
\text { from high correlation (low monetary } \\
\text { independence) to low correlation (high } \\
\text { monetary independence). This formula is in } \\
\text { Aizenman, Chinn, and Ito (2010). }\end{array}$ & IMF IFS \\
\hline
\end{tabular}


Table 1 continued

\begin{tabular}{|c|c|c|c|}
\hline Variables & & Measurements & Data Source \\
\hline RERvolatility & Exchange rate volatility & $\begin{array}{l}\text { Real exchange rate volatility measured by } \\
\text { two alternatives: standard deviation of } \\
\text { monthly real exchange rate (RERvolatility), } \\
\text { and GRACH }(1,1) \text { (RERvolatility } 1)\end{array}$ & IMF IFS \\
\hline $\mathrm{Peg}_{i}$ & Fixed exchange rate regime & $\begin{array}{l}\text { Dummy variable: } 1 \text { = de facto fixed } \\
\text { exchange rate (hard and soft peg regime), } \\
0=\text { floating (managed and freely floating) }\end{array}$ & $\begin{array}{l}\text { IMF. 2002-2016. } \\
\text { Annual Report on } \\
\text { Exchange Arrangements } \\
\text { and Exchange } \\
\text { Restrictions }\end{array}$ \\
\hline bm_reserves ${ }_{i t}$ & Degree of sterilization & $\begin{array}{l}\text { Ratio of broad money to foreign reserves; } \\
\text { change to index by } 2000=1\end{array}$ & $\begin{array}{l}\text { World Bank, World } \\
\text { Development } \\
\text { Indicators }\end{array}$ \\
\hline Inflation $_{i}$ & Inflation (\%) & Changes in consumer price index & IMFIFS \\
\hline
\end{tabular}

Source: Author.

Table 2: Summary of Variables for Generalized Method of Moments Estimators

\begin{tabular}{|c|c|c|c|c|c|}
\hline Variable & Obs & Mean & Std. Dev. & Min & Max \\
\hline$C F I / G D P$ & 170 & 15.596 & 24.624 & 0 & 139.050 \\
\hline CFO/GDP & 170 & 16.597 & 27.464 & 0 & 153.520 \\
\hline$C F I_{\text {direct }} / G D P$ & 170 & 6.834 & 10.078 & 0 & 58.510 \\
\hline$C F O_{\text {direct }} / G D P$ & 170 & 4.950 & 9.085 & 0 & 48.340 \\
\hline$C F I_{\text {equity }} / G D P$ & 155 & 1.489 & 3.258 & 0 & 27.369 \\
\hline $\mathrm{CFO}_{\text {equity }} / \mathrm{GDP}$ & 155 & 2.964 & 5.735 & 0 & 32.821 \\
\hline$C F I_{\text {debt }} / G D P$ & 140 & 1.185 & 2.045 & 0 & 15.177 \\
\hline $\mathrm{CFO}_{\text {debt }} / \mathrm{GDP}$ & 140 & 2.716 & 4.697 & 0 & 21.075 \\
\hline $\mathrm{CFI}_{\text {other }} / \mathrm{GDP}$ & 163 & 6.779 & 14.271 & 0 & 92.570 \\
\hline $\mathrm{CFO}_{\text {other }} / \mathrm{GDP}$ & 163 & 7.100 & 13.091 & 0 & 85.480 \\
\hline $\mathrm{CFI}_{\text {direct }} /$ totalinflows & 168 & 0.503 & 0.238 & 0 & 1.000 \\
\hline$C R I_{\text {direct, it }}$ & 160 & 0.644 & 0.480 & 0 & 1.000 \\
\hline$C R I_{\text {equity,it }}$ & 160 & 0.597 & 0.422 & 0 & 1.000 \\
\hline$C R I_{\text {debt }, i t}$ & 160 & 0.588 & 0.419 & 0 & 1.000 \\
\hline$C R I_{\text {other, it }}$ & 160 & 0.616 & 0.432 & 0 & 1.000 \\
\hline$C R I$ & 160 & 0.596 & 0.341 & 0 & 1.000 \\
\hline$C R O$ & 160 & 0.670 & 0.374 & 0 & 1.000 \\
\hline$C R O_{\text {direct, it }}$ & 160 & 0.613 & 0.489 & 0 & 1.000 \\
\hline$C R O_{\text {equty,it }}$ & 160 & 0.663 & 0.444 & 0 & 1.000 \\
\hline
\end{tabular}


22 | ADB Economics Working Paper Series No. 578

Table 2 continued

\begin{tabular}{|c|c|c|c|c|c|}
\hline Variable & Obs & Mean & Std. Dev. & Min & Max \\
\hline$C R O_{\text {debt,it }}$ & 160 & 0.686 & 0.426 & 0 & 1.000 \\
\hline $\mathrm{CRO}_{\text {other,it }}$ & 160 & 0.700 & 0.381 & 0 & 1.000 \\
\hline$C R I_{\text {direct, }(j \neq i) t}$ & 160 & 0.325 & 0.108 & 0.148 & 0.590 \\
\hline 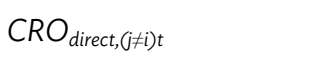 & 160 & 0.254 & 0.094 & 0.139 & 0.577 \\
\hline$C R I_{\text {equity, }(j \neq i) t}$ & 160 & 0.207 & 0.064 & 0.120 & 0.409 \\
\hline 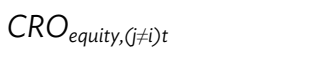 & 160 & 0.250 & 0.088 & 0.132 & 0.521 \\
\hline$C R I_{\text {debt, }(j \neq i) t}$ & 160 & 0.198 & 0.049 & 0.133 & 0.359 \\
\hline$C R O_{\text {debt, }(j \neq i) t}$ & 160 & 0.284 & 0.102 & 0.139 & 0.583 \\
\hline$C R I_{\text {other },(j \neq i) t}$ & 160 & 0.242 & 0.109 & 0.107 & 0.588 \\
\hline$C R O_{\text {other, }(j \neq i) t}$ & 160 & 0.432 & 0.096 & 0.288 & 0.739 \\
\hline stocktrade_gdp & 158 & 99.367 & 150.259 & 2.633 & 952.667 \\
\hline trade_gdp & 170 & 145.961 & 121.729 & 26.275 & 442.620 \\
\hline$n r$ & 170 & 15.400 & 10.784 & 2.586 & 49.509 \\
\hline$d c \_g d p$ & 170 & 94.312 & 47.932 & 18.698 & 233.211 \\
\hline r_in_diff_us & 170 & 0.675 & 2.595 & -9.782 & 7.100 \\
\hline VIX & 170 & 20.403 & 6.190 & 12.807 & 32.693 \\
\hline PRS & 170 & 0.640 & 0.113 & 0.420 & 0.890 \\
\hline$g d p \_p e r c a p i t a \_g_{i}$ & 170 & 4.350 & 2.902 & -4.271 & 13.636 \\
\hline$e x_{i}$ & 170 & 2906 & 5869 & 1.250 & 21935 \\
\hline reer $_{i}$ & 170 & 104.149 & 13.404 & 77.683 & 159.504 \\
\hline rer $_{i}$ & 170 & 110.644 & 18.333 & 82.629 & 186.739 \\
\hline govcon_gdp & 169 & 11.068 & 2.828 & 5.465 & 17.305 \\
\hline$P R O D$ & 170 & 0.265 & 0.315 & 0.018 & 1.116 \\
\hline tot & 170 & 0.946 & 0.176 & 0.511 & 1.366 \\
\hline bm_reserve & 170 & 0.936 & 0.369 & 0 & 2.624 \\
\hline Peg & 170 & 0.382 & 0.487 & 0 & 1.000 \\
\hline RERvolatility (SD) & 170 & 0.944 & 0.816 & 0.208 & 7.092 \\
\hline RERvolatility1 (GRACH) & 170 & 1.355 & 0.811 & 0.369 & 6.541 \\
\hline MI (lending rate) & 170 & 0.444 & 0.225 & 0.004 & 0.976 \\
\hline Inflation & 170 & 3.731 & 3.535 & -3.686 & 23.116 \\
\hline
\end{tabular}

Source: Author. 


\section{B. Econometric Procedure}

For analyzing the effects of capital account policy on the volume of capital flows, a panel system generalized method of moments (GMM) technique is applied to deal with unobservable heterogeneity, including lagged dependent variable as an explanatory variable, and the potential endogeneity of dependent and other explanatory variables in the model. ${ }^{15}$ Equation (2) is used as an example to show how a panel system GMM technique is appropriate for capital flow equation where its own lagged value is likely to influence movements of capital flows. ${ }^{16}$ Equation (2) can be rewritten when a lagged dependent variable is included in the model as follows:

$$
\left(\frac{C F I_{k}}{G D P}\right)_{i t}=c_{o, i t}+c_{1, i t}\left(\frac{C F I_{k}}{G D P}\right)_{i t-1}+c_{1, i t} C R I_{k, i t}+X_{i t} \theta+\eta_{i}+\varepsilon_{i t}
$$

The usual solution to the problem of an explanatory variable being correlated with $\eta$ is to eliminate the latter through a fixed effect transformation. Applying this approach to a dynamic model such as in equation (13) will generate an alternative source of bias, however. To illustrate, the first difference transformation of equation (13) is:

$$
\left(\frac{C F I_{k}}{G D P}\right)_{i t}-\left(\frac{C F I_{k}}{G D P}\right)_{i t-1}=c_{1, i t}^{*}\left[\left(\frac{C F I_{k}}{G D P}\right)_{i t-1}-\left(\frac{C F I_{k}}{G D P}\right)_{i t-2}\right]+\ldots \ldots \ldots \ldots . . .+\varepsilon_{i t}-\varepsilon_{i t-1} .
$$

The independent term in equation (13) is contemporaneously correlated with the error term $\left(\varepsilon_{i t}\right)$; this means the lagged values of the dependent term will also be correlated with the lagged values of the error term. In other words, in equation (14), the differenced lagged term $\left[(C F I / G D P)_{i t-1}-(C F I / G D P)_{i t-2}\right]$ is correlated with the differenced error term $\left(\varepsilon_{i t}-\varepsilon_{i, t-1}\right)$. Thus, if equation (13) is estimated by the fixed effect, the estimated coefficient will be biased.

Arellano and Bond (1991) propose an estimation technique using panel system GMM regressions. The first step is to eliminate unobservable heterogeneity $\left(\eta_{i}\right)$ by first-differencing equation (13) to become equation (14). Endogeneity problems are addressed by using the equations' own lagged levels as instruments. ${ }^{17}$ Although GMM regression under Arellano and Bond (1991) has important advantages for this exercise, it also has shortcomings. In particular, the difference estimator has been found to have poor finite sample properties when the lagged levels of the series are only weakly correlated with subsequent first differences. This was the case when the explanatory variables have large autoregressive parameters, as in this case. Blundell and Bond (1998) clearly showed that weak instruments could cause large finite sample biases when using the first-differenced GMM method.

15 For capital inflows and outflows, and the composition of capital inflow equations, the key endogenous variables include exchange rate, GDP per capita growth, and all capital restrictions. For the exchange rate equation, endogenous variables include all types of capital inflows and capital controls. GDP per capita, exchange rate, sterilization, and capital account policy are treated as endogenous variables in monetary independence equations.

16 A panel system GMM is also applied for capital outflows, composition of capital inflows, real exchange rate, and monetary independence equations.

17 Under a dynamic panel model, both first and second lagged levels of the variables as instruments are applied. However, the second lagged level of the variables is insignificant, so that only the first lagged level is applied here. In addition, both the Sargan-Hansen test of overidentifying restrictions and serial correlation is better when only the first lagged level is included. 
To redress the potential biases of having weak instruments associated with the difference GMM estimator under Arellano and Bond (1991), Blundell and Bond (1998) included more informative moment conditions in the estimation, and proposed a system estimation in which the first difference is estimated together with one in level, instead of estimating only equations in first differences and using lagged levels as instruments. The instruments for the regression in difference are its own lagged levels, as proposed by Arellano and Bond (1991), while the instruments for the regression in level are its own lagged first differences of the variable. The appropriateness of the latter is based on the assumption that the first differences are uncorrelated with the error term and unobservable heterogeneity.

The consistency of the GMM estimator depends on the validity of the instruments. Two specifications are tested. The first is the Sargan-Hansen test of overidentifying restrictions. When an equation is overidentified (that is, there are more instruments than endogenous regressors), it is possible to test whether the excluded instruments are independent of the error process. A strong rejection of the null hypothesis of the Sargan-Hansen test (that is, all instruments are uncorrelated with the error terms) casts doubt on the validity of an estimation. The second specification is to test for second serial correlation, or $\operatorname{AR}(2)$. The Arellano-Bond test for $\operatorname{AR}(2)$ is performed to check whether there is an absence of second-order serial correlation in disturbance-the null hypothesis. $A$ rejection of the null hypothesis could result from insufficient lags (AR residuals) or from instruments that have not been sufficiently lagged. The GMM estimator is consistent when there is no secondorder serial correlation in the first-differenced residuals. Note that first-order serial correlation in disturbance are not tested because a correlation is always expected due to the lagged dependent variables and, thus, this should not constitute a problem.

\section{RESULTS}

\section{A. Effectiveness of Capital Account Policy on Volume of Capital Flows}

Tables 3A, 4A, 5A, and 6A present the results quantifying the effectiveness of capital account policy on capital inflows for all four types of capital flows: direct investment, equity, debt securities, and other investment. In each of these four tables, column A shows the results when capital inflow and outflow restrictions corresponding to each type of capital flows are included in equation (2), column B shows the results when the asymmetric effects of effective capital controls are examined (equation 3 ), and column $C$ shows the findings when capital restrictions on nonresidents and residents are analyzed for capital inflows and outflows (equation 4$).{ }^{18}$ Outcomes are shown in columns $D, E$, and $F$ when the following are analyzed: (i) substitution between capital inflow and outflow controls (equation 5), (ii) substitutions in capital account policies on each type of capital flow (equation 6), and (iii) the impacts of capital account policy imposed by other countries (equation 7).

The results show that not all capital account policies are effective in affecting their own capital flows. In the case of capital inflows, only the restrictions on direct investment and equity inflows are effective. This is reflected by the negative and statistical significance of coefficients associated with the direct investment and equity inflow restrictions of Tables $3 \mathrm{~A}$ and $4 \mathrm{~A}$, columns $\mathrm{A}$. In these two cases, the expectation is that the stronger the restrictions, the lower the capital inflows. The effectiveness of direct investment and equity inflow restrictions could be because these restrictions are easier to monitor and help deter foreign equity participation. For other types of capital inflows, judgments or approval by the authorities tend to be involved. Note that when inflow restrictions on other asset types

18 Note that nonresidents and residents are analyzed here only for equity and debt securities. 
are included, debt security inflow restrictions become effective in reducing debt security inflows (Table 5A, column E).

When the possibility of asymmetric effects in which the effect of tightening capital controls may be different from loosening controls is tested, asymmetric effects are detected only in equity inflow restrictions, not in direct investment inflow restrictions (Tables $3 \mathrm{~A}$ and $4 \mathrm{~A}$, columns $\mathrm{B}$ ). From the negative and statistical significance of the coefficient associated with $C R l_{\text {equity }} \cdot D^{\text {loosen }}$, it can be inferred that any loosening of equity inflow restrictions, reflected by a lower capital restriction index, has a stronger effect (high equity inflows) than the tightening of such restrictions (high capital restriction index) in absolute terms.

The effectiveness of equity inflow restrictions is more apparent for nonresidents. Table 4A, column $\mathrm{C}$, shows that the coefficient associated with restrictions on buying equity locally by nonresidents $\left(C R N I_{\text {equity }}\right)$ is negative and statistically significant, while the coefficient associated with restrictions on sales (or equities issued abroad) by residents in equity ( $C R R I_{\text {equity }}$ ) is negative but statistically insignificant. The insignificance of restrictions on residents could be because these restrictions are looser in most emerging Asian countries than they are for nonresidents. In the PRC, for example, shares issued abroad by local firms have to be approved by the China Securities Regulatory Commission. Funds originating from these share issues are not subject to repatriation requirements and may be converted to renminbi and used in the PRC. Equity inflow restrictions are tighter for nonresidents and limits are imposed on investors. In the PRC, QFIls can invest domestically in A shares, subject to certain conditions - for example, the overall investment limit for QFIls is $\$ 150$ billion; the upper limit for a single QFII is $\$ 1$ billion; and the upper limit for sovereign funds, central banks, and monetary authorities can exceed $\$ 1$ billion.

The results show that capital outflow restrictions do not have a significant influence on capital inflows. Coefficients associated with $C R O_{k, i t}$ are statistically insignificant in all types of capital inflows, as shown in Tables 3A, 4A, 5A, and 6A, columns $C$. The insignificance of these variables could be because, after the Asian financial crisis, most emerging countries in the region did not impose any significant policy changes on capital outflow controls. So, investors who brought in capital were not constrained by any significant capital outflow restrictions.

For the presence of a substitution effect among capital controls, the results in Tables 3A, 4A, $5 A$, and $6 A$, columns $D$, suggest that direct investment inflows and equity inflows are complementary-and this is reflected by the negative coefficient associated with $C R I_{\text {equity }}$ in the direct investment inflows equation and that associated with $C R I_{\text {direct }}$ in the equity inflows equation. Restrictions on equity inflows could reduce direct investment inflows and vice versa. The results also show that restrictions on direct investment inflows could reduce debt security inflows, reflecting complementarity between these two capital inflows (Table 5A, column D). For equity inflows, both direct investment inflow restrictions and restrictions on debt security inflows are effective. Complementarity among these capital inflows may to some extent reflect that capital controls on one of these asset types sends a bad signal to the market and reduces other types of capital inflows. The complementarity of these three types of assets is also found in Gochoco-Bautista, Jongwanich, and Lee (2012). For other capital inflows, no significant effects are observed from restrictions imposed on other asset types. 
An interesting finding is that when the effects of capital inflow restrictions imposed by other countries are considered, it was only for direct investments where restrictions in neighboring countries deflected direct investment to other countries. Column $\mathrm{F}$ in Table 3A shows that the coefficient associated with $C R I_{\text {direct, }(j \neq i) t}$ is positive and statistically significant. The substitution of direct investment inflows in emerging Asia could, to some extent, reflect both shared comparable production bases and competition to attract FDI. Giordani et al. (2017) presented strong evidence that capital restrictions deflect capital flows to other countries with similar economic characteristics. For other types of assets, however, restrictions in neighboring countries reduce capital inflows into an emerging Asia country. This is reflected by the negative and significant coefficient associated with $C R I_{\text {equity, }(j \neq i) t}, C R I_{\text {debt, }(j \neq i) t}, C R I_{\text {other, }(j \neq i) t}$ shown in Tables $4 \mathrm{~A}, 5 \mathrm{~A}$, and $6 \mathrm{~A}$, columns $\mathrm{F}$. The complementarity among these flows in emerging Asian countries implies that changes in market sentiment in one country could affect other countries in the region.

Table 3: Effectiveness of Capital Controls on Direct Investment Flows

\begin{tabular}{|c|c|c|c|c|c|}
\hline & \multicolumn{5}{|c|}{ A. Inflow } \\
\hline & $\begin{array}{l}\text { Its Own } \\
\text { Restriction }\end{array}$ & Asymmetric & Inflow/Outflow & Among Assets & $\begin{array}{l}\text { Among } \\
\text { Countries }\end{array}$ \\
\hline$L_{1 . C F I_{\text {direct }} / G D P}$ & $\begin{array}{l}0.435^{* * *} \\
(0.099)\end{array}$ & $\begin{array}{c}0.437^{* * *} \\
(0.100)\end{array}$ & $\begin{array}{l}0.434^{* * *} \\
(0.995)\end{array}$ & $\begin{array}{l}0.392^{* * *} \\
(0.095)\end{array}$ & $\begin{array}{l}0.414^{* * *} \\
(0.106)\end{array}$ \\
\hline$g d p_{-}$percapita_g & $\begin{array}{l}0.379^{* *} \\
(0.152)\end{array}$ & $\begin{array}{c}0.379^{* * *} \\
(0.143)\end{array}$ & $\begin{array}{r}0.389^{* * *} \\
(0.148)\end{array}$ & $\begin{array}{l}0.372^{* *} \\
(0.156)\end{array}$ & $\begin{array}{l}0.364^{* *} \\
(0.157)\end{array}$ \\
\hline $\ln R E R$ & $\begin{array}{r}2.322 \\
(3.688)\end{array}$ & $\begin{array}{r}1.626 \\
(3.417)\end{array}$ & $\begin{array}{r}1.937 \\
(3.564)\end{array}$ & $\begin{array}{r}2.378 \\
(3.856)\end{array}$ & $\begin{array}{r}2.377 \\
(3.879)\end{array}$ \\
\hline$C R I_{\text {direct }}$ & $\begin{array}{l}-1.089^{*} \\
(0.614)\end{array}$ & $\begin{array}{r}-1.238 \\
(0.939)\end{array}$ & $\begin{array}{r}-1.389 \\
(0.953)\end{array}$ & $\begin{array}{l}-1.197^{* *} \\
(0.481)\end{array}$ & $\begin{array}{r}0.844 \\
(1.196)\end{array}$ \\
\hline Instocktrade_gdp & $\begin{array}{r}1.506^{*} \\
(0.830)\end{array}$ & $\begin{array}{r}1.671^{*} \\
(0.876)\end{array}$ & $\begin{array}{l}1.602^{* *} \\
(0.811)\end{array}$ & $\begin{array}{c}1.716^{* *} \\
(0.833)\end{array}$ & $\begin{array}{r}1.457^{*} \\
(0.770)\end{array}$ \\
\hline Intrade_gdp & $\begin{array}{r}10.588^{* * *} \\
(3.153)\end{array}$ & $\begin{array}{r}10.770^{* * *} \\
(2.947)\end{array}$ & $\begin{array}{r}10.702^{* * *} \\
(3.075)\end{array}$ & $\begin{array}{r}10.041^{* * *} \\
(3.342)\end{array}$ & $\begin{array}{r}9.653^{* * *} \\
(3.247)\end{array}$ \\
\hline $\ln n r$ & $\begin{array}{r}6.241^{* * *} \\
(1.699)\end{array}$ & $\begin{array}{r}6.427^{* * *} \\
(1.690)\end{array}$ & $\begin{array}{r}6.403^{* * *} \\
(1.663)\end{array}$ & $\begin{array}{r}6.877^{* * *} \\
(1.978)\end{array}$ & $\begin{array}{r}6.227^{* * *} \\
(1.699)\end{array}$ \\
\hline $\ln d c_{-} g d p$ & $\begin{array}{l}-2.556 \\
(2.995)\end{array}$ & $\begin{array}{l}-2.294 \\
(3.047)\end{array}$ & $\begin{array}{l}-2.197 \\
(2.661)\end{array}$ & $\begin{array}{l}-4.868 \\
(2.968)\end{array}$ & $\begin{array}{r}-1.489 \\
(3.238)\end{array}$ \\
\hline $\ln r \_i n \_d i f f \_u s$ & $\begin{array}{r}11.171 \\
(16.525)\end{array}$ & $\begin{array}{l}11.976 \\
(0.72)\end{array}$ & $\begin{array}{r}11.095 \\
(17.615)\end{array}$ & $\begin{array}{r}2.186 \\
(16.238)\end{array}$ & $\begin{array}{r}11.137 \\
(15.542)\end{array}$ \\
\hline $\ln V I X$ & $\begin{array}{l}-1.878 \\
(1.281)\end{array}$ & $\begin{array}{r}-2.069 \\
(-1.375)\end{array}$ & $\begin{array}{l}-1.972 \\
(1.335)\end{array}$ & $\begin{array}{r}1.068 \\
(1.329)\end{array}$ & $\begin{array}{l}-0.854 \\
(1.462)\end{array}$ \\
\hline PRS & $\begin{array}{l}14.883^{*} \\
(7.950)\end{array}$ & $\begin{array}{r}13.256 \\
(9.062)\end{array}$ & $\begin{array}{l}13.344^{*} \\
(7.481)\end{array}$ & $\begin{array}{r}8.865 \\
(7.912)\end{array}$ & $\begin{array}{l}13.351^{*} \\
(7.879)\end{array}$ \\
\hline$C R I_{\text {equity }}$ & $(-)$ & $(-)$ & $(-)$ & $\begin{array}{r}-3.695^{* *} \\
(1.752)\end{array}$ & $(-)$ \\
\hline
\end{tabular}


Table 3 continued

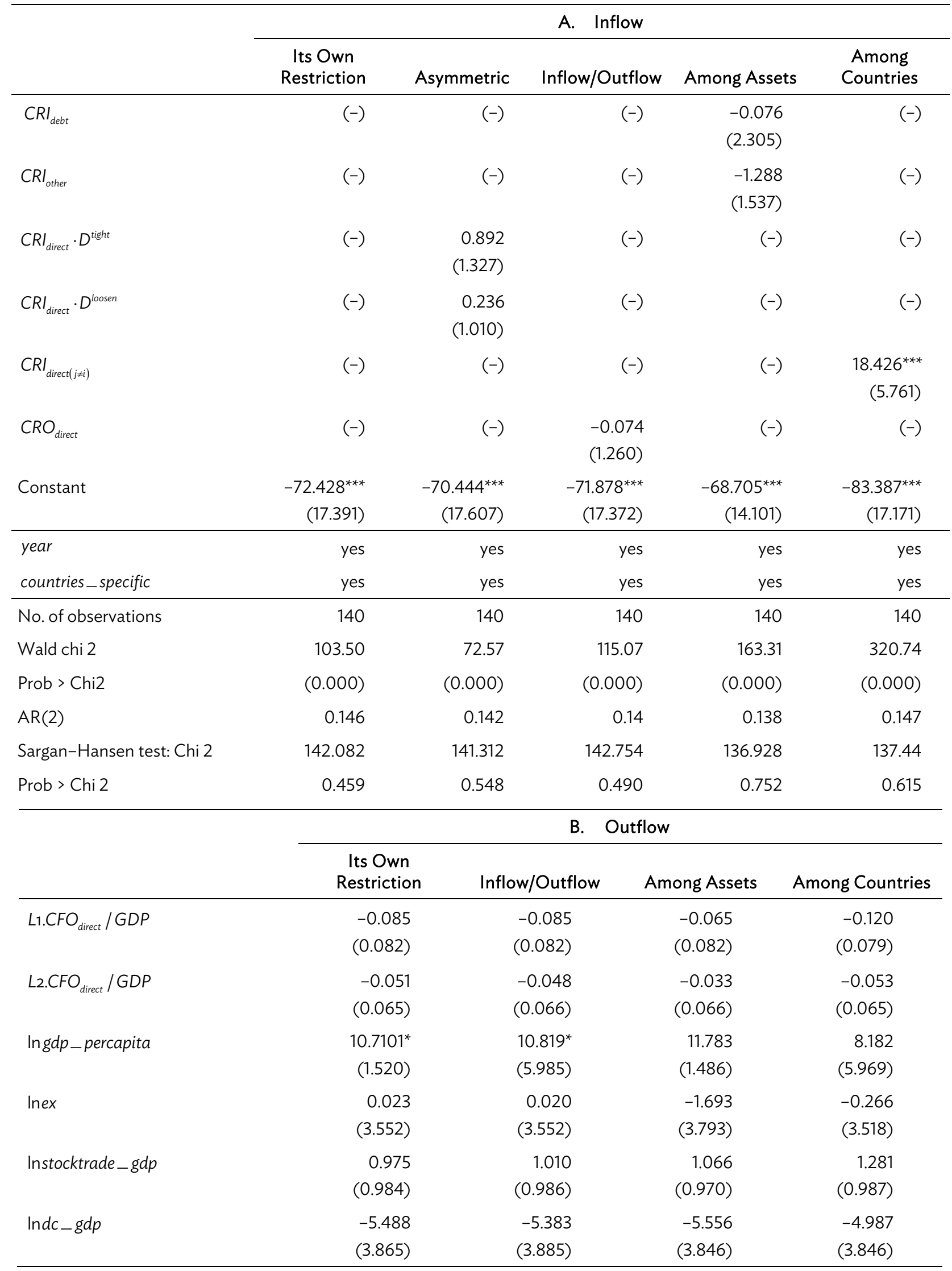


Table 3 continued

\begin{tabular}{|c|c|c|c|c|}
\hline & \multicolumn{4}{|c|}{ B. Outflow } \\
\hline & $\begin{array}{l}\text { Its Own } \\
\text { Restriction }\end{array}$ & Inflow/Outflow & Among Assets & Among Countries \\
\hline Intrade_gdp & $\begin{array}{c}9.629^{* * *} \\
(3.314)\end{array}$ & $\begin{array}{l}9.194^{* * *} \\
(3.332)\end{array}$ & $\begin{array}{r}10.041^{* * *} \\
(3.323)\end{array}$ & $\begin{array}{r}10.707^{* * *} \\
(3.297)\end{array}$ \\
\hline $\ln n r$ & $\begin{array}{r}10.870^{* * *} \\
(2.216)\end{array}$ & $\begin{array}{r}10.957^{* * *} \\
(2.221)\end{array}$ & $\begin{array}{r}10.759^{* * *} \\
(2.227)\end{array}$ & $\begin{array}{r}10.925^{* * *} \\
(2.234)\end{array}$ \\
\hline $\ln r \_i n \_d i f f \_u s$ & $\begin{array}{r}25.553 \\
(18.921)\end{array}$ & $\begin{array}{r}24.472 \\
(19.089)\end{array}$ & $\begin{array}{r}23.275 \\
(19.068)\end{array}$ & $\begin{array}{r}21.245 \\
(18.633)\end{array}$ \\
\hline $\ln V I X$ & $\begin{array}{c}-3.637^{* *} \\
(1.644)\end{array}$ & $\begin{array}{l}-3.841 \\
(1.654)\end{array}$ & $\begin{array}{r}-4.345^{* *} \\
(1.734)\end{array}$ & $\begin{array}{r}-3.293^{* *} \\
(1.605)\end{array}$ \\
\hline PRS & $\begin{array}{r}12.485 \\
(13.103)\end{array}$ & $\begin{array}{r}13.416 \\
(13.227)\end{array}$ & $\begin{array}{r}9.509 \\
(13.439)\end{array}$ & $\begin{array}{r}14.026 \\
(12.906)\end{array}$ \\
\hline$C R I_{\text {direct }}$ & $(-)$ & $\begin{array}{l}-0.932 \\
(1.428)\end{array}$ & $(-)$ & $(-)$ \\
\hline$C R O_{\text {direct }}$ & $\begin{array}{l}(5.979) \\
-8.966\end{array}$ & $\begin{array}{l}-1.126 \\
(1.531)\end{array}$ & $\begin{array}{l}-1.042 \\
(1.486)\end{array}$ & $\begin{array}{r}0.798 \\
(2.417)\end{array}$ \\
\hline$C R O_{\text {equity }}$ & $(-)$ & $(-)$ & $\begin{array}{r}-0.114 \\
(2.263)\end{array}$ & $(-)$ \\
\hline $\mathrm{CRO}_{\text {debt }}$ & $(-)$ & $(-)$ & $\begin{array}{l}-4.677 \\
(3.196)\end{array}$ & $(-)$ \\
\hline $\mathrm{CRO}_{\text {other }}$ & $(-)$ & $(-)$ & $\begin{array}{r}1.397 \\
(1.872)\end{array}$ & $(-)$ \\
\hline$C R O_{\text {direct }(j \neq i)}$ & $(-)$ & $(-)$ & $(-)$ & $\begin{array}{r}12.221 \\
(14.974)\end{array}$ \\
\hline Constant & $\begin{array}{r}-144.383^{* * *} \\
(51.815)\end{array}$ & $\begin{array}{r}-143.157^{* * *} \\
(51.984)\end{array}$ & $\begin{array}{r}-133.805^{* * *} \\
(52.933)\end{array}$ & $\begin{array}{r}-132.822^{* * *} \\
(50.881)\end{array}$ \\
\hline $\begin{array}{l}\text { year } \\
\text { countries_specific }\end{array}$ & $\begin{array}{l}\text { yes } \\
\text { yes }\end{array}$ & $\begin{array}{l}\text { yes } \\
\text { yes }\end{array}$ & $\begin{array}{l}\text { yes } \\
\text { yes }\end{array}$ & $\begin{array}{l}\text { yes } \\
\text { yes }\end{array}$ \\
\hline No. of observations & 132 & 132 & 132 & 132 \\
\hline Wald chi 2 & 649.80 & 647.85 & 654.54 & 800.90 \\
\hline Prob > Chi2 & $(0.000)$ & $(0.000)$ & $(0.000)$ & $(0.000)$ \\
\hline $\mathrm{AR}(2)$ & 0.482 & 0.461 & 0.359 & 0.406 \\
\hline Sargan-Hansen test: Chi 2 & 119.351 & 117.898 & 116.840 & 133.167 \\
\hline Prob $>$ Chi 2 & 0.8129 & 0.852 & $(0.958)$ & $(0.576)$ \\
\hline
\end{tabular}

Notes: Values in parentheses are robust standard errors. ${ }^{* *}=$ significance at $1 \%$ level, ${ }^{* *}=5 \%$, and ${ }^{*}=10 \%$. (-) refers to no presence of this variable in an estimation.

Source: Author's estimates. 
Table 4: Effectiveness of Capital Controls on Equity Flows

\begin{tabular}{|c|c|c|c|c|c|c|}
\hline & \multicolumn{6}{|c|}{ A. Inflow } \\
\hline & $\begin{array}{l}\text { Its Own } \\
\text { Restriction }\end{array}$ & Asymmetric & $\begin{array}{l}\text { Nonresident/ } \\
\text { Resident }\end{array}$ & $\begin{array}{l}\text { Inflow/ } \\
\text { Outflow }\end{array}$ & $\begin{array}{l}\text { Among } \\
\text { Assets }\end{array}$ & $\begin{array}{l}\text { Among } \\
\text { Countries }\end{array}$ \\
\hline$L_{1} . C F I_{\text {equity }} / G D P$ & $\begin{array}{r}-0.331 \\
(0.053)\end{array}$ & $\begin{array}{l}-0.028 \\
(0.052)\end{array}$ & $\begin{array}{l}-0.031 \\
(0.053)\end{array}$ & $\begin{array}{r}0.002 \\
(0.050)\end{array}$ & $\begin{array}{l}-0.430 \\
(0.048)\end{array}$ & $\begin{array}{l}-0.049 \\
(0.054)\end{array}$ \\
\hline$g d p_{-}$percapita_g & $\begin{array}{l}-0.1207 \\
(0.086)\end{array}$ & $\begin{array}{r}-0.125 \\
(0.082)\end{array}$ & $\begin{array}{r}-0.122 \\
(0.086)\end{array}$ & $\begin{array}{c}-0.093 \\
(0.082)\end{array}$ & $\begin{array}{l}-0.092 \\
(0.076)\end{array}$ & $\begin{array}{r}-0.125 \\
(0.086)\end{array}$ \\
\hline L1.gdp_percapita_g & $\begin{array}{r}0.175^{*} \\
(0.096)\end{array}$ & $\begin{array}{c}0.165^{* *} \\
(0.093)\end{array}$ & $\begin{array}{r}0.173^{*} \\
(0.096)\end{array}$ & $\begin{array}{r}0.185 \\
(0.146)\end{array}$ & $\begin{array}{r}0.149 \\
(0.096)\end{array}$ & $\begin{array}{l}0.214^{* *} \\
(0.104)\end{array}$ \\
\hline Inex & $\begin{array}{r}9.072^{* * *} \\
(3.377)\end{array}$ & $\begin{array}{r}9.205^{* * *} \\
(3.438)\end{array}$ & $\begin{array}{l}9.149^{* * *} \\
(3.396)\end{array}$ & $\begin{array}{l}7.427^{* *} \\
(3.872)\end{array}$ & $\begin{array}{r}9.879^{* * *} \\
(3.554)\end{array}$ & $\begin{array}{l}8.414^{* * *} \\
(3.185)\end{array}$ \\
\hline$C R I_{\text {equity }}$ & $\begin{array}{r}-2.851^{* *} \\
(1.147)\end{array}$ & $\begin{array}{r}-3.708^{* *} \\
(1.892)\end{array}$ & $(-)$ & $\begin{array}{r}-1.717 \\
(1.246)\end{array}$ & $\begin{array}{r}-2.963^{* *} \\
(1.305)\end{array}$ & $\begin{array}{c}-4.728^{* * *} \\
(1.907)\end{array}$ \\
\hline Instocktrade_gdp & $\begin{array}{l}1.583^{* *} \\
(0.708)\end{array}$ & $\begin{array}{c}1.537^{* *} \\
(0.684)\end{array}$ & $\begin{array}{c}1.561^{1 *} \\
(0.707)\end{array}$ & $\begin{array}{l}1.449^{* *} \\
(0.728)\end{array}$ & $\begin{array}{l}1.609^{* *} \\
(0.689)\end{array}$ & $\begin{array}{c}1.509^{* *} \\
(0.689)\end{array}$ \\
\hline Intrade_gdp & $\begin{array}{r}2.239 \\
(1.788)\end{array}$ & $\begin{array}{r}2.318 \\
(1.746)\end{array}$ & $\begin{array}{r}2.284 \\
1.759\end{array}$ & $\begin{array}{r}2.685 \\
(2.179)\end{array}$ & $\begin{array}{r}2.211 \\
(1.656)\end{array}$ & $\begin{array}{r}1.722 \\
(1.739)\end{array}$ \\
\hline $\ln n r$ & $\begin{array}{c}0.963^{*} \\
(0.548)\end{array}$ & $\begin{array}{c}1.009^{*} \\
(0.580)\end{array}$ & $\begin{array}{c}0.975^{*} \\
(0.549)\end{array}$ & $\begin{array}{c}0.706^{*} \\
(0.397)\end{array}$ & $\begin{array}{r}1.076^{*} \\
(0.629)\end{array}$ & $\begin{array}{l}1.286^{* *} \\
(0.604)\end{array}$ \\
\hline $\ln d c_{-} g d p$ & $\begin{array}{l}-8.021^{* *} \\
(3.509)\end{array}$ & $\begin{array}{l}-8.561^{* *} \\
(3.742)\end{array}$ & $\begin{array}{r}-8.186 \\
(3.498)^{* *}\end{array}$ & $\begin{array}{r}-8.236^{* *} \\
(3.883)\end{array}$ & $\begin{array}{r}-7.744^{* *} \\
(3.619)\end{array}$ & $\begin{array}{l}-7.781^{* *} \\
(3.478)\end{array}$ \\
\hline $\ln r \_i n \_d i f f \_u s$ & $\begin{array}{r}18.023 \\
(12.097)\end{array}$ & $\begin{array}{r}20.092 \\
(12.844)\end{array}$ & $\begin{array}{r}18.618 \\
(12.177)\end{array}$ & $\begin{array}{r}10.283 \\
(13.507)\end{array}$ & $\begin{array}{r}18.39^{*} \\
(11.828)\end{array}$ & $\begin{array}{r}15.348 \\
(11.667)\end{array}$ \\
\hline $\ln V I X$ & $\begin{array}{l}-0.548 \\
(0.848)\end{array}$ & $\begin{array}{l}-0.529 \\
(0.882)\end{array}$ & $\begin{array}{l}-0.528 \\
(0.864\end{array}$ & $\begin{array}{l}-0.557 \\
(0.837)\end{array}$ & $\begin{array}{r}-0.611 \\
(0.705)\end{array}$ & $\begin{array}{l}-0.588 \\
(0.827)\end{array}$ \\
\hline PRS & $\begin{array}{l}-5.345^{*} \\
(3.257)\end{array}$ & $\begin{array}{l}-4.434 \\
(3.733)\end{array}$ & $\begin{array}{l}-5.084 \\
(3.323)\end{array}$ & $\begin{array}{l}-4.864 \\
(4.626)\end{array}$ & $\begin{array}{l}-8.822 \\
(4.289)\end{array}$ & $\begin{array}{r}-5.912 \\
(2.689)\end{array}$ \\
\hline$C R I_{\text {direct }}$ & $(-)$ & $(-)$ & $(-)$ & $(-)$ & $\begin{array}{r}-1.739^{* * *} \\
(0.686)\end{array}$ & $(-)$ \\
\hline$C R I_{\text {debt }}$ & $(-)$ & $(-)$ & $(-)$ & $(-)$ & $\begin{array}{l}-1.414^{*} \\
(1.823)\end{array}$ & $(-)$ \\
\hline$C R I_{\text {other }}$ & $(-)$ & $(-)$ & $(-)$ & $(-)$ & $\begin{array}{r}-1.219 \\
(1.262)\end{array}$ & $(-)$ \\
\hline$C R I_{\text {equity }} \cdot D^{\text {tight }}$ & $(-)$ & $\begin{array}{l}-0.033 \\
(0.680)\end{array}$ & $(-)$ & $(-)$ & $(-)$ & $(-)$ \\
\hline$C R I_{\text {equity }} \cdot D^{\text {loosen }}$ & $(-)$ & $\begin{array}{l}-2.525^{*} \\
(1.340)\end{array}$ & $(-)$ & $(-)$ & $(-)$ & $(-)$ \\
\hline$C R I_{\text {equity }(j \neq i)}$ & $(-)$ & $(-)$ & $(-)$ & $(-)$ & $(-)$ & $\begin{array}{r}-18.007^{* *} \\
(8.877)\end{array}$ \\
\hline$C R O_{\text {equity }}$ & $(-)$ & $(-)$ & $(-)$ & $\begin{array}{l}2.028 \\
(2.115)\end{array}$ & $(-)$ & $(-)$ \\
\hline
\end{tabular}


Table 4 continued

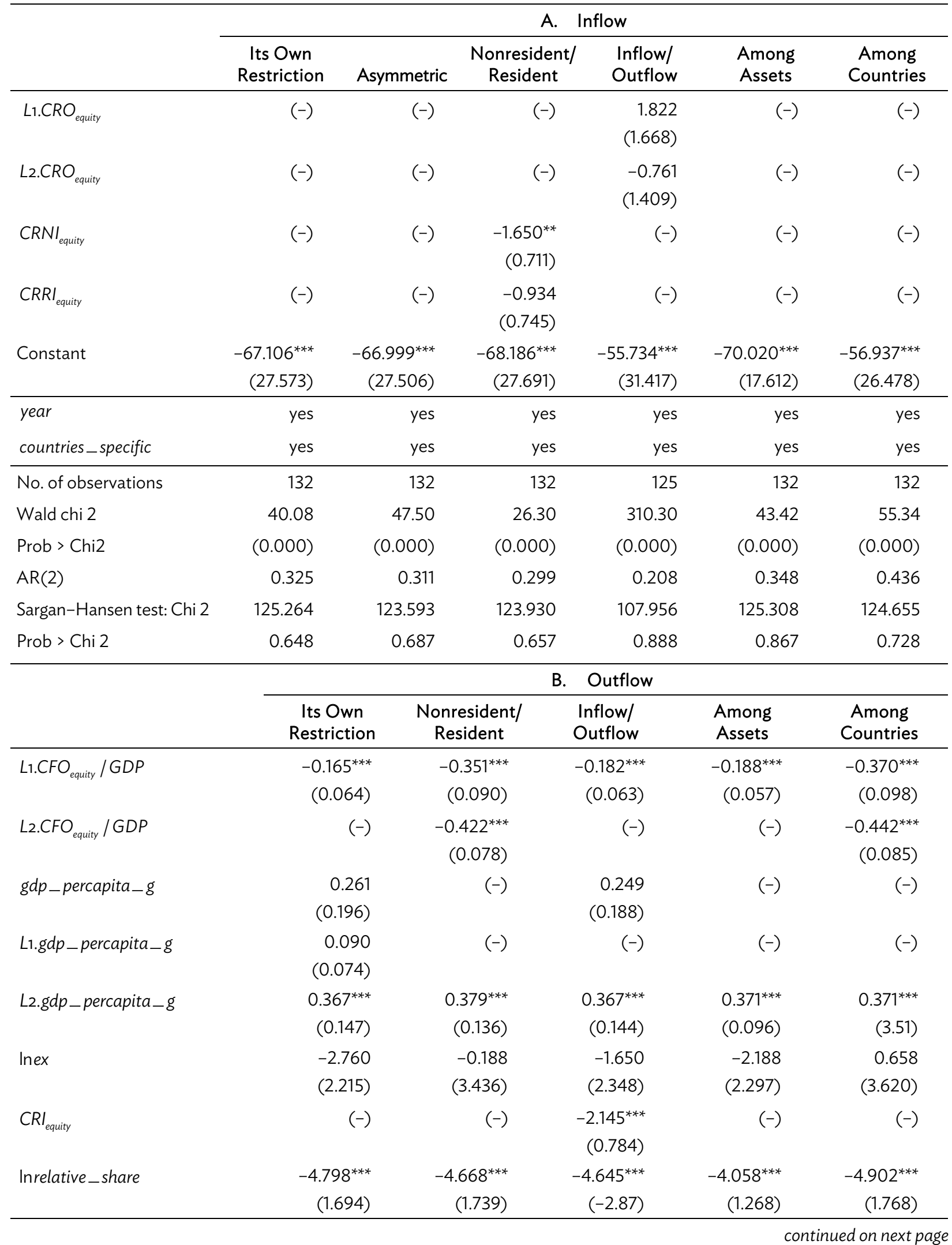


Table 4 continued

\begin{tabular}{|c|c|c|c|c|c|}
\hline & \multicolumn{5}{|c|}{ B. Outflow } \\
\hline & $\begin{array}{l}\text { Its Own } \\
\text { Restriction }\end{array}$ & $\begin{array}{c}\text { Nonresident/ } \\
\text { Resident }\end{array}$ & $\begin{array}{l}\text { Inflow/ } \\
\text { Outflow }\end{array}$ & $\begin{array}{l}\text { Among } \\
\text { Assets }\end{array}$ & $\begin{array}{l}\text { Among } \\
\text { Countries }\end{array}$ \\
\hline \multirow[t]{2}{*}{ Intrade_gdp } & -2.204 & -1.858 & -2.972 & -2.422 & -1.594 \\
\hline & $(2.054)$ & $(2.212)$ & $(2.116)$ & $(2.053)$ & $(2.315)$ \\
\hline \multirow[t]{2}{*}{$\ln n r$} & $2.261^{* *}$ & $2.426^{* *}$ & $2.553^{* *}$ & $1.763^{* * *}$ & $2.509^{* *}$ \\
\hline & $(1.103)$ & $(1.111)$ & $(1.111)$ & $(0.702)$ & (1.119) \\
\hline \multirow[t]{2}{*}{ L1. In $d c_{-} g d p$} & 3.073 & 2.525 & 2.192 & 2.083 & 1.031 \\
\hline & $(2.307)$ & $(3.486)$ & $(2.121)$ & $(1.562)$ & (4.116) \\
\hline \multirow[t]{2}{*}{ Inr_in_diff_us } & 3.343 & 7.715 & 5.207 & -7.552 & 0.417 \\
\hline & $(12.309)$ & (13.781) & $(13.384)$ & (11.093) & (11.843) \\
\hline \multirow[t]{2}{*}{ L1. $\ln V I X$} & $-3.514^{*}$ & -3.171 & $-3.739^{*}$ & $-2.481^{*}$ & 2.285 \\
\hline & $(2.052)$ & $(2.123)$ & $(2.139)$ & $(1.445)$ & (3.704) \\
\hline \multirow[t]{2}{*}{ PRS } & 7.375 & 3.527 & 6.127 & $13.050^{* *}$ & 6.639 \\
\hline & $(6.981)$ & $(8.030)$ & $(6.373)$ & $(6.782)$ & (8.104) \\
\hline \multirow[t]{2}{*}{$C R O_{\text {debt }}$} & $(-)$ & $(-)$ & $(-)$ & -0.136 & $(-)$ \\
\hline & & & & $(1.502)$ & \\
\hline \multirow{2}{*}{$C R O_{\text {other }}$} & $(-)$ & $(-)$ & $(-)$ & -6.386 & $(-)$ \\
\hline & & & & $(0.721)$ & \\
\hline \multirow{2}{*}{$C R O_{\text {equity(jii) }}$} & $(-)$ & $(-)$ & $(-)$ & $(-)$ & $30.799^{*}$ \\
\hline & & & & & $(1.091)$ \\
\hline \multirow[t]{2}{*}{$C R O_{\text {direct }}$} & $(-)$ & $(-)$ & $(-)$ & $-2.322^{* * *}$ & \\
\hline & & & & $(0.888)$ & \\
\hline \multirow{2}{*}{$C R O_{\text {equity }}$} & 1.747 & $(-)$ & 1.193 & 2.016 & $5.951^{*}$ \\
\hline & $(1.431)$ & & $(1.444)$ & (1.309) & $(3.456)$ \\
\hline \multirow[t]{2}{*}{$C R N O_{\text {equity }}$} & $(-)$ & -0.755 & $(-)$ & $(-)$ & $(-)$ \\
\hline & & $(1.226)$ & & & \\
\hline \multirow[t]{2}{*}{$C R R O_{\text {equity }}$} & $(-)$ & 1.409 & $(-)$ & $(-)$ & $(-)$ \\
\hline & & $(0.922)$ & & & \\
\hline \multirow[t]{2}{*}{ Constant } & 16.884 & -1.232 & 15.078 & 14.676 & -37.903 \\
\hline & $(15.580)$ & (21.547) & $(14.625)$ & $(17.583)$ & (39.367) \\
\hline year & yes & yes & yes & yes & yes \\
\hline countries_specific & yes & yes & yes & yes & yes \\
\hline No. of observations & 129 & 127 & 129 & 129 & 127 \\
\hline Wald chi 2 & 141.76 & 535.72 & 59.49 & 167.52 & 1195.37 \\
\hline Prob $>$ Chi2 & $(0.000)$ & $(0.000)$ & $(0.000)$ & $(0.000)$ & $(0.000)$ \\
\hline $\operatorname{AR}(2)$ & 0.132 & 0.522 & 0.143 & 0.166 & 0.543 \\
\hline Sargan-Hansen test: Chi 2 & 117.097 & 127.719 & 116.540 & 120.556 & 129.936 \\
\hline Prob $>$ Chi 2 & 0.480 & 0.197 & 0.572 & 0.667 & 0.273 \\
\hline
\end{tabular}

Notes: Value in parentheses are robust standard errors. ${ }^{* *}=$ significance at $1 \%$ level, ${ }^{* *}=5 \%$, and ${ }^{*}=10 \%$. $(-)$ refers to no presence of this variable in an estimation.

Source: Author's estimates. 
For the other control variables in this analysis of capital inflows, real GDP per capita growth ( $g d p \_$percapita_ $g_{i}$ ), the ratio of stock market trade to GDP (stocktrade_gdpi), and the ratio of a country's natural resource endowment $\left(n r_{i}\right)$ are statistically significant across all types of inflows, except debt security (Tables 3A, 4A, 5A, and 6A, columns A). ${ }^{19}$ The higher the value of these variables, the greater the expected inflows. For debt security inflows, the results show that an increase in real GDP per capita growth reduces debt security inflows (Table 5A, column A). When a country grows healthily, and other types of capital inflows increase, there is less need to issue debt. The ratio of trade to GDP as a measure of an economy's openness to trade (trade_gdpi $)_{i}$ and political risk $\left(P R S_{i}\right)$ are positive in all types of flows, but statistically significant only in the case of direct investment inflows (Table 3A, column A). This suggests trade openness and good governance tend to be more important for attracting direct investment inflows than other inflows. By contrast, exchange rates, especially the nominal exchange rate, are significant for all types of capital inflows, except direct investment (Table $3 A)$. For direct investment inflows, changes in real not nominal exchange rates matter for affecting these inflows. External risks, proxied by the Volatility Index (VIX), lower inflows, especially debt securities (Table 5A, column A).

For capital outflow restrictions, the results show that it is only other investment outflow restrictions that effectively reduce other investment outflows. Column $A$ in Table $5 B$ shows the negative and statistical significance of coefficients associated with restrictions on other investment outflows $\left(\mathrm{CRO}_{\text {other }}\right)$. This result also implies that loosening other investment outflow restrictions, which are in place in Malaysia and some other countries in the region, helps to stimulate more, other investment outflows. No asymmetric effect, in which the effect of tightening capital controls may be different from loosening controls, is found in these restrictions (Table 6B, column B). Note that a negative sign of capital restriction coefficient is also found for direct investment, but not in equity and debt securities, although it is statistically insignificant.

For equity and debt securities, the results show that coefficients associated with their restrictions have a positive but statistically insignificant sign. (Tables $4 \mathrm{~B}$ and $5 \mathrm{~B}$, columns $\mathrm{A}$ ). The positive sign may be because restrictions on capital outflows, especially in these two flows, are seen as sending a signal to market participants about the possibility of financial instability or capital flight. It seems that for equity and debt securities, there is no clear difference between residents and nonresidents in terms of responding to restrictions on capital outflows (Tables $4 \mathrm{~B}$ and $5 \mathrm{~B}$, columns $B$ ). The results also indicate that in almost all types of assets, capital inflow restrictions do not have a significant effect on capital outflows. Equity is the exception. Here, equity inflow restrictions (relaxation) effectively reduce (stimulate) equity outflows. This could be because of the very nature of the stock market where buying and selling shares tend to be easier than trading in other types of assets. So, if inflows can enter a country easily, more outflows are expected. Financial integration could also stimulate residents to invest in other stock markets. Column D in Table 4B shows a negative and significant coefficient associated with $C R I_{\text {equity }}$ in equity outflow equations.

19 Note that for other investment inflows, real GDP growth performs better in explaining inflows in the region. 
Substitution effects in capital controls are found only in the case of equity and debt securities; that is, in restrictions on equity outflows that result in higher debt security outflows. Column $\mathrm{E}$ in Table $5 \mathrm{~B}$ shows the positive and significant coefficient of $\mathrm{CRO}_{\text {equity }}$ in the debt outflow equation. By contrast, complementarity is found between equity and direct investments. The results show a negative and statistical significance of the coefficient associated with $C R \mathrm{O}_{\text {direct }}$ in the equity outflow equation, implying that relaxing controls on direct investment outflows increases equity outflows (Table 4B, column E). Allowing residents to engage in more direct investment outflows, which are characterized by more mergers and acquisitions, stimulates others to purchase those shares (that is, equity outflows). ${ }^{20}$

Table 5: Effectiveness of Capital Controls on Debt Security Flows

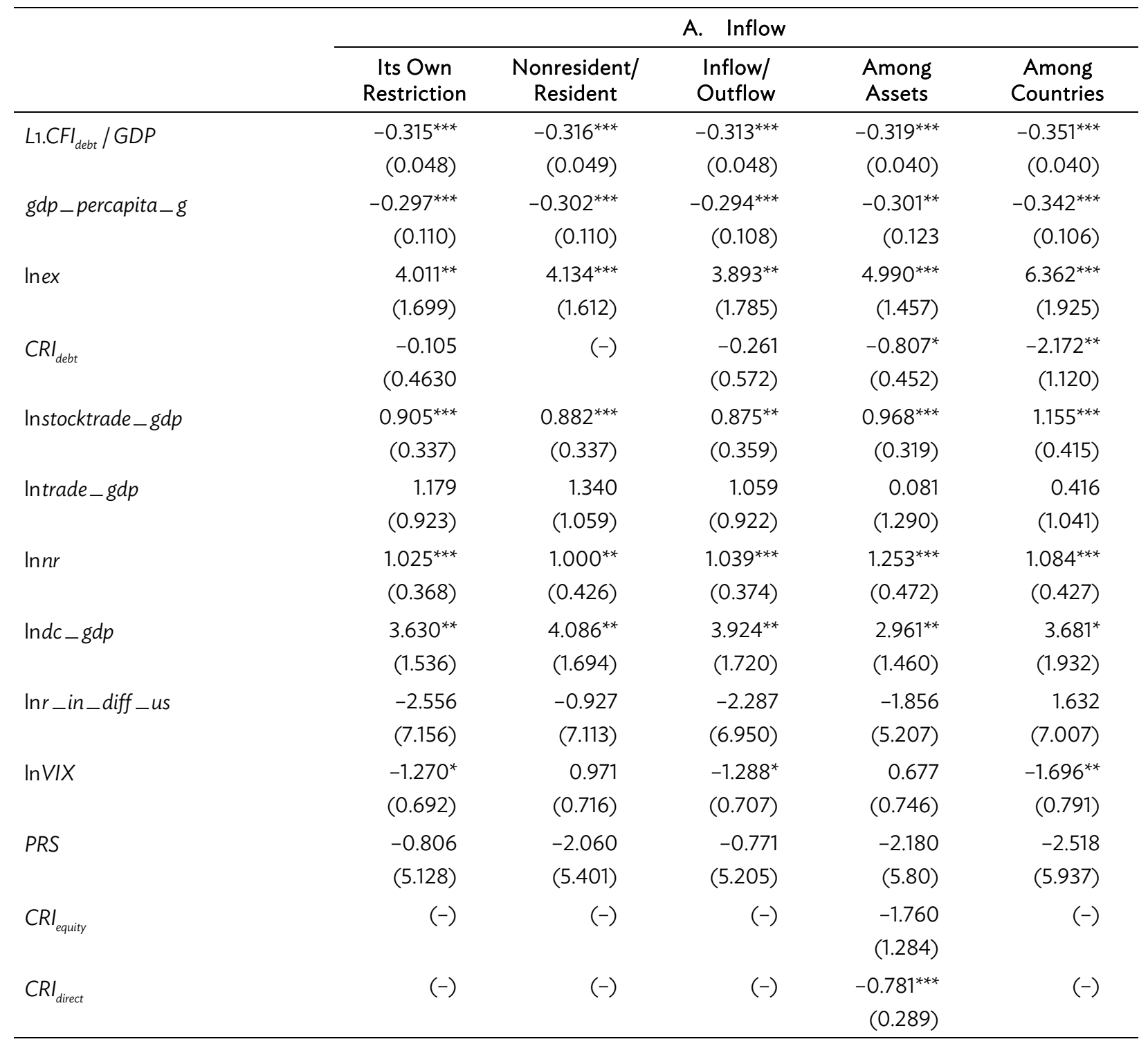

continued on next page

20 Jongwanich (2017) shows that during 2013-2015 about 50\% of direct investment outflows were from mergers and acquisitions. 
Table 5 continued

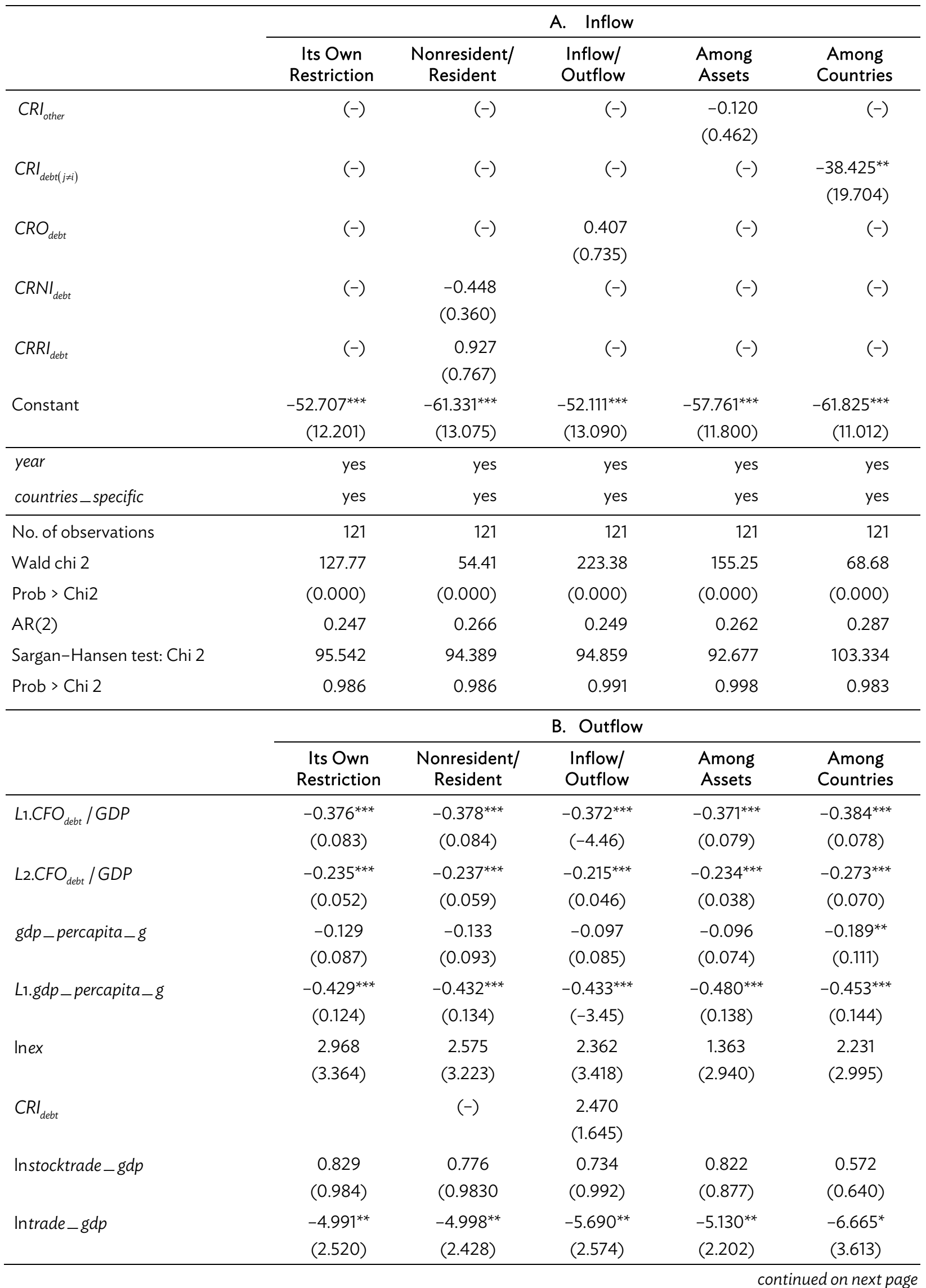


Table 5 continued

\begin{tabular}{|c|c|c|c|c|c|}
\hline & \multicolumn{5}{|c|}{ B. Outflow } \\
\hline & $\begin{array}{l}\text { Its Own } \\
\text { Restriction }\end{array}$ & $\begin{array}{l}\text { Nonresident/ } \\
\text { Resident }\end{array}$ & $\begin{array}{l}\text { Inflow/ } \\
\text { Outflow }\end{array}$ & $\begin{array}{l}\text { Among } \\
\text { Assets }\end{array}$ & $\begin{array}{l}\text { Among } \\
\text { Countries }\end{array}$ \\
\hline \multirow[t]{2}{*}{$\ln n r$} & $-2.223^{* *}$ & $-2.156^{* *}$ & $-2.444^{* *}$ & $-2.273^{* *}$ & $-2.194^{* *}$ \\
\hline & $(0.985)$ & $(0.986)$ & $(-2.32)$ & $(1.078)$ & $(1.030)$ \\
\hline \multirow[t]{2}{*}{$\ln d c_{-} g d p$} & 2.022 & 1.812 & 1.835 & 2.515 & 2.411 \\
\hline & $(4.616)$ & $(4.410)$ & $(4.467)$ & $(4.243)$ & $(4.157)$ \\
\hline \multirow[t]{2}{*}{$\ln r \_i n \_d i f f \_u s$} & 16.470 & 13.773 & 5.853 & 6.990 & 14.357 \\
\hline & $(12.175)$ & $(12.498)$ & $(0.41)$ & $(14.976)$ & (12.851) \\
\hline \multirow[t]{2}{*}{$\ln V I X$} & $2.866^{* *}$ & $2.691^{* *}$ & 2.988 & $2.362^{*}$ & -1.073 \\
\hline & $(1.269)$ & $(1.186)$ & $(1.342)^{* *}$ & $(1.365)$ & $(4.022)$ \\
\hline \multirow[t]{2}{*}{ PRS } & 2.464 & 0.520 & 3.891 & $5.297^{*}$ & 1.413 \\
\hline & $(4.529)$ & $(6.917)$ & $(4.274)$ & $(2.900)$ & $(5.710)$ \\
\hline$C R I_{\text {equity }}$ & $(-)$ & $(-)$ & $(-)$ & $(-)$ & $(-)$ \\
\hline \multirow[t]{2}{*}{$\mathrm{CRO}_{\text {equity }}$} & $(-)$ & $(-)$ & $(-)$ & $2.504^{* *}$ & $(-)$ \\
\hline & & & & $(1.098)$ & \\
\hline \multirow{2}{*}{$\mathrm{CRO}_{\text {other }}$} & $(-)$ & $(-)$ & $(-)$ & 0.030 & $(-)$ \\
\hline & & & & $(1.526)$ & \\
\hline \multirow{2}{*}{$C R O_{\text {debt }(j \neq i)}$} & $(-)$ & $(-)$ & $(-)$ & $(-)$ & -36.806 \\
\hline & & & & & $(42.727)$ \\
\hline \multirow[t]{2}{*}{$\mathrm{CRO}_{\text {direct }}$} & $(-)$ & $(-)$ & $(-)$ & 1.063 & $(-)$ \\
\hline & & & & $(0.751)$ & \\
\hline \multirow[t]{2}{*}{$C R O_{\text {debt }}$} & 2.276 & $(-)$ & 1.456 & 2.765 & -0.741 \\
\hline & $(1.782)$ & & $(1.767)$ & $(2.085)$ & $(4.481)$ \\
\hline \multirow[t]{2}{*}{$C R N O_{d e b t}$} & $(-)$ & 1.571 & $(-)$ & $(-)$ & $(-)$ \\
\hline & & $(2.077)$ & & & \\
\hline \multirow{2}{*}{$\mathrm{CRRO}_{\text {debt }}$} & $(-)$ & 0.926 & $(-)$ & $(-)$ & $(-)$ \\
\hline & & (1.017) & & & \\
\hline \multirow[t]{2}{*}{ Constant } & -15.235 & -9.140 & -8.723 & -3.037 & 20.478 \\
\hline & $(39.407)$ & $(36.179)$ & $(39.315)$ & $(34.349)$ & $(37.129)$ \\
\hline year & yes & yes & yes & yes & yes \\
\hline countries_specific & yes & yes & yes & yes & yes \\
\hline No. of observations & 111 & 111 & 111 & 111 & 111 \\
\hline Wald chi 2 & 98.64 & 259.47 & 166.51 & 135.53 & 54.78 \\
\hline Prob $>$ Chi2 & $(0.000)$ & $(0.000)$ & $(0.000)$ & $(0.000)$ & $(0.000)$ \\
\hline $\mathrm{AR}(2)$ & 0.165 & 0.169 & 0.157 & 0.209 & 0.197 \\
\hline Sargan-Hansen test: Chi 2 & 87.228 & 86.081 & 88.070 & 85.019 & 91.595 \\
\hline Prob > Chi 2 & 0.971 & 0.972 & 0.982 & 0.002 & 0.979 \\
\hline
\end{tabular}


Table 6: Effectiveness of Capital Controls on Other Investment Flows

\begin{tabular}{|c|c|c|c|c|}
\hline & \multicolumn{4}{|c|}{ A. Inflow } \\
\hline & $\begin{array}{l}\text { Its Own } \\
\text { Restriction }\end{array}$ & Inflow/Outflow & Among Assets & Among Countries \\
\hline L1.CFI $_{\text {other }} / G D P$ & $\begin{array}{r}-0.293^{* * *} \\
(0.050)\end{array}$ & $\begin{array}{r}-0.287^{* * *} \\
(0.048)\end{array}$ & $\begin{array}{r}-0.296^{* * *} \\
(0.051)\end{array}$ & $\begin{array}{r}-0.312^{* * *} \\
(0.060)\end{array}$ \\
\hline$g d p-g$ & $\begin{array}{l}0.942^{* *} \\
(0.430)\end{array}$ & $\begin{array}{l}0.885^{* *} \\
(0.433)\end{array}$ & $\begin{array}{l}0.827^{* *} \\
(0.369)\end{array}$ & $\begin{array}{c}0.900^{* * *} \\
(0.344)\end{array}$ \\
\hline Inex & $\begin{array}{r}21.971^{*} \\
(12.157)\end{array}$ & $\begin{array}{r}23.216^{*} \\
(12.342)\end{array}$ & $\begin{array}{r}26.655^{*} \\
(14.682)\end{array}$ & $\begin{array}{r}25.676^{*} \\
(15.464)\end{array}$ \\
\hline Instocktrade_gdp & $\begin{array}{c}2.653^{* *} \\
(1.158)\end{array}$ & $\begin{array}{r}2.650^{* *} \\
(1.119)\end{array}$ & $\begin{array}{l}2.679^{* *} \\
(1.305)\end{array}$ & $\begin{array}{l}3.064^{*} \\
(1.801)\end{array}$ \\
\hline Instocktrade_gdp & $\begin{array}{r}9.400 \\
(6.632)\end{array}$ & $\begin{array}{r}7.561 \\
(5.372)\end{array}$ & $\begin{array}{r}5.950 \\
(5.545)\end{array}$ & $\begin{array}{r}6.415 \\
(4.790)\end{array}$ \\
\hline $\ln n r$ & $\begin{array}{l}5.610^{* *} \\
(2.825)\end{array}$ & $\begin{array}{l}5.651^{1 *} \\
(2.743)\end{array}$ & $\begin{array}{l}6.817^{* *} \\
(2.950)\end{array}$ & $\begin{array}{l}5.529^{* *} \\
(2.290)\end{array}$ \\
\hline$L 1 . \ln d c_{-} g d p$ & $\begin{array}{r}-14.244 \\
(8.871)\end{array}$ & $\begin{array}{l}-13.76^{*} \\
(8.341)\end{array}$ & $\begin{array}{r}-15.670^{*} \\
(9.308)\end{array}$ & $\begin{array}{r}-9.351 \\
(6.585)\end{array}$ \\
\hline $\ln r \_i n \_d i f f \_u s$ & $\begin{array}{r}23.123 \\
(37.764)\end{array}$ & $\begin{array}{r}23.033 \\
(37.327)\end{array}$ & $\begin{array}{r}29.326 \\
(33.587)\end{array}$ & $\begin{array}{r}26.521 \\
(33.213)\end{array}$ \\
\hline $\ln V I X$ & $\begin{array}{r}6.081 \\
(3.940)\end{array}$ & $\begin{array}{r}5.234 \\
(3.689)\end{array}$ & $\begin{array}{r}7.616^{*} \\
(4.389)\end{array}$ & $\begin{array}{r}6.452 \\
(4.551)\end{array}$ \\
\hline PRS & $\begin{array}{l}-54.949 \\
(38.727)\end{array}$ & $\begin{array}{r}-51.767 \\
(37.804)\end{array}$ & $\begin{array}{l}-69.306 \\
(47.189)\end{array}$ & $\begin{array}{l}-60.941^{*} \\
(37.723)\end{array}$ \\
\hline$C R I_{\text {direct }}$ & $(-)$ & $(-)$ & $\begin{array}{r}-1.034 \\
(2.265)\end{array}$ & $(-)$ \\
\hline$C R I_{\text {equity }}$ & $(-)$ & $(-)$ & $\begin{array}{r}-8.214 \\
(5.948)\end{array}$ & $(-)$ \\
\hline$C R I_{d e b t}$ & $(-)$ & & $\begin{array}{r}-6.811 \\
(7.545)\end{array}$ & $(-)$ \\
\hline$C R I_{\text {other }}$ & $\begin{array}{l}-2.278 \\
(1.684)\end{array}$ & $\begin{array}{r}0.452 \\
(6.113)\end{array}$ & $\begin{array}{r}-1.663 \\
(2.395)\end{array}$ & $\begin{array}{r}-13.887^{* *} \\
(-2.33)\end{array}$ \\
\hline$C R I_{\text {other }(j \neq i)}$ & $(-)$ & $(-)$ & $(-)$ & $\begin{array}{r}-85.784^{* *} \\
(37.792)\end{array}$ \\
\hline$C R O_{\text {other }}$ & $(-)$ & $\begin{array}{l}-2.540 \\
(6.387)\end{array}$ & $(-)$ & $(-)$ \\
\hline Constant & $\begin{array}{r}-212.386^{* * *} \\
(90.731)\end{array}$ & $\begin{array}{r}-217.123^{* * *} \\
(91.396)\end{array}$ & $\begin{array}{r}-226.062^{* *} \\
(99.717)\end{array}$ & $\begin{array}{r}-225.294^{* *} \\
(115.552)\end{array}$ \\
\hline year & yes & yes & yes & yes \\
\hline countries_specific & yes & yes & yes & yes \\
\hline
\end{tabular}


Table 6 continued

\begin{tabular}{|c|c|c|c|c|c|}
\hline & \multicolumn{5}{|c|}{ A. Inflow } \\
\hline & $\begin{array}{l}\text { Its Own } \\
\text { Restriction }\end{array}$ & \multicolumn{2}{|c|}{ Inflow/Outflow } & Among Assets & Among Countries \\
\hline No. of observations & 134 & \multicolumn{2}{|c|}{134} & 134 & 134 \\
\hline Wald chi 2 & 43.84 & \multicolumn{2}{|c|}{182.49} & 156.85 & 51.61 \\
\hline Prob > Chi2 & $(0.000)$ & \multicolumn{2}{|c|}{$(0.000)$} & $(0.000)$ & $(0.000)$ \\
\hline $\operatorname{AR}(2)$ & 0.828 & \multicolumn{2}{|c|}{0.843} & 0.705 & 0.403 \\
\hline Sargan-Hansen test: Chi 2 & 104.991 & \multicolumn{2}{|c|}{106.557} & 105.132 & 102.419 \\
\hline \multirow[t]{3}{*}{ Prob $>$ Chi 2} & 0.986 & \multicolumn{2}{|c|}{0.984} & 0.997 & 0.997 \\
\hline & \multicolumn{5}{|c|}{ B. Outflow } \\
\hline & $\begin{array}{l}\text { Its Own } \\
\text { Restriction }\end{array}$ & Asymmetric & $\begin{array}{l}\text { Inflow/ } \\
\text { Outflow }\end{array}$ & Among Assets & $\begin{array}{l}\text { Among } \\
\text { Countries }\end{array}$ \\
\hline$L_{1} . C F O_{\text {other }} / G D P$ & $\begin{array}{r}-0.040^{* *} \\
(0.015)\end{array}$ & $\begin{array}{l}-0.046 \\
(0.016)\end{array}$ & $\begin{array}{l}-0.029^{*} \\
(0.016)\end{array}$ & $\begin{array}{l}-0.066 \\
(0.055)\end{array}$ & $\begin{array}{l}-0.113^{* *} \\
(0.055)\end{array}$ \\
\hline$g d p \_$percapita_g & $\begin{array}{l}0.983^{* * *} \\
(0.372)\end{array}$ & $\begin{array}{l}0.922^{* * *} \\
(0.359)\end{array}$ & $\begin{array}{c}0.946^{* * *} \\
(0.357)\end{array}$ & $\begin{array}{l}0.7983^{* *} \\
(0.341)\end{array}$ & $\begin{array}{l}0.991^{* * *} \\
(0.300)\end{array}$ \\
\hline Inex & $\begin{array}{c}16.043^{* *} \\
(6.597)\end{array}$ & $\begin{array}{r}16.583^{* * *} \\
(6.683)\end{array}$ & $\begin{array}{l}16.524^{* *} \\
(7.240)\end{array}$ & $\begin{array}{r}8.128 \\
(10.934)\end{array}$ & $\begin{array}{l}27.896^{* *} \\
(14.036)\end{array}$ \\
\hline $\mathrm{CRO}_{\text {other }}$ & $\begin{array}{l}-3.203^{*} \\
(1.840)\end{array}$ & $\begin{array}{l}-3.374 \\
(2.149)\end{array}$ & $\begin{array}{r}-4.716 \\
(4.993)\end{array}$ & $\begin{array}{l}-2.809 \\
(2.203)\end{array}$ & $\begin{array}{r}-24.980^{* * *} \\
(8.275)\end{array}$ \\
\hline Instocktrade_gdp & $\begin{array}{l}2.163^{* *} \\
(1.022)\end{array}$ & $\begin{array}{l}2.744^{*} \\
(1.615)\end{array}$ & $\begin{array}{c}1.798^{*} \\
(1.026)\end{array}$ & $\begin{array}{r}2.462 \\
(1.770)\end{array}$ & $\begin{array}{l}2.959^{*} \\
(1.797)\end{array}$ \\
\hline Intrade_gdp & $\begin{array}{r}8.135 \\
(6.219)\end{array}$ & $\begin{array}{r}8.053 \\
(6.547)\end{array}$ & $\begin{array}{r}6.901 \\
(6.912)\end{array}$ & $\begin{array}{l}10.676 \\
(6.675)\end{array}$ & $\begin{array}{l}-7.448 \\
(6.788)\end{array}$ \\
\hline $\ln n r$ & $\begin{array}{r}0.346 \\
(2.703)\end{array}$ & $\begin{array}{l}-0.109 \\
(2.754)\end{array}$ & $\begin{array}{r}0.178 \\
(2.503)\end{array}$ & $\begin{array}{r}0.119 \\
(2.328)\end{array}$ & $\begin{array}{r}1.621 \\
(2.381)\end{array}$ \\
\hline$L 1 . \ln d c_{-} g d p$ & $\begin{array}{r}-14.967^{* * *} \\
(5.528)\end{array}$ & $\begin{array}{r}-15.119^{* * *} \\
(5.505)\end{array}$ & $\begin{array}{r}-15.802^{* * *} \\
(5.771)\end{array}$ & $\begin{array}{r}-15.214^{*} \\
(8.142)\end{array}$ & $\begin{array}{l}-3.359 \\
(3.594)\end{array}$ \\
\hline $\ln r \_i n \_d i f f \_u s$ & $\begin{array}{r}26.135 \\
(31.795)\end{array}$ & $\begin{array}{r}22.052 \\
(28.552)\end{array}$ & $\begin{array}{r}21.367 \\
(31.164)\end{array}$ & $\begin{array}{r}-16.313 \\
(80.396)\end{array}$ & $\begin{array}{r}37.167 \\
(33.333)\end{array}$ \\
\hline $\ln V I X$ & $\begin{array}{r}1.047 \\
(4.563)\end{array}$ & $\begin{array}{r}0.712 \\
(3.371)\end{array}$ & $\begin{array}{r}0.938 \\
(2.199)\end{array}$ & $\begin{array}{r}2.056 \\
(7.358)\end{array}$ & $\begin{array}{r}1.721 \\
(2.783)\end{array}$ \\
\hline PRS & $\begin{array}{r}-39.415 \\
(43.325)\end{array}$ & $\begin{array}{l}-41.128 \\
(43.931)\end{array}$ & $\begin{array}{l}-29.458 \\
(36.386)\end{array}$ & $\begin{array}{r}-31.494 \\
(38.253)\end{array}$ & $\begin{array}{l}-47.423 \\
(44.895)\end{array}$ \\
\hline $\mathrm{CRO}_{\text {other }}$ & $(-)$ & $(-)$ & $\begin{array}{r}1.913 \\
(6.122)\end{array}$ & $(-)$ & $(-)$ \\
\hline
\end{tabular}




\begin{tabular}{|c|c|c|c|c|c|}
\hline & & & B. Outflon & & \\
\hline & $\begin{array}{c}\text { Its Own } \\
\text { Restriction }\end{array}$ & Asymmetric & $\begin{array}{l}\text { Inflow/ } \\
\text { Outflow }\end{array}$ & Among Assets & $\begin{array}{l}\text { Among } \\
\text { Countries }\end{array}$ \\
\hline $\mathrm{CRO}_{\text {direct }}$ & $(-)$ & $(-)$ & $(-)$ & $\begin{array}{r}1.138 \\
(1.626)\end{array}$ & $(-)$ \\
\hline$C R O_{\text {debt }}$ & $(-)$ & $(-)$ & $(-)$ & $\begin{array}{l}-5.336 \\
(7.125)\end{array}$ & $(-)$ \\
\hline$C R O_{\text {other }(j \neq i)}$ & $(-)$ & $(-)$ & $(-)$ & $(-)$ & $\begin{array}{r}-166.183^{* * *} \\
(57.722)\end{array}$ \\
\hline$C R O_{\text {equity }}$ & $(-)$ & $(-)$ & $(-)$ & $\begin{array}{r}11.568 \\
(17.969)\end{array}$ & $(-)$ \\
\hline$C R O_{\text {other }} \cdot D^{\text {tight }}$ & $(-)$ & $\begin{array}{r}0.243 \\
(2.919)\end{array}$ & $(-)$ & $(-)$ & $(-)$ \\
\hline$C R O_{\text {other }} \cdot D^{\text {loosen }}$ & $(-)$ & $\begin{array}{l}-3.520 \\
(2.274)\end{array}$ & $(-)$ & $(-)$ & $(-)$ \\
\hline Constant & $\begin{array}{r}-115.083^{* *} \\
(49.259)\end{array}$ & $\begin{array}{r}-116.374^{* *} \\
(48.024)\end{array}$ & $\begin{array}{r}-117.016^{* * *} \\
(42.153)\end{array}$ & $\begin{array}{l}-66.417 \\
(77.621)\end{array}$ & $\begin{array}{r}-118.244^{* *} \\
(67.294)\end{array}$ \\
\hline year & yes & yes & yes & yes & yes \\
\hline countries_specific & yes & yes & yes & yes & yes \\
\hline No. of observations & 134 & 134 & 134 & 134 & 134 \\
\hline Wald chi 2 & 67.02 & 75.71 & 50.78 & 40.17 & 249.75 \\
\hline Prob > Chi2 & $(0.000)$ & $(0.000)$ & $(0.000)$ & $(0.000)$ & $(0.000)$ \\
\hline $\mathrm{AR}(2)$ & 0.507 & 0.505 & 0.526 & 0.343 & 0.303 \\
\hline Sargan-Hansen test: Chi 2 & 116.093 & 114.955 & 116.164 & 115.987 & 112.008 \\
\hline Prob $>$ Chi 2 & 0.891 & 0.915 & 0.929 & 0.964 & 0.955 \\
\hline
\end{tabular}

Interestingly, the study shows that capital restrictions imposed by other countries not only influence capital inflows but also capital outflows. When other countries impose restrictions on debt securities and other investment outflows, these outflows reduce within a country. Tables $5 \mathrm{~B}$ and $6 \mathrm{~B}$, columns $F$ show that the coefficients associated with $C R I_{\text {debt, }(j \neq i) t}, C R I_{\text {other, }(j \neq i) t}$ are negative in and statistically significant for debts and other investment outflows. This shows complementarity between these flows across the region, because once other emerging Asian countries impose outflow restrictions, this potentially signifies a loss of confidence, and the possibility of capital flight and financial instability within a particular country. This could spread throughout the region, thereby reducing debt and other investment outflows from that country. 
By contrast, the results indicate substitution among equity outflows in the region. When other countries impose equity outflow restrictions, equity outflows increase; that is, there is a positive and significant coefficient of $C R I_{\text {equity, }(j \neq i) t}$ in the equity outflow equation (Table $4 \mathrm{~B}$, column $\mathrm{F}$ ). Lower equity prices, which could be caused by less demand from other countries, may help to explain substitutions among equity outflows in the region. Note there is no significant effect in the direct investment outflow restrictions imposed by other countries on the direct investment of a country (Table 3B, column F). Other variables, especially economic stage of development, are more important.

For other control variables in the outflow equations, real GDP per capita growth matters for stimulating capital outflows across almost all types of capital (Table 3B, column A). ${ }^{21}$ An exception was found with debt security outflows, where real GDP per capita growth resulted in a reduction in these outflows. This may be because residents want to invest more in domestic securities. The ratio of the natural resource endowment of a country $\left(n r_{i}\right)$, and the ratio of trade to GDP as a measure of an economy's openness to trade (trade_gdp), tends to be more important for promoting direct investment outflows than other factors. External risks, proxied by the Volatility Index (VIX), lower capital outflows from the region. But higher global risks result in more debt security outflows (Table 5B, column A). This may be because investors want to hold safe assets during global uncertainty, such as government bonds issued by developed countries.

\section{B. Effectiveness of Capital Controls on Composition Changes}

Table 7 shows the results on the effectiveness of capital restrictions in changing the composition of capital inflows toward FDI. Column $A$ shows the results when only capital inflow restrictions are included (equation 8); columns $B$ and $C$ show the findings when the substitution effects of capital inflow restrictions in emerging Asian countries are tested. The results indicate that in changing the composition of capital inflows toward FDI, economic fundamentals are more important than capital control policy. As column A shows, only restrictions on debt securities are statistically significant in this regard. Going by the findings in the previous section, this may be because restrictions on debt securities reduce equity inflows even though direct investment and equity are complementary. These restrictions help to increase the proportion of direct investments to total capital inflows.

The findings in column B of Table 7 show that while the direct investment inflow restrictions imposed by other countries in emerging Asia can stimulate more direct investment inflows into the region, as shown in the previous section, the restrictions do not increase the proportion of direct investment inflows to total capital inflows. Note that other types of inflow restrictions imposed by other countries are also insignificant in influencing the composition changes of capital inflows (Table 7, column C). To increase the proportion of direct investment inflows, economic growth ( $g d p \_$percapita_gi $)$, financial development_-both in financial institutions ( $d c \_g d p$ ) and capital markets (stocktrade_gdp) - and good governance (PRS) are all crucial. All these variables are positive and statistically significant. Real interest rate differentials and nominal exchange rates could also influence the composition; that is, high real interest rate and the depreciation of exchange rates reduce the proportion of FDI inflows.

${ }^{21}$ Note that for direct investment outflows, real GDP per capita performs better in explaining outflows of direct investment in the region. This could be because, as suggested by Dunning (1986), the level of a country's development, which is most efficiently measured by real GDP per capita (instead of growth), matters for a country in conducting outward FDI. 
40 | ADB Economics Working Paper Series No. 578

Table 7: Effectiveness of Capital Controls: Composition Changes toward Direct Investment

\begin{tabular}{|c|c|c|c|}
\hline & A & B & $C$ \\
\hline L1.CFI $\left.\right|_{\text {direct }} /$ totalinflow & $\begin{array}{r}-0.135 \\
(0.092)\end{array}$ & $\begin{array}{l}-0.096 \\
(0.089)\end{array}$ & $\begin{array}{r}-0.125 \\
(0.090)\end{array}$ \\
\hline$g d p_{-}$percapita_g & $\begin{array}{c}0.014^{* *} \\
(0.006)\end{array}$ & $\begin{array}{c}0.013^{* *} \\
(0.006)\end{array}$ & $\begin{array}{l}0.010^{* * *} \\
(0.006)\end{array}$ \\
\hline Inex & $\begin{array}{r}-4.445^{* *} \\
(0.221)\end{array}$ & $\begin{array}{l}-0.298 \\
(0.186)\end{array}$ & $\begin{array}{c}-0.393^{* *} \\
(0.200)\end{array}$ \\
\hline$C R I_{\text {direct }}$ & $\begin{array}{r}0.075 \\
(0.047)\end{array}$ & $\begin{array}{r}0.099 \\
(0.062)\end{array}$ & $\begin{array}{l}-0.028 \\
(0.176)\end{array}$ \\
\hline$C R I_{\text {equity }}$ & $\begin{array}{r}0.098 \\
(0.086)\end{array}$ & $(-)$ & $(-)$ \\
\hline$C R I_{d e b t}$ & $\begin{array}{l}0.195^{*} \\
(0.111)\end{array}$ & $(-)$ & $(-)$ \\
\hline$C R I_{\text {other }}$ & $\begin{array}{r}0.023 \\
(0.047)\end{array}$ & $(-)$ & $(-)$ \\
\hline$C R I_{\text {direct }(j \neq i)}$ & $(-)$ & $\begin{array}{r}0.489 \\
(0.440)\end{array}$ & $\begin{array}{l}-3.285 \\
(3.277)\end{array}$ \\
\hline$C R I_{\text {equity }(j \neq i)}$ & $(-)$ & $(-)$ & $\begin{array}{r}-1.241 \\
(1.232)\end{array}$ \\
\hline$C R I_{d e b t(j \neq i)}$ & $(-)$ & $(-)$ & $\begin{array}{l}-3.609 \\
(3.751)\end{array}$ \\
\hline$C R I_{\text {other }(j \neq i)}$ & $(-)$ & $(-)$ & $\begin{array}{l}-2.845 \\
(2.561)\end{array}$ \\
\hline Instocktrade_gdp & $\begin{array}{l}0.070^{* *} \\
(0.027)\end{array}$ & $\begin{array}{l}0.062^{* *} \\
(0.025)\end{array}$ & $\begin{array}{r}0.064^{* * *} \\
(0.024)\end{array}$ \\
\hline Intrade_gdp & $\begin{array}{r}0.009 \\
(0.112)\end{array}$ & $\begin{array}{r}-0.085 \\
(0.094)\end{array}$ & $\begin{array}{l}-0.143 \\
(0.113)\end{array}$ \\
\hline $\ln n r$ & $\begin{array}{l}-0.030 \\
(0.045)\end{array}$ & $\begin{array}{l}-0.006 \\
(0.034)\end{array}$ & $\begin{array}{l}-0.028 \\
(0.041)\end{array}$ \\
\hline Indc_gdp & $\begin{array}{l}0.302^{* *} \\
(0.163)\end{array}$ & $\begin{array}{c}0.331^{*} \\
(0.205)\end{array}$ & $\begin{array}{r}0.407 \\
(0.266)\end{array}$ \\
\hline $\ln r \_$in_diff_us & $\begin{array}{c}-1.749^{* *} \\
(0.727)\end{array}$ & $\begin{array}{c}-1.541^{* *} \\
(0.781)\end{array}$ & $\begin{array}{l}-1.359^{*} \\
(0.850)\end{array}$ \\
\hline L1. InVIX & $\begin{array}{r}-0.051 \\
(0.093)\end{array}$ & $\begin{array}{r}0.037 \\
(0.081)\end{array}$ & $\begin{array}{r}-1.359 \\
(0.850)\end{array}$ \\
\hline PRS & $\begin{array}{l}2.253^{* * *} \\
(0.948)\end{array}$ & $\begin{array}{c}2.199^{* * *} \\
(0.811)\end{array}$ & $\begin{array}{l}2.522^{* *} \\
(1.057)\end{array}$ \\
\hline Constant & $\begin{array}{r}1.731 \\
(1.221)\end{array}$ & $\begin{array}{r}0.391 \\
(1.125)\end{array}$ & $\begin{array}{l}4.831^{* *} \\
(2.876)\end{array}$ \\
\hline
\end{tabular}


Table 7 continued

\begin{tabular}{lcrr}
\hline & A & B & C \\
\hline year & yes & yes & yes \\
countries_specific & yes & yes & yes \\
\hline No. of observations & 138 & 138 & 138 \\
Wald chi 2 & 43.20 & 56.95 & 47.97 \\
Prob > Chi2 & $(0.000)$ & $(0.00)$ & $(0.000)$ \\
AR(2) & 0.931 & 0.922 & 0.589 \\
Sargan-Hansen test: Chi 2 & 111.447 & 105.972 & 116.519 \\
Prob > Chi 2 & 0.992 & 0.988 & 0.992 \\
\hline
\end{tabular}

Notes: Values in parentheses are robust standard errors. ${ }^{* *}=$ significance at $1 \%$ level, ${ }^{* *}=5 \%$, and ${ }^{*}=10 \%$. $(-)$ refers to no presence of this variable in an estimation.

Source: Author's estimates.

\section{Effectiveness of Capital Controls: Relieving Pressure on Real Exchange Rates}

Table 8 shows the results on the effectiveness of capital controls in relieving pressures on real exchange rates. Columns $A$ and $C$ show the effects of capital inflows and outflows, and the effects of capital inflow restrictions on real exchange rates where $A$ is the real effective exchange rate and $C$ is the bilateral exchange rate with the US dollar. Columns B and D show the effectiveness of capital controls when both capital inflow and outflow restrictions are included. Note that the results from both measures involving real exchange rates are similar.

Table 8: Effectiveness of Capital Controls: Real Exchange Rate

\begin{tabular}{|c|c|c|c|c|}
\hline & \multicolumn{2}{|c|}{ Real Effective Exchange Rate } & \multicolumn{2}{|c|}{ Bilateral Exchange Rate } \\
\hline & A & B & C & D \\
\hline L1.lrer & $\begin{array}{r}0.696^{* * *} \\
(0.073)\end{array}$ & $\begin{array}{r}0.690^{* * *} \\
(0.091)\end{array}$ & $\begin{array}{l}0.689^{* * *} \\
(0.069)\end{array}$ & $\begin{array}{l}0.689^{* * *} \\
(0.089)\end{array}$ \\
\hline$C F I_{\text {direct }} / \mathrm{GDP}$ & $\begin{array}{l}-0.019^{* *} \\
(0.000)\end{array}$ & $\begin{array}{c}-0.002^{* * *} \\
(0.000)\end{array}$ & $\begin{array}{r}-0.002^{* * *} \\
(0.000)\end{array}$ & $\begin{array}{r}-0.003^{* * *} \\
(0.001)\end{array}$ \\
\hline$\left(\left.C F\right|_{\text {direct }} / G D P\right) \cdot C R I_{\text {direct }}$ & $\begin{array}{l}0.0149^{* *} \\
(0.005)\end{array}$ & $\begin{array}{l}0.015^{* * *} \\
(0.005)\end{array}$ & $\begin{array}{l}0.014^{* * *} \\
(0.005)\end{array}$ & $\begin{array}{l}0.015^{* * *} \\
(0.005)\end{array}$ \\
\hline$C F I_{\text {equity }} / G D P$ & $\begin{array}{l}-0.004^{*} \\
(0.002)\end{array}$ & $\begin{array}{l}-0.003 \\
(0.002)\end{array}$ & $\begin{array}{c}-0.052^{* *} \\
(0.002)\end{array}$ & $\begin{array}{r}-0.004^{* *} \\
(0.003)\end{array}$ \\
\hline$\left(C F I_{\text {equity }} / G D P\right) \cdot C R I_{\text {equity }}$ & $\begin{array}{l}-0.003 \\
(0.005)\end{array}$ & $\begin{array}{l}-0.003 \\
(0.005)\end{array}$ & $\begin{array}{l}-0.004 \\
(0.004)\end{array}$ & $\begin{array}{l}-0.005 \\
(0.005)\end{array}$ \\
\hline$C F I_{d e b t} / G D P$ & $\begin{array}{l}-0.004^{*} \\
(0.002)\end{array}$ & $\begin{array}{l}-0.005^{*} \\
(0.002)\end{array}$ & $\begin{array}{r}0.003 \\
(0.002)\end{array}$ & $\begin{array}{l}-0.005^{*} \\
(0.003)\end{array}$ \\
\hline$\left(C F I_{d e b t} / G D P\right) \cdot C R I_{d e b t}$ & $\begin{array}{r}0.013 \\
(0.009)\end{array}$ & $\begin{array}{c}0.019^{* *} \\
(0.009)\end{array}$ & $\begin{array}{r}0.012 \\
(0.009)\end{array}$ & $\begin{array}{c}0.019^{*} \\
(0.011)\end{array}$ \\
\hline $\mathrm{CFI}_{\text {other }} / \mathrm{GDP}$ & $\begin{array}{r}-0.002^{* * *} \\
(0.000)\end{array}$ & $\begin{array}{r}-0.002^{* * *} \\
(0.000)\end{array}$ & $\begin{array}{r}-0.002^{* * *} \\
(0.000)\end{array}$ & $\begin{array}{r}-0.003^{* * *} \\
(0.001)\end{array}$ \\
\hline
\end{tabular}


42 | ADB Economics Working Paper Series No. 578

Table 8 continued

\begin{tabular}{|c|c|c|c|c|}
\hline & \multicolumn{2}{|c|}{ Real Effective Exchange Rate } & \multicolumn{2}{|c|}{ Bilateral Exchange Rate } \\
\hline & $A$ & B & C & $\mathrm{D}$ \\
\hline$\left(C F I_{\text {other }} / G D P\right) \cdot C R I_{\text {other }}$ & $\begin{array}{r}0.002 \\
(0.005)\end{array}$ & $\begin{array}{r}0.002 \\
(0.004)\end{array}$ & $\begin{array}{r}0.001 \\
(0.005)\end{array}$ & $\begin{array}{r}0.001 \\
(0.004)\end{array}$ \\
\hline $\mathrm{CFO}_{\text {direct }} / \mathrm{GDP}$ & $\begin{array}{l}0.002^{* * *} \\
(0.000)\end{array}$ & $\begin{array}{l}0.003^{* * *} \\
(0.000)\end{array}$ & $\begin{array}{l}0.003^{* * *} \\
(0.000)\end{array}$ & $\begin{array}{c}0.004^{* * *} \\
(0.000)\end{array}$ \\
\hline$\left(C F O_{\text {direct }} / G D P\right) \cdot C R O_{\text {direct }}$ & $(-)$ & $\begin{array}{l}-0.011^{* *} \\
(0.005)\end{array}$ & $(-)$ & $\begin{array}{r}-0.012^{* * *} \\
(0.005)\end{array}$ \\
\hline $\mathrm{CFO}_{\text {equity }} / \mathrm{GDP}$ & $\begin{array}{l}0.002^{* *} \\
(0.001)\end{array}$ & $\begin{array}{c}0.003^{* * *} \\
(0.001)\end{array}$ & $\begin{array}{l}0.002^{*} \\
(0.001)\end{array}$ & $\begin{array}{l}0.003^{* *} \\
(0.001)\end{array}$ \\
\hline$\left(C F O_{\text {equity }} / \mathrm{GDP}\right) \cdot C R \mathrm{O}_{\text {equity }}$ & $(-)$ & $\begin{array}{r}0.005 \\
(0.003)\end{array}$ & $(-)$ & $\begin{array}{r}0.003 \\
(0.003)\end{array}$ \\
\hline $\mathrm{CFO}_{\text {debt }} / \mathrm{GDP}$ & $\begin{array}{r}0.001 \\
(0.001)\end{array}$ & $\begin{array}{r}0.002 \\
(0.001)\end{array}$ & $\begin{array}{r}0.001 \\
(0.001)\end{array}$ & $\begin{array}{r}0.002 \\
(0.002)\end{array}$ \\
\hline$\left(\mathrm{CFO}_{\text {debt }} / \mathrm{GDP}\right) \cdot \mathrm{CRO} \mathrm{O}_{\text {debt }}$ & $(-)$ & $\begin{array}{r}0.006 \\
(0.004)\end{array}$ & $(-)$ & $\begin{array}{r}0.005 \\
(0.004)\end{array}$ \\
\hline $\mathrm{CFO}_{\text {other }} / \mathrm{GDP}$ & $\begin{array}{l}0.002^{* * *} \\
(0.000)\end{array}$ & $\begin{array}{c}0.002^{* * *} \\
(0.000)\end{array}$ & $\begin{array}{c}0.002^{* * *} \\
(0.000)\end{array}$ & $\begin{array}{c}0.002^{* * *} \\
(0.000)\end{array}$ \\
\hline$\left(C F O_{\text {other }} / G D P\right) \cdot C R O_{\text {other }}$ & $(-)$ & $\begin{array}{r}-0.002 \\
(0.000)\end{array}$ & $(-)$ & $\begin{array}{r}-0.001 \\
(0.002)\end{array}$ \\
\hline Ingovcon_gdp & $\begin{array}{r}0.104 \\
(0.073)\end{array}$ & $\begin{array}{r}0.069 \\
(0.085)\end{array}$ & $\begin{array}{c}0.100^{*} \\
(0.059)\end{array}$ & $\begin{array}{r}0.074 \\
(0.076)\end{array}$ \\
\hline $\ln P R O D$ & $\begin{array}{l}-0.063^{*} \\
(0.034)\end{array}$ & $\begin{array}{l}-0.075^{*} \\
(0.039)\end{array}$ & $\begin{array}{r}-0.027 \\
(0.028)\end{array}$ & $\begin{array}{l}-0.037 \\
(-1.14)\end{array}$ \\
\hline Intot & $\begin{array}{r}-0.637 \\
(0.059)\end{array}$ & $\begin{array}{r}-0.077 \\
(0.068)\end{array}$ & $\begin{array}{r}-0.075 \\
(0.047)\end{array}$ & $\begin{array}{r}-0.091 \\
(0.059)\end{array}$ \\
\hline Intrade_gdp & $\begin{array}{l}0.153^{* * *} \\
(0.059)\end{array}$ & $\begin{array}{c}-0.146^{* *} \\
(0.061)\end{array}$ & $\begin{array}{l}0.147^{* * *} \\
(0.054)\end{array}$ & $\begin{array}{c}0.140^{* * *} \\
(0.057)\end{array}$ \\
\hline Constant & $\begin{array}{r}0.448 \\
(0.296)\end{array}$ & $\begin{array}{r}0.440 \\
(0.372)\end{array}$ & $\begin{array}{l}0.711^{* * *} \\
(0.265)\end{array}$ & $\begin{array}{c}0.585^{*} \\
(0.358)\end{array}$ \\
\hline $\begin{array}{l}\text { year } \\
\text { countries_specific }\end{array}$ & $\begin{array}{l}\text { yes } \\
\text { yes }\end{array}$ & $\begin{array}{l}\text { yes } \\
\text { yes }\end{array}$ & $\begin{array}{l}\text { yes } \\
\text { yes }\end{array}$ & $\begin{array}{l}\text { yes } \\
\text { yes }\end{array}$ \\
\hline No. of observations & 125 & 125 & 125 & 125 \\
\hline Wald chi 2 & 1850.10 & 2128.52 & 9943.36 & 3233.72 \\
\hline Prob > Chi2 & $(0.000)$ & $(0.000)$ & $(0.000)$ & $(0.000)$ \\
\hline $\operatorname{AR}(2)$ & 0.336 & 0.318 & 0.245 & 0.282 \\
\hline Sargan-Hansen test: Chi 2 & 199.108 & 177.128 & 200.800 & 176.307 \\
\hline Prob $>$ Chi 2 & $(0.347)$ & $(0.705)$ & $(0.317)$ & $(0.719)$ \\
\hline
\end{tabular}

Notes: Values in parentheses are robust standard errors. ${ }^{* *}=$ significance at $1 \%$ level, ${ }^{* *}=5 \%$, and ${ }^{*}=10 \%$. (-) refers to no presence of this variable in an estimation.

Source: Author's estimates. 
The results show that capital inflows of all types result in real exchange rate appreciation (Table 8, columns A and C). Real appreciation tends to be highest with debt security inflows, followed by equity and other investment inflows. ${ }^{22}$ Direct investment inflows lead to real appreciation, but the size tends to be the smallest. This may be because of the nature of direct investment inflows, which tend to be more stable than other forms of capital flows. And because foreign investors tend to concentrate more in tradable goods sectors and export-oriented industries, the pressure of direct investment flows on nontradable prices tend to be lower than for the other forms of capital flows. However, the real appreciation between these two flows could arise from the fact that after the Asian financial crisis, merger and acquisition activity became an important component of FDI inflows in Asia, especially in India, the PRC, and Southeast Asian nations (Hill and Jongwanich 2009). Cross-border merger and acquisitions mostly went into nontradable activities, including financial services and telecommunications. Nontradable prices therefore tended to be affected more than tradable prices, resulting in real appreciation.

Not all capital inflow restrictions help to redress real exchange rate appreciation, however. The results show that only direct investment and debt security inflow restrictions help to reduce this pressure from their corresponding capital inflows. The coefficients associated with the interaction terms between these inflows and their corresponding restrictions are positive and significant (Table 8 , columns $B$ and $D$ ). The ability of these restrictions to redress the pressure on exchange rates is because of their potential to reduce capital inflows, and the motivations corresponding to these capital inflows. As the previous section shows, direct investment and debt security inflow restrictions effectively reduce direct investment inflows. ${ }^{23}$ The insignificance of equity inflow restrictions may be because these restrictions reduce inflows, which are only slightly related to economic activities Thus, inflow restrictions involve low relative price changes.

For capital outflows, the results show that all types lead to real exchange rate depreciation, with less significance found in debt securities (Table 8 , columns $B$ and $D$ ). With direct investment outflows, cross-border mergers and acquisitions become more important (Jongwanich 2017). The productivity improvement in the tradable sector emerging from outward FDI (mostly from mergers and acquisitions) could be less, so that the depreciation, instead of appreciation, of real exchange rate occurs as a result of outward FDI investment. The results show, however, that only direct investment outflow restrictions can help relieve pressure of a real exchange rate depreciation from direct investment outflows. This is reflected by the negative and statistically significant coefficient of the interaction term between direct investment outflows and its restrictions (Table 8 , columns $B$ and $D$ ). The significance of this variable could be because of the nature of the flows. These went more to nontradable sectors, especially energy and power, financial services, and materials. Note that with the control variables used, the coefficients associated with productivity differentials and trade openness are statistically significant and have the expected sign. An increase in the productivity differential $(P R O D)$ (that is, an improvement in the tradable sector compared with other countries) will raise the demand for labor in the tradable sector, pushing up wages in nontradable sectors, resulting in real exchange rate appreciation. A shift in a country's trade policy toward greater liberalization (trade_gdp) leads to an increase in the demand for tradable goods, thereby depreciating real exchange rates.

\footnotetext{
22 When capital outflow restrictions are included, equity inflows tend to have less pressure on real exchange rate appreciation.

23 Note that debt security inflow restrictions become effective when other types of capital inflow restrictions are included.
} 


\section{Effectiveness of Capital Controls: Monetary Policy Independence}

Table 9 shows the results of the effectiveness of capital controls in fostering monetary independence. Columns $A$ and $B$ show the findings when total capital inflow and outflow restrictions are included in the model. Column $A$ shows the results when lending rates are used for measuring the monetary independence index and real exchange rate volatility is measured by a GRACH $(1,1)$ model. Column $B$ shows the findings when a standard deviation approach is applied to exchange rate volatility. Columns $C$ and $D$ show the results when capital restrictions are disaggregated by asset types (column $C$ shows the findings for capital inflow restrictions and column $D$ for outflow measurements).

The results suggest that capital inflow restrictions are effective in fostering monetary independence when a country implements a de facto pegged exchange rate regime. The coefficient of the interaction term between capital inflow controls and a pegged exchange rate is positive and significant, and the coefficient is larger than that associated with capital inflow restrictions per se (Table 9 , columns A and B). This is probably because only a fixed exchange rate regime induces a clear trade-off between capital restrictions and monetary independence. Interestingly, when capital controls are disaggregated by asset types, the results show that debt security inflow restrictions are effective in fostering monetary independence when a country implements a de facto pegged exchange rate regime. Direct investment inflow restrictions could also improve monetary policy independence, but the significance level is relatively weak (Table 9, column C). Note that the negative sign of the coefficient associated with overall capital inflow restrictions, (CRI), may be because of the ineffectiveness of capital inflow restrictions in some types of capital inflows (see the previous section). The samples also include countries using flexible exchange rate regimes - the Philippines, the Republic of Korea, and Thailand, for example-where no clear trade-off exists between capital controls and monetary policy independence.

For capital outflow controls, the estimation results, by contrast, suggest that under a fixed exchange rate regime these controls lower monetary policy independence (Table 9 , columns $A$ and $B$ ). One explanation for this result could be that in some fixed exchange rates, controls on outflows are imposed during global uncertainty to prevent capital flight, so that their effectiveness tends to be diminished. The ineffectiveness of capital outflows under fixed exchange rates is also found in other studies, including You, Kim, and Ren (2014). This possibly explains that "control on outflows are often last-minute attempts by policy makers to prevent capital flight when the economy is in deep recession" (You, Kim, and Ren 2014). When capital controls are disaggregated by asset types, the results show that both direct investment and other investment outflow restrictions lower monetary independence when exchange rates are fixed. This is shown by the negative coefficients of the interaction terms between these restrictions and fixed exchange rate regimes (Table 9, column D). Under a flexible exchange rate regime, including a managed float, capital outflow restrictions seem to help central banks gain more monetary autonomy, as reflected by the positive and significant values of coefficients associated with direct investment and other investment outflow restrictions. Consistent with the results in the previous section, it seems that the capital outflow restrictions of these two asset types could to some extent reduce capital outflows.

For the control variables, the study shows a negative and significant coefficient associated with real GDP per capita (Table 9, column A). This suggests that when a country becomes more advanced, economic integration tends to be high so that exposure to external shocks may reduce a country's monetary policy independence. High inflation reduces monetary policy independence, as shown by the negative and significant coefficient associated with inflation (Table 9, column A). This result is in line with Alesina and Summers (1993); Cukierman, Webb, and Neyapti (1992); and You, Kim, and Ren 
(2014), among other studies. The coefficient associated with real exchange rate fluctuation has a positive and significant sign. Allowing exchange rates to move freely and become shock absorbers, enables monetary policy to become more independent, especially when capital liberalization is used. Interestingly, the results suggest that trade openness, measured by the ratio of exports and imports to GDP, leads to more monetary independence (Table 9, column A). This is contrary to expectations, and may be because being open to trade tends to result in current account surpluses in emerging Asian countries, especially after the Asian financial crisis. Most countries in the region implement a de facto managed floating regime and, as a result, their foreign reserves accumulate. Huge foreign reserves could, to some extent, lead to a more independent monetary policy.

Table 9: Effectiveness of Capital Controls: Monetary Policy Independence

\begin{tabular}{|c|c|c|c|c|}
\hline & $A$ & B & $C$ & $D$ \\
\hline \multirow[t]{2}{*}{ L1.MI (lending rate) } & $-0.382^{* * *}$ & $-0.388^{* * *}$ & $-0.390^{* * *}$ & $-0.369^{* * *}$ \\
\hline & $(0.068)$ & $(0.068)$ & $(0.056)$ & $(0.077)$ \\
\hline \multirow[t]{2}{*}{ Ingdp_percapita } & $-0.341^{* * *}$ & $-0.335^{* * *}$ & $-0.537^{* * *}$ & $-0.280^{*}$ \\
\hline & $(0.104)$ & $(0.099)$ & $(0.180)$ & $(0.154)$ \\
\hline \multirow[t]{2}{*}{ Inex } & -0.124 & -0.128 & -0.196 & -0.222 \\
\hline & $(0.158)$ & $(0.161)$ & $(0.145)$ & $(0.158)$ \\
\hline \multirow[t]{2}{*}{ Instocktrade_gdp } & 0.074 & 0.073 & 0.067 & $0.100^{* *}$ \\
\hline & $(0.049)$ & $(0.050)$ & $(0.063)$ & $(0.047)$ \\
\hline \multirow[t]{2}{*}{$\ln d c_{-} g d p$} & 0.074 & 0.096 & $(-)$ & 0.154 \\
\hline & $(0.181)$ & $(0.179)$ & & $(0.263)$ \\
\hline \multirow[t]{2}{*}{$b m_{-}$reserves_gdp } & 0.023 & 0.040 & 0.045 & 0.032 \\
\hline & $(0.106)$ & $(0.112)$ & $(0.093)$ & (0.105) \\
\hline \multirow[t]{2}{*}{ CRI.Peg } & $1.926^{* * *}$ & $1.943^{* * *}$ & $(-)$ & $1.864^{* * *}$ \\
\hline & $(0.554)$ & $(0.557)$ & & $(0.610)$ \\
\hline \multirow[t]{2}{*}{ CRO.Peg } & $-1.735^{* * *}$ & $-1.726^{* * *}$ & -0.716 & $(-)$ \\
\hline & $(0.502)$ & $(0.500)$ & $(0.566)$ & \\
\hline$C R I$ & $\begin{array}{r}-1.474^{* * *} \\
(0.295)\end{array}$ & $\begin{array}{r}-1.478^{* * *} \\
(0.301)\end{array}$ & $(-)$ & $\begin{array}{r}-1.449^{* * *} \\
(0.427)\end{array}$ \\
\hline CRO & $\begin{array}{c}0.579^{* * *} \\
(0.179)\end{array}$ & $\begin{array}{c}0.612^{* * *} \\
(0.191)\end{array}$ & $\begin{array}{c}0.559^{*} \\
(0.310)\end{array}$ & $(-)$ \\
\hline \multirow[t]{2}{*}{ L1.RERvolatility } & $0.060^{* * *}$ & $(-)$ & $0.064^{* *}$ & $0.071^{* * *}$ \\
\hline & $(0.021)$ & & $(0.031)$ & $(0.021)$ \\
\hline \multirow[t]{2}{*}{ L1.RERvolatility 1} & $(-)$ & $0.064^{* * *}$ & $(-)$ & $(-)$ \\
\hline & & $(0.018)$ & & \\
\hline \multirow[t]{2}{*}{ L1.InInflation } & $-1.433^{* *}$ & $-1.504^{* *}$ & $-1.897^{* * *}$ & $-0.993^{* *}$ \\
\hline & $(0.604)$ & $(0.601)$ & $(0.706)$ & $(0.469)$ \\
\hline \multirow[t]{2}{*}{ Intrade_gdp } & $0.190^{*}$ & 0.168 & $0.296^{*}$ & $0.277^{* *}$ \\
\hline & $(0.116)$ & $(0.116)$ & $(0.184)$ & $(0.108)$ \\
\hline \multirow[t]{2}{*}{ Peg } & 0.087 & 0.076 & 0.061 & $0.166^{*}$ \\
\hline & $(0.089)$ & (0.091) & $(0.086)$ & (0.089) \\
\hline \multirow[t]{2}{*}{$C R I_{\text {direct }} \cdot P e g$} & $(-)$ & $(-)$ & 2.060 & $(-)$ \\
\hline & & & (1.333) & \\
\hline
\end{tabular}


46 | ADB Economics Working Paper Series No. 578

Table 9 continued

\begin{tabular}{|c|c|c|c|c|}
\hline & A & B & $\mathrm{C}$ & D \\
\hline$C R I_{\text {equity }} \cdot P e g$ & $(-)$ & $(-)$ & $\begin{array}{l}-3.420 \\
(2.208)\end{array}$ & $(-)$ \\
\hline$C R I_{\text {equity }} \cdot \operatorname{Peg}$ & $(-)$ & $(-)$ & $\begin{array}{c}0.691^{*} \\
(0.374)\end{array}$ & $(-)$ \\
\hline$C R I_{\text {other }} \cdot$ Peg & $(-)$ & $(-)$ & $\begin{array}{r}0.031 \\
(0.329) \\
\end{array}$ & $(-)$ \\
\hline$C R I_{\text {direct }}$ & $(-)$ & $(-)$ & $\begin{array}{r}-0.121 \\
(0.096)\end{array}$ & $(-)$ \\
\hline$C R I_{\text {equity }}$ & $(-)$ & $(-)$ & $\begin{array}{l}-0.251 \\
(0.181)\end{array}$ & $(-)$ \\
\hline$C R I_{d e b t}$ & $(-)$ & $(-)$ & $\begin{array}{r}-0.702^{* * *} \\
(0.143)\end{array}$ & $(-)$ \\
\hline$C R I_{\text {other }}$ & $(-)$ & $(-)$ & $\begin{array}{l}-0.323^{*} \\
(0.176)\end{array}$ & $(-)$ \\
\hline $\mathrm{CRO}_{\text {direct }} \cdot \mathrm{Peg}$ & $(-)$ & $(-)$ & $(-)$ & $\begin{array}{l}-1.026^{* *} \\
(0.427)\end{array}$ \\
\hline $\mathrm{CRO}_{\text {other }} \cdot \mathrm{Peg}$ & $(-)$ & $(-)$ & $(-)$ & $\begin{array}{r}-0.624^{* * *} \\
(0.218)\end{array}$ \\
\hline$C R O_{\text {direct }}$ & $(-)$ & $(-)$ & $(-)$ & $\begin{array}{l}0.156^{* *} \\
(0.069)\end{array}$ \\
\hline $\mathrm{CRO}_{\text {equity }}$ & $(-)$ & $(-)$ & $(-)$ & $\begin{array}{r}0.127 \\
(0.116)\end{array}$ \\
\hline $\mathrm{CRO}_{\text {debt }}$ & $(-)$ & $(-)$ & $(-)$ & $\begin{array}{l}-0.094 \\
(0.150)\end{array}$ \\
\hline $\mathrm{CRO}_{\text {other }}$ & $(-)$ & $(-)$ & $(-)$ & $\begin{array}{r}-1.449^{* * *} \\
(0.086)\end{array}$ \\
\hline Constant & $\begin{array}{l}3.794^{* * *} \\
(1.238)\end{array}$ & $\begin{array}{c}3.775^{* * *} \\
(1.265)\end{array}$ & $\begin{array}{l}5.654^{* *} \\
(2.460)\end{array}$ & $\begin{array}{l}3.515^{* * *} \\
(1.373)\end{array}$ \\
\hline $\begin{array}{l}\text { year } \\
\text { countries_specific }\end{array}$ & $\begin{array}{l}\text { yes } \\
\text { yes }\end{array}$ & $\begin{array}{l}\text { yes } \\
\text { yes }\end{array}$ & $\begin{array}{l}\text { yes } \\
\text { yes }\end{array}$ & $\begin{array}{l}\text { yes } \\
\text { yes }\end{array}$ \\
\hline No. of observations & 140 & 140 & 140 & 140 \\
\hline Wald chi 2 & 167.81 & 120.31 & 102.19 & 151.07 \\
\hline Prob > Chi2 & 0.000 & 0.000 & 0.000 & 0.000 \\
\hline $\operatorname{AR}(2)$ & 0.157 & 0.180 & 0.117 & 0.187 \\
\hline Sargan-Hansen test: Chi 2 & 182.871 & 184.960 & 164.349 & 160.596 \\
\hline Prob $>$ Chi 2 & 0.885 & 0.862 & 0.893 & 0.775 \\
\hline
\end{tabular}

Notes: Values in parentheses are robust standard errors. ${ }^{* *}=$ significance at $1 \%$ level, ${ }^{* *}=5 \%$, and ${ }^{*}=10 \%$. (-) refers to no presence of this variable in an estimation.

Source: Author's estimates. 


\section{CONCLUSIONS AND POLICY IMPLICATIONS}

This paper examined the effectiveness of capital account policy in terms of its ability to (i) affect the volume of capital flows; (ii) affect the composition of capital inflows toward long-term investment, especially direct investment; (iii) relieve pressures on real exchange rates; and (iv) foster monetary policy independence. Ten emerging Asian economies were used as case studies. The results show that not all capital account policies are effective in affecting capital flows. For capital inflows, restrictions on direct investment and equity inflows are effective in affecting their own capital inflows. Debt security inflow restrictions become effective only when the inflow restrictions of other asset types are included. For capital outflow restrictions, the results show that only other investment outflow restrictions reduce their own capital outflows. Asymmetric effects, in which the effect of tightening capital controls may be different from loosening these controls, are found only with equity inflow restrictions. No asymmetry is found for capital outflows.

The study finds the presence of substitution or complementarity effects in capital controls. Imposing restrictions on one type of capital affect other types of capital flows. For example, there has been complementarity between direct investment and equity inflows since the merger and acquisition mode became more important for direct investment inflows; that is, restrictions on equity inflows reduce direct investment inflows and vice versa. Restrictions on debt security inflows also potentially reduce equity inflows. In emerging Asia, the substitution or complementarity effect of capital flows as a result of capital controls is detected not only within a country but also across countries. Capital inflow deflection is evident only in direct investment inflows. Direct investment inflow restrictions in neighboring countries deflect direct investment inflows to other countries in emerging Asia. The substitution of direct investment inflows in the region could, to some extent, reflect both similar production bases regionwide and competition to attract FDI. For other asset types, inflow restrictions in neighboring countries reduce capital inflows into other countries in the region. For outflows, capital deflection is detected in equity investment, while the complementarity of outflows is found in other investment flows.

To increase the proportion of capital inflows toward FDI, economic fundamentals are more important than capital account policy. Only restrictions on debt securities are statistically significant for increasing this proportion. Economic growth, financial development, and good governance are prerequisites for being able to increase the proportion of FDI.

The results show that all types of capital inflows result in real exchange rate appreciation, but not all capital inflow restrictions help to slow the appreciation of real exchange rates; that is, only direct investment inflows and debt security restrictions help to reduce the appreciation pressures from their corresponding capital inflows. For capital outflows, the results show all types of outflows lead to a depreciation of real exchange rates, with less significance found for debt securities. Capital inflow restrictions are effective for fostering monetary policy independence when a country implements a de facto pegged exchange rate regime. Debt security inflow restrictions are effective for fostering this independence.

All in all, the study suggests that some types of capital controls are effective in creating macroeconomic stability. Capital controls, which are easier to monitor and are less involved with judgments or approvals by the authorities, are mostly found in direct investments and tend to be more effective than other types of capital controls. The choice of an exchange rate regime matters for the effectiveness of capital controls, especially for monetary policy independence. Although some types of capital controls are effective in creating macroeconomic stability, implementing 
capital account policy initiatives needs to be done with caution because of the presence of substitution or complementarity in capital flows. In emerging Asia, this not only occurs within a country but also across countries. Evidence of cross-border spillover effects points to the need for policy coordination among Asian countries to ensure macroeconomic stability within a country and within the region. However, the study shows that strong economic fundamentals are more important than capital control policy in changing the composition of capital flows for ensuring more stable and long-term flows. 


\section{REFERENCES}

Aizenman, Joshua, Menzie D. Chinn, and Hiro Ito. 2010. "The Emerging Global Financial Architecture: Tracing and Evaluating New Patterns of the Trilemma Configuration.” Journal of International Money and Finance 29 (4): 666-84.

Alesina, Alberto, and Lawrence H. Summers. 1993. "Central Bank Independence and Macroeconomic Performance: Some Comparative Evidence.” Journal of Money, Credit and Banking. 25 (2): 15162.

Arellano, Manuel, and Stephen Bond. 1991. "Some Tests for Specification of Panel Data: Monte Carlo Evidence and an Application to Employment Equations." Review of Economic Studies 58 (2): 277-97.

Ariyoshi, Akira, Karl Haberneier, Bernard Laurens, Inci Otker-Robe, Jorge Iván Canales-Kriljenko, and Andrei Kirilenko. 2000. "Capital Controls: Country Experiences with Their Use and Liberalization.” IMF Occasional Paper No. 190. Washington, DC: International Monetary Fund.

Baffes, John, Ibrahim A. Elbadawi, and Stephen A. O'Connell. 1999. "Single-Equation Estimation of the Equilibrium Real Exchange Rate." In Exchange Rate Misalignment: Concept and Measurement for Developing Countries, edited by Lawrence E. Hinkle and Peter J. Montiel. Oxford: Oxford University Press.

Bhagwati, Jagdish N. 1998. "The Capital Myth: The Difference between Trade in Widgets and Dollars." Foreign Affairs 77 (3): 7-12.

Blundell, Richard, and Stephen Bond 1998. "Initial Conditions and Moment Restrictions in Dynamic Panel Data Models.” Journal of Econometrics 87 (1): 115-43.

Bown, Chad P., and Meredith A. Crowley. 2007. "Trade Deflection and Trade Depression." Journal of International Economics 72 (1): 176-201.

Cardoso, Eliana, and Ilan Goldfajn. 1998. "Capital Flows to Brazil: The Endogeneity of Capital Controls." IMF Staff Papers 45 (1): 161-201.

Calvo, Guillermo, Leonardo Leiderman, and Carmen M. Reinhart. 1993. "Capital Flows and the Real Exchange Rate Appreciation in Latin America: The Role of External Factors." IMF Staff Papers 40 (1): 108-51.

Cukierman, Alex, Steven B. Webb, and Bilin Neyapti. 1992. "Measuring the Independence of Central Banks and Its Effect on Policy Outcomes." World Bank Economic Review 6 (3): 353-98.

Dunning, John H. 1986. "The Investment Development Cycle Revisited.” Weltwirtschaftliches Archiv $122(4): 667-75$.

Edison, Hali, and Carmen M. Reinhart. 2001. "Stopping Hot Money.” Journal of Development Economics 66 (2): 533-53. 
Edwards, Sebastian. 1989. Real Exchange Rates, Devaluation and Adjustment: Exchange Rate Policy in Developing Countries. Cambridge, MA: MIT Press.

_. 1999. "How Effective Are Capital Controls?" Journal of Economic Perspectives 13 (4): 65-84.

- 2007. "Capital Controls, Capital Flow Contractions and Macroeconomic Vulnerability." NBER Working Paper No. 12852. Cambridge, MA: National Bureau of Economic Research.

Engel, Charles. 2016. "Macroprudential Policy under High Capital Mobility: Policy Implications from an Academic Perspective." Journal of the Japanese and International Economies 42 (December): 162-72.

Fernandez-Arias, Eduardo. 1996. "The New Wave of Private Capital Inflows: Push or Pull?" Journal of Development Economics 48 (2): 389-418

Fernández, Andrés, Michael W. Klein, Alessandro Rebucci, Martin Schindler, and Martin Uribe. 2016. "Capital Control Measures: A New Dataset." IMF Economic Review 64 (3): 548-74.

Filer, II Larry H. 2004. “Large Capital Inflows to Korea: The Traditional Developing Economy Story?” Journal of Asian Economics 15 (1): 99-110.

Forbes, Kristin, Marcel Fratzscher, Thomas Kostka, and Roland Straub. 2016. "Bubble Thy Neighbor: Portfolio Effects and Externalities from Capital Controls." Journal of International Economics 99 (March): 85-104.

Forbes, Kristin, Marcel Fratzscher, and Roland Straub. 2015. "Capital Flow Management Measures: What Are They Good For?” NBER Working Paper No. 20860. Cambridge, MA: National Bureau of Economic Research.

Giordani, Paolo E., Michele Ruta, Hans Weisfeld, and Ling Zhu. 2017. “Capital Flow Deflection.” Journal of International Economics 105 (March): 102-18.

Gochoco-Bautista, Maria Socorro, Juthathip Jongwanich, and Jong-Wha Lee. 2012. "How Effective Are Capital Controls in Asia?" Asian Economic Papers 11 (2): 122-43.

Gonzalez, Celia M. 2008. "Capital Flows and Financial Assets in the Philippines: Determinants, Consequences and Challenges for the Central Bank." BIS Papers No. 44.

Hale, David D. 1998. “The Hot Money Debate.” International Economy 12 (6).

Hill, Hal, and Juthathip Jongwanich. 2009. "Outward Foreign Direct Investment and the Financial Crisis in Developing East Asia." Asian Development Review 26 (2): 1-28.

Hinkle, Lawrence E., and Peter J. Montiel. 1999. Exchange Rate Misalignment: Concept and Measurement for Developing Countries. Oxford: Oxford University Press.

International Monetary Fund (IMF). 2000-2015. Annual Report on Exchange Arrangements and Exchange Restrictions. Washington, DC. 
- - - 2017. "Increasing Resilience to Large and Volatile Capital Flows: The Role of Macroprudential Policies: Case Studies." IMF Policy Paper. Washington, DC.

Jittrapanun, Thawatchai, and Suthy Prasartset. 2009. "Hot Money and Capital Controls in Thailand." TWN Global Economy Series. No. 15. Third World Network.

Jongwanich, Juthathip. 2017. Capital Mobility in Asia: Causes and Consequences. Singapore: ISEAS, Yusof Ishak Institute.

Kim, Soyoung, and Doo Yong Yang. 2012. "Are Capital Controls Effective? The Case of the Republic of Korea.” Asian Development Review 29 (2): 96-133.

Krugman, Paul. 1999. The Return of Depression Economics. New York: Norton and Company.

Magud, Nicolas E., and Carmen Reinhart. 2007. "Capital Controls: An Evaluation." In Capital Controls and Capital Flows in Emerging Economies: Policies, Practices and Consequences, edited by Sebastian Edwards. Chicago: University of Chicago Press.

Magud, Nicolas E., Carmen M. Reinhart, and Kenneth S. Rogoff. 2011. "Capital Controls: Myth and Reality: A Portfolio Balance Approach.” NBER Working Paper No. 16805. Cambridge, MA: National Bureau of Economic Research.

McCauley, Robert. 2008. "Managing Recent Hot Money Flows in Asia.” ADBI Discussion Paper No. 99. Tokyo: Asian Development Bank Institute.

Menon, Jayant. 2009. "Managing Success in Viet Nam: Macroeconomic Consequences of Large Capital Inflows with Limited Policy Tools." Working Paper Series on Regional Economic Integration No. 27. Manila. Asian Development Bank.

Neely, Christopher J. 1999. "An Introduction to Capital Controls." Review Paper. St. Louis: Federal Reserve Bank of St. Louis.

Obstfeld, Maurice. 1994. "International Capital Mobility in the 1990s." CEPR Discussion Paper No. 902. London: Centre for Economic Policy Research.

Ostry, Jonathan D., Atish Ghosh, Karl Haberneier, Marcos Chamon, Mahvash S. Qureshi, and Dennis B.S. Reinhardt. 2010. "Capital Inflows: The Role of Controls." IMF Staff Position Note 10/04. Washington, DC: International Monetary Fund.

Rodrik, Dani. 2006. "Goodbye Washington Consensus, Hello Washington Confusion? A Review of the World Bank's Economic Growth in the 1990s: Learning from a Decade of Reforms." Journal of Economic Literature 44 (4): 619-35.

Schindler, Martin. 2009. "Measuring Financial Integration: A New Data Set.” IMF Staff Papers No. 56. Washington, DC: International Monetary Fund.

Stiglitz, Joseph E. 2002. Globalization and Its Discontents. New York: W.W. Norton. 
Tamirisa, Natalia T. 1999. "Exchange and Capital Controls as Barriers to Trade." IMF Staff Papers No. 46. Washington, DC: International Monetary Fund.

Van der Laan, Cesar R., André M. Cunha, and Marcos Tadeu C. Lélis. 2017. "On the Effectiveness of Capital Controls during the Great Recession: The Brazilian Experience 2007-2013." Journal of Post Keynesian Economics 40 (2): 203-22.

You, Yu, Yoonbai Kim, and Xiaomei Ren. 2014. "Do Capital Controls Enhance Monetary Independence?” Review of Development Economics 18 (3): 475-89. 


\section{Capital Account Policies in Emerging Asian Economies: Are they Effective in the 2000s?}

This paper examines the effectiveness of capital account policies for 10 emerging Asian economies from 2000 to 2015. The results show that some types of capital controls are effective for reducing the volume of capital flows and pressure on real exchange rates. The choice of exchange rate regime matters for the effectiveness of capital controls in fostering monetary policy independence. The study shows that strong economic fundamentals are more important than capital account policy for changing the composition of capital inflows toward more stable and long-term flows.

\section{About the Asian Development Bank}

ADB is committed to achieving a prosperous, inclusive, resilient, and sustainable Asia and the Pacific, while sustaining its efforts to eradicate extreme poverty. Established in 1966, it is owned by 68 members49 from the region. Its main instruments for helping its developing member countries are policy dialogue, loans, equity investments, guarantees, grants, and technical assistance. 